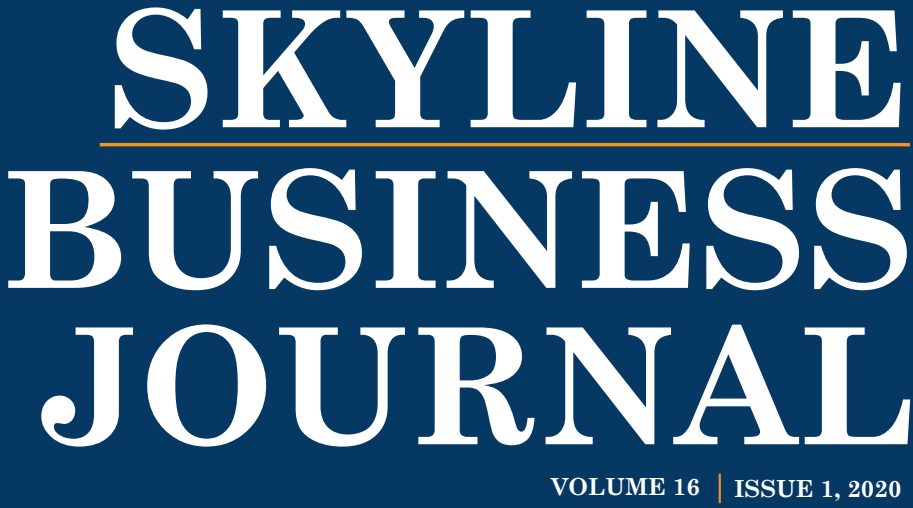

EDITORIAL

Mohammad In'airat

\title{
ARTICLES
}

MARKETING ETHICS AND COMPETITIVENESS: A STUDY OF DEPOSIT MONEY

BANK IN NIGERIA

Adetayo, Adeola E, Worimegbe, Powel M, Eze, Benneth U

ORGANIZATIONAL JUSTICE AND JOB PERFORMANCE OF ACADEMIC STAFF AT

PUBLIC UNIVERSITIES IN IRAQ

Alaa S. Jameel, Abd Rahman Ahmad, Talal S. Mousa

DETERMINANTS OF LEVERAGE: EVIDENCE BASED ON BSE LISTED INDIAN AUTO

ANCILLARY FIRMS

Animesh Bhattacharjee, Madhu Kumori, Joy Das

IMPACT OF INTERNAL AND EXTERNAL PROMOTIONAL VARIABLES ON

CONSUMER BUYING BEHAVIOR IN AN EMERGING ECONOMY - AN EMPIRICAL STUDY

Jesus Cuauhtemoc Tellez Gaytan, A. M. Sakkthivel, Shohab Sikandar Desai, Gouher Ahmed

THE NEXUS BETWEEN TAXATION AND NIGERIAN ECONOMIC GROWTH

Olufemi Samuel Adegboyo

\section{RESEARCH NOTES}

TOURISM POLICY RESEARCH AFTER THE COVID-19 PANDEMIC: RECONSIDERING

THE ROLE OF THE STATE IN TOURISM

James Kennell

ETHNIC CONFLICTS AND GEOPOLITICS: COVID-19 AUGMENTED CHAOS VERSUS

EFFORTS TO RESTART TOURISM SECTOR

S.C. Bagri, Junaid K.C.

DYNAMICS IN ACADEMICS AND CONSUMER RESEARCH IN POST-COVID-19 SCENARIO

Tejinder Sharma

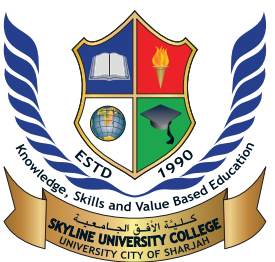

SKYLINE UNIVERSITY COLLEGE

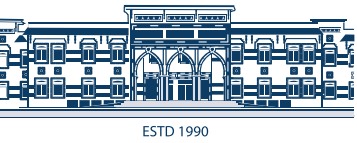




\title{
SKYLINE BUSINESS JOURNAL
}

\author{
Aims and Scope \\ Skyline Business Journal aims to publish conceptual, empirical, and applied research in the field of \\ business and management. The journal contributes new ideas and themes to the existing knowledge \\ through pragmatic investigation and theoretical analysis to advance an understanding of functioning. SBJ \\ provides an opportunity for enthusiastic researchers to publish their original work on contemporary, innova- \\ tive, and emerging themes of business and management such as finance \& accounting, marketing, supply \\ chain, human resource, and other business-related topics. The journal also publishes reviews of recently \\ released books in the Book Review Section. The aim is to encourage discussion on the ideas expressed by the \\ author/s in newly released books connected to business management and related disciplines. \\ The primary audience of the journal are academicians, researchers, and scholars from the field of business \\ management along with the practitioners. The overarching aim of SBJ is to provide meaningful insights to \\ practitioners, academicians, and scholars enabling them to draw inferences for their respective functional \\ areas.
}

\section{Publishing Agreement}

Skyline Business Journal will have the right to publish the papers in print and electronically.

Publication will be based on the following terms of publishing agreement:

A. Copyright on the article published by Skyline Business Journal is retained by the author(s).

B. The author/s shall grant to the SBJ the nonexclusive perpetual right and license to publish, archive, and make accessible their articles in whole or in part in all forms of media now or hereafter known under a Creative Commons Attribution 4.0 License.

C. The author(s) assure/s the Skyline Business Journal (as a publisher) that the material contained in the paper is not defamatory, unlawful, obscene, invasive of another person's privacy, hateful, racially or ethnically objectionable, abusive, threatening, harmful or in contempt of court, and undertake to indemnify Skyline University against any claims which may be made in situations where material is considered to be any of these things, or has any of these effects.

D. The author(s) assure/s the Skyline Business Journal that the paper presented is based entirely on original material, that it does not infringe anybody else's copyright. In the case of copyright material, such as the use of quotes or images beyond what is legally considered 'fair use', the author(s) and/or editor(s) will undertake to arrange, and if necessary to pay for, permissions, and retain documentation proving that these permissions have been secured. The author(s) agree to indemnify the Skyline Business Journal against any claims as a result of breech of the copyright of others.

Disclaimer: Skyline Business Journal contains views, thoughts, opinions, assertions and information of its contributing authors. The information expressed by these authors is not necessarily that of Skyline Business Journal or its Editorial Board. Skyline Business Journal cannot be held responsible for errors or any consequences arising from the use of information presented in this journal.

Subscription: For subscription information, please contact at sbj@skylineuniversity.ac.ae

Ethical Policy: The ethical policy of Skyline Business Journal follows the European Code of Conduct for Research Integrity. All manuscripts submitted to the Journal will be checked for plagiarism (copying material or results from other sources) and self-plagiarism (duplicating substantial parts of authors' own published work without giving the appropriate references). 


\section{SKYLINE BUSINESS JOURNAL}

\section{Patron}

Mr. Kamal Puri

Founder Chairman

\section{Editor-in-Chief}

Prof. (Dr.) Mohammad In'airat

Skyline University College, UAE
Associate Editor

Dr. Mohit Vij

Skyline University College, UAE

\section{BOARD OF ADVISORS}

\section{Mr Nitin Anand}

Vice Chairman and COEC, Skyline University College

Dr. Bob de Wit

Strategy Academy, The Netherlands

Dr. Fahim Youssofzai

Royal Military College of Canada, ON, Canada

Dr. Angappa Gunaskharan

California State University, USA

\author{
Dr. Richard Sharpley \\ University of Central Lancashire, UK \\ Dr. Devashish Das Gupta \\ IIM, Lucknow, India \\ Dr. Yam B. Limbu \\ School of Business, Montclair State University, USA \\ Prof. T. Ramayah \\ Universiti Science Malaysia (USM)
}

\section{EDITORIAL BOARD}

\section{Dr. Kristine Brands}

Regis University in Colorado Springs, USA

\section{Dr. Bella Butler}

Faculty of Business and Law, School of Management, Curtin University, Australia

Dr. Jesus Cuahtemoc Tellez Gaytan

Universidad Autonoma, del Carmen, Mexico

\section{Dr. Ming Ming Su}

Renmin University, China

Dr. Makarand Upadhyaya

Jazan University, Jazan, Saudi Arabia

Dr. G. Raju

University Of Kerala, India

Dr. J.Paul Sundar Kirubakaran

College of Applied Sciences Nizwa, Sultanate of Oman

Dr. Rajeev Sharma

Birla Institute of Management Technology, India

\section{Dr. Gouher Ahmed}

Skyline University College, UAE

Dr. Deepak Karla

Skyline University College, UAE
Dr. Kip R. Krumwiede

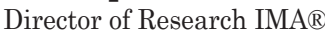

(Institute Of Management Accountants), USA

Dr. James Kennel

University Of Greenwich, UK

\section{Dr. Nicholas Meihuizen}

North West University Potchefstroom Campus, South Africa

Dr. Leszek Dziawgo

Nicholas Copernicus University, Poland

Dr. Dusan Soltes

Comenius University, Slovakia

Dr. Idorenyin Akpan

American University of Nigeria

Dr. Manish Gupta

IBS Hyderabad, India

Dr. Manuel Fernandez

Skyline University College, UAE

Dr. Ajith Kumar

Skyline University College, UAE

Dr. Ramakrishna Yanamandra

Skyline University College, UAE

Dr Paul Katuse

Skyline University College, UAE 


\section{EDITORIAL}

The year 2020 brought new challenges for the whole of mankind. The sudden outbreak of COVID-19 disrupted the way we live and work, paving the way for new norms to be defined, deliberated and practiced. The virus continues to spread uncontrollably around the world; as of 9 December 2020, 68,747,287 people have been infected globally with 1,566,690 unfortunate deaths (WHO, 2020). Many businesses were at the receiving end of the crisis, impacting the economy at a national and global level. The adverse effects of the ongoing crisis will be long lasting, challenging both the public and private sector. The World Trade Organization (WTO) has predicted that major economies will lose around 2.4 to 3.0 percent of their gross domestic product (GDP) during 2020 due to the COVID-19 pandemic. At this stage, we hope for the early arrival and availability of vaccines throughout the world to be able to go back to the normal way of living, bringing customers back to the market places and reviving the economies.

The current issue of the Skyline Business Journal is a selective collection of five articles and three research notes, addressing some of the major issues in business and management, including the recent COVID-19 challenge. The first article examines how marketing ethics (honesty, transparency, and autonomy) affect organizational competitiveness (market share) in the banking industry in Nigeria. The study recommends that the banks should place more emphasis on transparency and honesty in order to achieve and sustain organizational competitiveness and in meeting up with customers' expectations. The second article investigates the impact of organizational justice on job performance among academic staff in three public universities in Iraq. The study presents quite a few interesting recommendations on how the university academics may work effectively with their superiors. The third article investigates the impact of growth, liquidity, non-debt tax shield, profitability, size and tangibility on financial leverage with reference to the Bombay Stock Exchange listed Indian auto ancillary firms. Addressing the marketing challenges of the organizations, the fourth article investigates the impact of promotional and word-of-mouth variables on consumer buying behavior in the fast-emerging economy of the Sultanate of Oman. Article five of this issue explores the relationship between taxation and economic growth in Nigeria in the last four decades, with interesting findings and implications for the public sector, particularly in the areas of economy diversification.

This issue also presents three thought provoking research notes on COVID-19, addressing the three major areas viz. state policy and planning; ethnic conflicts and geopolitics; and education amidst COVID-19 times. In the first research note it is argued that the measures that have been taken by governments around the world in respect of their tourism industries, in response to the COVID-19 pandemic, are sufficiently significant and long-term to warrant a re-appraisal of the role of the state in tourism. The second research note elaborates on trends of global travel and the tourism sector before and during the COVID-19 pandemic, concerning the ethnic conflicts and geopolitics happening around the world. In the third and last research note, an interesting deliberation is made on the dynamics in academics and consumer research in a post-COVID-19 scenario. 
I am sure that the readers will find all the articles and research notes informative and useful. I am grateful to the entire team of the Skyline Business Journal for bringing up this excellent work. My sincere thanks and wishes to the esteemed Editorial Board members and distinguished reviewers for their support and guidance enabling us to complete this issue in a timely manner. At the end, I wish to convey my heartiest wishes to all the readers for referring to and citing the Skyline Business Journal in their academic researches and writings.

Prof. (Dr.) Mohammad In'airat,

Editor- In-Chief

Skyline Business Journal 


\title{
MARKETING ETHICS AND COMPETITIVENESS: A STUDY OF DEPOSIT MONEY BANK IN NIGERIA
}

\author{
Adetayo, Adeola E. \\ Olabisi Onabanjo University, Ago- Iwoye, Ogun State, Nigeria. \\ Email: ainaadeola59@gmail.com \\ Worimegbe, Powel M. \\ Olabisi Onabanjo University, Ago- Iwoye, Ogun State, Nigeria. \\ Email:powelmaxwell@yahoo.com
}

Eze, Benneth U.

Hallmark University, Ijebu Itele, Ogun State, Nigeria.

Email: beneze7@gmail.com

\begin{abstract}
Practicing ethics in marketing means applying standards of fairness, or moral rights and wrongs, to marketing decision making, behavior, and practice in the organization. The study seeks to examine how marketing ethics (honesty, transparency, and autonomy) affect organizational competitiveness. The survey research design was adopted to produce and present an accurate description of variables relevant to the study. Three Deposit Money Bank were selected, which are Zenith Bank Nig. Plc, First Bank Nig. Ltd and Guaranty Trust Bank Plc. The population of the three Deposit Money Bank based on their financial statements as at March 2020 is 28.3 million (First Bank, 10 million; Zenith Bank, 6.5 million and GTBank, 11.8 million). The sample size is 400 at $95 \%$ confidence level and $5 \%$ margin based on Taro Yamane formula. The primary source of data was used through a self-structured administered questionnaire to the respondents. The study employed regression in the estimation of models. Findings revealed that honesty, transparency, and autonomy have a positive, significant, and combined effect on organizational competitiveness. The study recommends that banks should take emphasis more on transparency and honesty to achieve and sustain corporate competitiveness and in meeting up with the customers' expectations.
\end{abstract}

Keywords: Marketing ethics, honesty, transparency, autonomy, and competitiveness

\section{Introduction}

One of the ways in which an organization could influence ethics is by explicitly and formally differentiating between right from wrong. Practicing ethics in marketing means applying standards of fairness and moral rights and to marketing decision making, behaviour, and practices in the organization. The purpose of marketing ethics is to create a long term sustainable competitive advantage. Organizations that develop this advantage are able to satisfy the needs of both customers and the organization.

The functional area most closely related to ethical abuse in firms is marketing. This is because marketing is the function of business charged with communicating and openly satisfying customers (Volle, 2013). Some organizations are using marketing ethics as a key selling point because more customers consider an organization's ethical reputation when making purchasing decisions. Not employing ethical marketing practices 
may lead to dissatisfied customers, bad publicity, lack of trust, lost business, or sometimes, legal action. Marketing ethics plays a critical role in forming, maintaining, and sustaining long-term customer relationships.

Customers are active in the changing business environment, i.e. economic, liberalization, increased competition, availability of more options, more emphasis on quality, etc. The issue of ethics and how it affects firms' performance has been extensively measured and established in the literature. But there is a dart of literature on the specific effects of marketing ethics on organization competitiveness. According to Klapalova (2011), competitiveness shows how the firm will be defined in the long run and how such firms will outperform its rivals.

Various studies have looked into the effect of marketing ethics on and how it affects organizational outputs. Henry and Richard (2017) opine that marketing ethics is a reliable driver of healthcare performance while Peter (2018) is of the view that marking ethics drives the performance of small and medium enterprises in the developing economy. The studies of Dincer and Dincer, (2014), Muhammad, AI Kurdi, AnuVij, and Abdallah (2016), Emad, Yoshifumi, Abdullah, and Basmanomar (2014) all point to the fact that marketing ethics could be adopted to increase organizational efficiency and performance. However, Muhammad et al., (2016) suggest that the effect of marketing ethics should be examined across all industries in order to establish its overall impact and evaluation while the study of Khairnar, (2016) suggests an empirical investigation into the interaction between marketing ethics and firms' performance. To the best of the researchers' knowledge, there is a scarcity of literature on how marketing ethics influences competitiveness in the banking sector.

In comparison, the dimensions of transparency, honesty, and autonomy have been employed in explaining marketing in existing literature (Muhaamad et al., 2016; Henry \& Richard, 2017; Abdulnasir, 2018 ). Pankaj (2019) opines that if empirically investigated, these dimensions could influence firm competitiveness and overall performance. Therefore, the kernel of this study is to examine how marketing ethics (honesty, transparency, and autonomy) affect organizational competitiveness (market share) in the banking industry. Based on the aforementioned, the following research hypotheses were formulated;

H01: Transparency do not significantly affect organizational competitiveness

H02: Honesty does not contribute significantly to organizational competitiveness H03: Autonomy does not have a positive effect on organizational competitiveness H04: Combined effect of the dimensions of marketing ethics on organizational competitiveness

\section{Literature review}

\subsection{Marketing Ethics}

Ethics generally means human conduct which may be good or bad, moral or immoral. Ethical conduct refers to the behaviour which is generally accepted by society for the right living. Behaving ethically implies doing what is morally right (Okafor, 2011; Riley, 2012). According to Abiodun and Oyeniyi (2014), ethics is based on broad principles of integrity, transparency, accountability, responsibility, and fairness, and focuses on internal stakeholder issues such as product quality, customer satisfaction, employee wages and benefits, and local community and environmental responsibilities.

Marketing ethics is described as the field applied ethics that deals with the ethical principles behind the function and regulation of marketing (Majtán \& Dubcová, 2008). Thus, ethics can be applied to each element of the marketing mix, namely, product, price, distribution, and promotion. Ferrell (2007) indicates that marketing ethics is an organizational responsibility and is essential in maintaining long-term beneficial relationships and 
establishing mutual trust with customers. Ethical marketing is not a hard and fast list of rules but a comprehensive set of guidelines to assist companies as they evaluate new marketing strategies.

Marketing ethics should be considered from an individual and organizational perspective. From the individual perspective, personal values and moral philosophies are the keys to ethical decisions in marketing. Honesty, fairness, responsibility, and citizenship are assumed to be values that can guide complex marketing decisions in the context of an organization. From an organizational perspective, organizational value, codes, and training is necessary to provide consistent and shared approaches to making ethical decisions (Ferrell, 2005).

\subsection{Elements of marketing ethics}

There are various dimensions of marketing ethics employed in different studies (Pankaj, 2019; Muhammend et al., 2016; Ferrell, 2005). However, the marketing ethics dimensions considered in this study are transparency, autonomy, and honesty. These measures, according to Abdulnasi (2018), are robust and adequately integrates the concept of ethics. Transparency according to International Bank for Reconstruction and Development (2012) opined that achieving effective business required business activities to be transparent and this necessitated access to the customer's information to increase transparency in the business transaction environment. Transparency is an attribute of corporate culture that is revealed through the behaviours of an organization's leaders, employees, and stakeholders. Honesty is a crucial characteristic of a business because it sets the tone for the kind of culture that the firm is set to create, provides consistency in workplace behaviour and builds loyalty and trust in customers and prospects. Autonomy is the consideration of the customer in the decision-making process. By considering the customers' collective opinions and recommendations, the firm is able to evaluate and determine the effects of its product and services.

\subsection{Organisational Competitiveness}

The term organizational competitiveness has been defined in the literature in different ways. Porter (2008) is of the opinion that competitiveness is the capacity of a firm to outperform its rivals in a given business environment. Lall (2001) posits that when a firm becomes a benchmark in the industry, it is said to be competitive. Depperu and Cerrato (2017) argue that competitiveness can be looked at from two perspectives, either as a driver of performance or an outcome variable. Competitiveness assumes that a company's strategy combines its internal skills with external opportunities to provide a source of sustainable competitive advantage through which it can achieve specific objectives, such as the profits generated by market share.

In the ever-evolving business environment today, agility, adaptability, flexibility and dynamic capabilities, are becoming more prominent sources of competitiveness (Bates, 2012). Depperu and Cerrato (2017) are of the opinion that the sources of competitiveness and firm performance, should be measured with quality, price, marketing, design, management and flexibility. Similarly, D' Cruz (2012) opines that firm competitiveness should be measured as the ability of the firm to produce, market, and design superior products superior to those offered by competitors in relation to both price and non-price qualities. According to Oral and Kettani (2009), measuring competitiveness in terms of market characteristics such as technology, price-quality, quantity, delivery period, design and functionality shows the degree to which the competitors and the firm strive to meet customers' expectations. These measures also show how dynamic the market is consistent. Past performance signals the existence of a 
competitive advantage, but it does not provide enough information about the sustainability of that advantage (Jayachandran \& Varadarajan, 2006).

The measure of competitiveness implies the definition of the context to which such measure is referred, as well as the level of analysis. In line with the literature, this study adopts competitiveness as an outcome that is measured by the market characteristics. The specific market attributes adopted in this study are technology and price.

\section{Theoretical Review}

\section{Normative}

The theory that underpinned this study is normative. The normative approach advocates the acceptance of a "core set of principles" or "moral maxims" to help guide marketers in ethical decision making according to Murphy, Laczniak, and Prothero, (2012). Normative marketers focus less on what organizations do and instead emphasize "what can be" i.e. what organizations ought to consider to evaluate better and improve their ethical behaviour (Laczniak \& Murphy, 2006). According to Hunt (1991), normative marketing is defined as attempting to prescribe what marketing organizations or individuals ought to do or what kinds of marketing systems a society ought to have. It is believed that normative approaches are critical because not only do they help marketers gain a better knowledge of how individuals make ethical decisions in an organization, but they also provide a vision for ethical decision making and corporate cultures within the marketing field.

Marketing Ethics and Competitiveness: The Nexus

Pankaj (2019), worked on marketing ethics: enhancing firm valuation and building competitive advantages. It is one of the organizational drivers enhancing Customer Lifetime Value (CLV). The
CLV of a customer represents the amount the customer will contribute to the bottom line of the firm over the span of the business relationship with them. Ethical marketing is practices that emphasise transparent, trustworthy, and responsible personal and organizational marketing policies and actions that exhibit integrity as well as fairness to consumers and other stakeholders. The ethical reputation of the organization results in customer trust, which in turn leads to satisfaction and commitment to the organization and hence builds competitive advantages. Research provides various marketing ethics frameworks and valuation matrix along with numerical illustrations to understand how marketing ethics helps organizations in improving overall performance and ultimately, firm valuation.

Abdulnasi (2018), appraise the marketing ethics practices of small business and their effect on consumer purchase intention: an empirical investigation from Addis Ketema Sub-city. Marketing ethics is the subset of business ethics, which deals with the systematic study of how moral standards are applied to marketing decisions, behaviours and institutions. The researcher first collected data from consumers and used both qualitative and quantitative types of research to know the effect of unethical marketing practice of cloth shops on consumers' purchase intention. In the process of collecting data, the researcher took 291 small-sized cloth shop consumers using a Time Location sampling technique. After data collection, it was analysed using descriptive statistics techniques, like tables and percentages, mean, standard deviations, graphs, frequency and logistic regression (inferential statistics). The result of this study showed that small-sized cloth shops in Addis Ketema sub-city exhibit unethical marketing practices in the area of product and price 
ethics. Additionally, it was found that consumers have purchase intention even if firms' behaviour was found to be unethical. Finally, the researcher concluded that the unethical practice of marketers might lead to consumers' lack of confidence in the market and recommended awareness programs, strengthening consumer protection act as well as the establishment of consumer associations in the area.

Peter (2018), study the ethical practices of small and medium-sized enterprises in developing countries: A literature analysis. The study aims at evaluating the aspects of business ethics, the significance of business ethics to SMEs, ethical dilemmas, and challenges of SMEs, particularly in developing countries, and suggests strategies to address ethical dilemmas and challenges. In identifying the work, peer-reviewed articles in recent journals were analysed thereof. It is clear that business enterprises can no longer afford to disregard business ethics. There are continuous business failures as a result of unethical practices, especially those associated with employees and top executives. The work has added to the body of existing literature on the ethical practices of SMEs in developing countries. As such, SME owners and managers can use the findings in the study to design ethical policy frameworks and guidelines to improve their reputations and competitiveness.

Henryand Richard (2017), work on the assessment of ethical behaviour on organizational performance in the Kenyan Public Health Sector. Ethical behaviour if not practised, has the ability to reduce organization performance which may be caused by disagreements, lawsuits, poor service delivery, poor time management, client dissatisfaction, and corruption, among others. The unethical behaviour which might affect organizational perfor- mance was measured through arrogance, absenteeism, neglect, ignorance, alcohol consumption, and smoking. The authors were opined that an organization's ability to bring forth ethical behaviour has a key asset that is difficult for competitors to imitate. The study was based on Social Learning Theory by Albert Bandura (1977), the theory posits that people learn from one another by observation, imitation, and modelling. The study was conducted in Baringo District Hospital, Kabarnet, Rift- Valley Province through a mixed approach method with a survey research design. A primary source of data was used along with a census inquiry on all the staff in the facility and 174 returned their questionnaires. Descriptive statistics and content analysis for ordinal and nominal data were used respectively. The result showed that neglect, absenteeism, poor time management, client dissatisfaction, disputes and corruption were common in the sector. It was recommended that government should support, there should training of staff, and strict enforcement of the Public Officer Ethics Act (2003) be duly implemented to curb the vices.

Khairnar (2016) examined the effect of marketing innovations and ethics. The paper takes a close look at the various ethical issues involved in marketing innovations and what organizations are doing about unethical practices. It was observed that the concept of ethics is very vague, abstract and unstructured. The definition of ethics varies, and there is no universally accepted definition because ethics is dependent on moral standards, and moral standards depend on the value system, and that value systems depend on individual background. From this, it was believed that the ethical practices of people are different. Marketing innovations strategy was measured from the marketing mix (4P's), which is seen as an important task for any marketer as they 
play a crucial role in the framing of strategies. It was concluded that successful executives are those who can effectively manage an ethical working environment, balance stakeholder value and build and maintain their personal expertise. Marketing managers must make efforts to verify that their choices and action serve the best interest of all related customers, organizations and society. It was then recommended that if an organization does the ethical practices, they will stand in the market for years with a clear image and brand name, but if otherwise, the acceptance and non- acceptance of the product is totally in the hands of the end-user.

Muhammad, AI Kurdi, AnuVij, and Abdallah (2016) study the marketing ethics and relationship marketing - an empirical study that measures the effect of ethics practices application on maintaining relationships with customers. Four elements of marketing ethics were identified in the study, which are honesty, autonomy, privacy and transparency. The study utilised a sample of 360 respondents adopting a quantitative approach; the study was conducted on telecommunication sector subscribers which revealed that the elements of marketing ethics such as feedback, transparency and privacy among others had a strong influence and affected organisation's ability to maintain long term relationships with customers. It is recommended that the result will enable marketers not only to analyse the importance of adopting ethical practices in their strategies but also to inspire the relative relevance of these practices as perceived by customers.

Emad, Yoshifumi, Abdullah, and Basmanomar (2014), study the impact of business ethics in the competitive advantage (in the Cellular Communications Companies operating in Jordan). A questionnaire was designed and administered to collect data and distribute to staff through poll views, a simple random sample of 192 staff in managerial levels such as supreme, middle and supervisors in the Cellular Communications Companies operating in Jordan. SPSS was used for data analysis. The result shows that there is a significant effect of business ethics (independence, objectivity, honesty, integrity, fairness and transparency) on competitive advantage (cost reduction, innovation and renewal) in the Cellular Communications Companies operating in Jordan.

Dincer and Dincer (2014) appraise the study on an overview and analysis of marketing ethics. In today's business world, in addition to general decisions, managers must also make judgments concerning what is ethical to do. The authors observed that is not an easy task especially for marketing professionals as marketing is the visible interface with not only customers but with all other stakeholders, it is essential for marketers to take into consideration the marketing ethics. Marketing ethics should be examined from an individual, organizational, and societal perspective.

\section{Methodology}

The study examines the effect of marketing ethics on organizational competitiveness. The survey research design was adopted to produce and present an accurate description of variables relevant to the study. Authors with similar objectives also employed this survey research design (Emad, Yoshifumi, Abdullah, and Basmanomar, 2014, Abdulnasi, 2018; Peter, 2018). For the purpose of this study, three Deposit Money Bank (DMBs) were selected, which are Zenith Bank Nig. Plc, First Bank Nig. Ltd and Guaranty Trust Bank Plc because they are the most capitalised financial institutions in Nigeria (Stock Exchange Market, 2019). 
The target overall customer population of these three Deposit Money Bank based on their financial statements as at March 2020 is 28.3 million (First Bank, 10 million; Zenith Bank, 6.5 million and GTBank, 11.8 million). Using the Taro Yammne sample size estimator, at 95\% confidence level and 5\% margin based, a sample size of 400 was arrived at. The primary source of data was used through a self- structured administered questionnaire to the respondents. Face and construct validity were employed to determine the reliability and validity of the instruments. The Cronbach alpha of $0.873,0.768,0.812$ and 0.798 was achieved for transparency, honesty, autonomy and competitiveness, respectively. The study employed linear regression to estimate the model through the aid of SPSS version 23.0.

\section{Model specification}

The model aggregates the elements of marketing ethics; it examined how these elements jointly affect the organizational competitiveness in Deposit Money Banks of Zenith Bank Nig. Plc, First Bank Nig. Ltd and Guaranty Trust Bank Plc in Nigeria. The model addresses the main objective of the study, which is to examine the effect of marketing ethics on the organizational competitiveness of DMBs in Nigeria.

The model specification is stated below:

The theory underpinning this study is the Normative Approach Theory. Hinged on the study of Oyeniyi (2014) and Klapalova (2011), it is expected that there will be a positive interaction between marketing ethics and banks' competitiveness.

Model 1

$\mathrm{OC}=\mathrm{f}(\mathrm{T})$

$\mathrm{OC}=$ B_0i+B1Ti $\left[+\mu \rrbracket \_\mathrm{i}--\cdot---(2)\right.$

Where; OC represents Organizational Competitiveness

$\mathrm{T}$ is Transparency
$B 0$ is the constant term

$B 1$ is the coefficient of the estimator.

B1>0

$\mu$ is the error term

The apriori expectation, it is expected that transparency will have a positive effect on organizational competitiveness in DMBs in Nigeria; hence the parameters of transparency should have a positive sign.

Model 2

$\mathrm{OC}=\mathrm{f}(\mathrm{H})$

$\mathrm{OC}=6 \_0 \mathrm{i}+61 \mathrm{Hi}[+\mu \rrbracket$ i---.--(4)

Where; OC represents Organizational Competitiveness

$\mathrm{H}$ isHonesty

B 0 is the constant term

$B 1$ is the coefficient of the estimator.

B1>0

$\mu$ is the error term

The A' priori expectation, it is expected that honesty will have a positive effect on organizational competitiveness in DMBs in Nigeria; hence the parameters of honesty should have a positive sign.

Model 3

$\mathrm{OC}=\mathrm{f}(\mathrm{A})$

$\mathrm{OC}=$ B_Oi+B1Ai $\left[+\mu \rrbracket \_\mathrm{i}-\mathrm{-}_{----(6)}\right.$

Where; OC represents Organizational Competitiveness

$\mathrm{A}$ is Autonomy

$B 0$ is the constant term

$B 1$ is the coefficient of the estimator.

$B 1>0$

$\mu$ is the error term

The apriori expectation, it is expected that autonomy will have a positive effect on organizational competitiveness in DMBs in Nigeria; hence the parameters of autonomy should have a positive sign.

Model 4

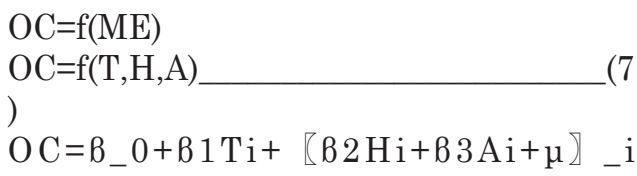

Where:

OC represents Organizational Competitiveness 
ME represents Marketing Elements $B 0$ is the constant term

$B 1, B 2$, are the coefficient of the estimator.

$B 1, B 2,>0$

$\mathrm{T}=$ Transparency

$\mathrm{H}=$ Honesty

A= Autonomy

$\mu$ is the error term

For the apriori expectation, it is expected that transparency, honesty, and autonomy will all have a positive effect on organizational competitiveness in DMBs in Nigeria; hence the parameters of transparency, honesty and autonomy should all have a positive sign.

\section{Results and Findings}

TABLE 1 HYPOTHESIS 1 TRANSPARENCY DOES NOT SIGNIFICANTLY AFFECT ORGANIZATIONAL COMPETITIVENESS.

\begin{tabular}{llllll}
\hline \multirow{2}{*}{ Variable } & B & SE & B & T-Value & P-Value \\
\hline Transparency & 0.516 & 0.022 & 0.543 & 24.682 & 0.000 \\
$\mathrm{R}^{2}$ & 0.295 & & & & \\
Collinearity & 1.314 & & & & \\
\hline
\end{tabular}

Source: Researcher's Computation, 2019

The result from table 1 reveals that there is a positive but non-significant relationship $(B=0.543)$ between transparency and competitiveness. The coefficient of determination (R2 $=0.295)$ reveals that $29.5 \%$ variation in competitiveness is explained by transparency. The unstandardised coefficient $(\mathrm{B}=0.516)$ shows that for every unit increase in transparency, competitiveness increases by 0.516 units. The $\mathrm{t}$ value (t-value $=24.682$, $\mathrm{p}=0.000$ ) establishes that transparency is a significant predictor of competitiveness. Therefore, the null hypothesis is rejected while the alternative
TABLE 2 HYPOTHESIS 2 HONESTY DOES NOT CONTRIBUTE SIGNIFICANTLY TO ORGANIZATIONAL COMPETITIVENESS.

\begin{tabular}{llllll}
\hline \multirow{2}{*}{ Variable } & $\mathrm{B}$ & $\mathrm{SE}$ & $\mathrm{B}$ & $\mathrm{T}$-Value & P-Value \\
\hline Honesty & -0.733 & 0.034 & -0.748 & 22.000 & 0.000 \\
$\mathrm{R}^{2}$ & 0.559 & & & & \\
Collinearity & 1.282 & & & & \\
\hline
\end{tabular}

Source: Researcher's Computation, 2019

The result from table 2 reveals that there is a negative but non-significant relationship $(B=-0.748)$ between honesty and competitiveness. The coefficient of determination $(\mathrm{R} 2=0.55 .9)$ reveals that $55.9 \%$ variation in competitiveness is explained by honesty. The unstandardised coefficient $(B=-0.733)$ shows that for every unity decreases in honesty, competitiveness decrease by -0.733 units. The t value $(\mathrm{t}$-value $=22.000, \quad \mathrm{p}=0.000) \quad$ establishes that honesty is a significant predictor of competitiveness. Therefore, the null hypothesis is rejected while the alternative hypothesis is accepted.

TABLE 3 HYPOTHESIS 3 AUTONOMY DOES NOT HAVE A POSITIVE EFFECT ON ORGANIZATIONAL COMPETITIVENESS.

\begin{tabular}{llllll}
\hline \multirow{2}{*}{ Variable } & $\mathrm{B}$ & $\mathrm{SE}$ & $\mathrm{B}$ & $\mathrm{T}$-Value & P-Value \\
\hline Autonomy & -0.523 & 0.041 & -0.560 & 13.652 & 0.000 \\
$\mathrm{R}^{2}$ & 0.314 & & & & \\
Collinearity & 1.311 & & & & \\
\hline
\end{tabular}

Source: Researcher's Computation, 2019

The result from table 3 reveals that there is a negative but significant relationship $(B=-0.560)$ between autonomy and competitiveness. The coefficient of determination $(\mathrm{R} 2=0.314)$ reveals that $31.4 \%$ variation in competitiveness is explained by autonomy. The unstandardised coefficient $(B=$ -0.523) shows that for every unity decrease in autonomy, competitiveness 
decreases by -0.523 units. The $t$ value $(\mathrm{t}$-value $=13.652, \mathrm{p}=0.000)$ establishes that autonomy is a significant predictor of competitiveness. Therefore, the null hypothesis is rejected while the alternative hypothesis is accepted.

TABLE 4 HYPOTHESIS 4 COMBINED EFFECT OF THE DIMENSIONS OF MARKETING ETHICS ON ORGANIZATIONAL COMPETITIVENESS

\begin{tabular}{llllll}
\hline \multirow{5}{*}{ Variable } & $\mathrm{B}$ & $\mathrm{SE}$ & $\mathrm{B}$ & $\mathrm{T}$-Value & P-Value \\
\hline Market Ethics & 0.741 & 0.028 & 0.762 & 27.214 & 0.000 \\
$\mathrm{R}^{2}$ & 0.580 & & & & \\
Collinearity & 1.281 & & & & \\
F-stat & 56.733, & & & & \\
& $\mathrm{p}=0.000$ & & & & \\
\hline
\end{tabular}

Source: Researcher's Computation, 2019

The result from table 4 reveals that there is a positive and significant relationship ( $B$ $=0.762$ ) between market ethics and competitiveness. The coefficient of determination $(\mathrm{R} 2=0.580)$ reveals that $58 \%$ variation in competitiveness is explained by market ethics. The unstandardised coefficient $(\mathrm{B}=0.741)$ shows that for every unit increase in market ethics, competitiveness increases by 0.741 units. The $\mathrm{t}$ value ( $\mathrm{t}$-value $=27.214, \mathrm{p}=0.000$ ) establishes that market ethics is a significant predictor of competitiveness. Therefore, the null hypothesis is rejected while the alternative hypothesis is accepted.

\section{Discussion of findings}

Finding reveals that transparency significantly affects organizational competitiveness in DMBs. Hence, transparency is an attribute of corporate culture that is revealed through behaviours of an organization's leaders, employees and stakeholders. Thus, organizational competitiveness in Deposit Money Banks increases because transparency contributes effectively to the ability of an organization to improve the quality of their product. The findings support the explanation of Muhammad et al. (2016) and Dincer and Dincer (2014), who established that the dimensions of marketing ethics are critical in driving organizational performance. The findings establish that transparency is a driver of competitiveness. Firms should be more transparent in nature as this has been revealed to account for higher variation in organizational competitiveness and will enable the deposit money banks to meet up with customers' expectations.

In the analysis of the second hypothesis, honesty as a measure of marketing ethics significantly affects organizational competitiveness in DMBs. Hence, honesty should be adopted as a vital characteristic of a business because it sets the tone for the kind of culture that the firm sets to create, provides consistency in workplace behaviour and builds loyalty and trust in customers and prospects. The findings corroborate the study of Khairnar, (2016), who suggests that if a firm is honest, it will operate effectively in the market both in the long and short run.

The analysis of Hypothesis 3 shows that autonomy significantly affects organizational competitiveness in DMBs, although such infect was seen to be negative. Hence it can be inferred from the study that in applying the autonomy model in the firm's operation, deposit money banks will have to take precautions. Organizational competitiveness in Deposit Money Banks decreases because autonomy contributes negatively to the ability of an organization to improve the quality of their product. The opinion and recommendations of the customers might have a negative effect on the firm's competitiveness. This position is strengthened by the works of Henry and 
Richard (2017) and Peter (2018) who are of the view that of marketing ethics dimensions are not properly evaluated, they could lead to the negative performance of organizations.

The combined effect of marketing ethics elements significantly affects competitiveness in deposit money banks. The study further revealed that ME elements have a combined adjusted coefficient of determination of 0.580 (Adj. R2= 0.580), which implied that ME elements account for $58.0 \%$ variation in the organizational competitiveness. This is consistent with the study by Emad, Yoshifumi, Abdullah, and Basmanomar, (2014); Pankaj (2019). Furthermore, Deposit Money Banks in Nigeria should adopt the normative approaches theory. This is because the findings of the study reveal that the acceptance of a core set of principles or moral maxims (transparency and honesty) will guide marketers in achieving competitiveness through an increase in their market. Marketers should be more normative in their approach as this will enhance their utilisation of ethical practices and improve their firm performance (Laczniak \& Murphy, 2006).

\section{Conclusion and recommendation}

The study examined the effect of marketing elements on organizational competitiveness in Deposit Money Banks in Nigeria. The study recognised and employed three components of marketing elements (ME) as used by various scholars. These three components are transparency, honesty and autonomy. The study employed a survey research design by administering structured questionnaires to customers of deposit money banks in Nigeria. Three hypotheses were formulated, and the ordinary least square was employed in estimating the regression models. The findings reveal that transparency is the only dimension of ethics that has a positive and significant effect on firm competitiveness in the banking industry. The results further demonstrate that honesty and autonomy have negative individual but significant impact on organizational competitiveness. The study establishes the combined effects of these elements of marketing ethics have a significant effect on competitiveness. Therefore, the study confirms that marketing ethics is a significant driver of competitiveness in the banking industry. The study recommends that deposit money banks should emphasis more on transparency and honesty in order to achieve and sustain organizational competitiveness and in meeting up with the customers' expectations. The study also suggests that organizations should correctly evaluate the components of marketing ethics, which could bring about competitiveness. This is because if marketing ethics dimensions are not adequately evaluated, they could lead to hinder the growth and competitiveness of the organization. The acceptance of core principles or moral maxims (transparency and honesty) will guide marketers in achieving competitiveness through an increase in their market share. Marketers should be more normative in their approach as this will enhance their utilisation of ethical practices and improve their firm performance.

\section{Limitations of the study and scope for further research}

The study looked into how marketing ethics affect competitiveness in the banking sector using the dimensions of transparency, honesty and autonomy in the banking sector. There is a need to expand these dimensions based on existing literature and determine their effect in other sectors while using other outcome measures of performance. This 
will increase the available literature on the concept of ethics and performance.

\section{References}

Abdulnasir, A. M. (2018). Marketing ethics practices of small businesses and their effect on consumer purchase intention: an empirical investigation from Addis Ketema Sub-city. Journal of Accounting \& Marketing, 4(2), 1-12.

Abiodun, A. J., \& Oyeniyi, O. J. (2014). Ethical dilemmas in management: An African perspective. Journal of Business Systems, Governance and Ethics, 6(2), 36-44. https://doi.org/10.15209/jbsge.v6i2.203

Bartes, F. (2012). Increasing the competitiveness of company by competitive intelligence" 7th international scientific conference, business and management, Vilnius, Lithuania, 808-814.

Depperu, B. J. \& Cerrato, I. (2017). Unbundling the construct of firm-level international competitiveness. Multinational Business Review, 19(4), 311-331.

D'Cruz, J. (2012). New Concepts for Canadian Competitiveness, Kodak, Canada.

Dincer, C. \& Dincer, B. (2014). An Overview and Analysis of Marketing Ethics. International Journal of Academic Research in Business and Social Sciences, 4(11), 151-158.

Emad, A. k., Yoshifumi, H., Abdullah, B. O. \& Basmanomar, A. (2014). The impact of business ethics in the competitive advantage in the Cellular Communications Companies operating in Jordan. European Scientific Journal, 10(10), 269-284.
Ferrell, O. C. (2005). A Framework for Understanding Organizational Ethics, in Business Ethics: New Challenges for Business Schools and Corporate Leaders. R. A. Peterson and O. C. Ferrell, (eds.) Armonk, New York: M.E. Sharpe, 3-17.

Henry, K. Y. \& Richard, M. (2017). Assessment of ethical behaviour on organisational performance. African Journal of Business Management, 11(1), 12-16.

Hunt, S. D. (1991). Modern marketing theory: Critical issues in the philosophy of marketing science. Cincinnati: South-Western Publishing Co.

Jayachandran, S. \& Varadarajan, R. (2006). Does success diminish competitive responsiveness? Reconciling conflicting perspectives. Journal of the Academy of Marketing Science, 34(3), 284-94.

Khairnar, S. D. (2016). Marketing innovations and ethics. IOSR Journal of Business and Management (IOSR-JBM), 45-48.

Klapalova, A. (2011). Competitiveness of Firms, Performance and Customer Orientation Measures; Empirical Survey Result. d. Competitiveness of firms,

Laczniak, G. R. \& Murphy, P. E. (2006). Normative perspectives for ethical and socially responsible marketing. Journal of Public Policy \& Marketing, 26(2), 154-177.

Majtán, S. \& Dubcová, G. (2008). The Ethics in the Product Marketing, output of the research projects VEGA No.1/4579/07 Diagnostic of Value Relations and Market Activities in an Enterprise and No. 1/3828/06 "NGOs -Integral Part of Economic System of the Country, Projects registered with the Grant Agency in the Slovak Republic, 1-9. 
Muhammad, A., AI Kurdi, B. H., Anu Vij, Z. O. \& Abdallah, N. (2016). Marketing ethics and relationship marketing - An empirical study that measures the effect of ethics practices application on maintaining relationships with customers. International Business Research, 9(9), 78-90.

Murphy, P. E., Laczniak, G. R. \& Prothero, A. (2012). Ethics in marketing. International cases and perspectives. New York: Routledge.

Okafor, G. O. (2011). The ethical behaviour of Nigerian business students: A study of undergraduate students in business schools. Arabian Journal of Business and Management Review,1(3), 33-44.

Oral, I. \& Kettani, O. (2009). Modelling firm competitiveness for strategy formulation. Interuniversity Research, 3(5), 1-39. Pankaj, M. M. (2019). Marketing Ethics: Enhancing FirmValuation and Building Competitive Advantages. SCMS Journal of Indian Management, A Quarterly Journal, 80-99.

Peter, K. T. (2018). Ethical practices of small and medium-sized enterprises in developing countries: A literature analysis. South African Journal of Economic and Management Sciences, 21(1), 1-7.

Riley, J. (2012). Introduction to business ethics, viewed 18 February 2013, from https:// www.tutor2u.net/business/strategy/business-ethics-introduction.html

The International Bank for Reconstruction and Development. (2012). Doing business in a more transparent world, $1-61$.

Volle, P. (2013). Le marketing peut-ilêtreresponsable? Après-Demain, 25, 1er trimestre, 10-12. 


\title{
ORGANIZATIONAL JUSTICE AND JOB PERFORMANCE OF ACADEMIC STAFF AT PUBLIC UNIVERSITIES IN IRAQ
}

\author{
Alaa S. Jameel \\ Department of Public Administration, Cihan University-Erbil, Kurdistan Region, Iraq \\ Faculty of Technology Management and Business, Universiti Tun Hussein \\ Onn Malaysia, Malaysia \\ Email: alaa.salam@cihanuniversity.edi.iq
}

\begin{abstract}
Abd Rahman Ahmad
Faculty of Technology Management and Business, Universiti Tun Hussein Onn Malaysia, Malaysia.

Email:arahman@uthm.edu.my
\end{abstract}

\section{Talal S. Mousa}

Department of Public Administration, Cihan University-Erbil, Kurdistan Region, Iraq Email: talal.mousa@cihanuniversity.edu.iq

\begin{abstract}
Job performance is one of the most critical subjects in literature due to its crucial role in the success of organizations. The purpose of this study is to examine the impact of organizational justice on job performance among academic staff. The study employed a quantitative method to analyse the data collected at three Iraqi public universities located in Baghdad by using questionnaires. Stratified sampling technique was used to ensure the equal distribution of the samples among the three universities' academic staff. Only 197 responses were valid to be analysed by using Smart PLS. The findings showed that distributive justice and interactional justice positively impacted on academic performance and ability to increase the performance, while procedural justice did not impact on academic performance. However, distributive justice had a higher impact on the job performance of academic staff compared to interactional justice. The findings of this study imply that decision-makers at universities should pay more attention to the fair distribution of resources, payment, promotion and training to increase job performance.
\end{abstract}

Keywords: Job performance, organizational justice, academic staff, distributive justice, procedural justice.

\section{Introduction}

Job performance (JP) is one of the important subjects in the literature. It becomes a primary interest to both managers and researchers due to its crucial role in the success of organizations. Therefore, it is necessary to understand the mechanisms that affect job performance, particularly among academic staff. This research attempts to expand the existing literature by offering a more detailed understanding of how organizational justice (OJ) influences JP. Many factors affect- ing JP of employees were studied previously but limited studies have examined the effect of OJ on JP among academic staff. Meanwhile, OJ remained a neglected topic in studies concerning higher education institutions. Higher education institutions are essential in any country. Education influences a country's systemic growth and development of qualified graduates because higher education is the final stage of training a young person gets before 
starting a career (Ahmad \& Jameel, 2020; Alaarj, Mohamed, \& Bustamam, 2017a, 2017b, 2016; Rabayaa \& Obaid, 2019). Academic staff at a university perform specific functions of teaching, research, supervision, publication and community service. For a country's development, these functions are significant because teaching and scientific advances in research have the capacity to build the competitive advantage of the business. Additionally, students will also have the opportunity to develop new ideas through the teaching and learning process provided by the academic staff (Abba \& Mugizi, 2018; Alaaraj, Mohamed, \& Ahmad Bustamam, 2018). These findings signify a crucial role of academic staff performance on developing a country. In further support, Colquitt et al. (2013) stressed the importance of OJ on JP as he proved the significant influence of OJ. In order to motivate organization members to optimize their success in their roles, OJ must be a central consideration of the top management. Justice promotes voluntary involvement by organization members and directly affects the organizations' and individuals' performance.

Most previous studies paid more attention to identify the impact OJ on performance appraisal (Byrne, Pitts, Wilson, \& Steiner, 2012; Massoudi, Jameel, \& Ahmad, 2020; Onuselogu \& Adaobi P., 2017; Raewf \& Thabit, 2015; Thabit Hassan Thabit \& Raewf, 2016; Tinuke, 2015), but limited studies were conducted to determine the impact of OJ on JP especially in the educational field (Arab \& Atan, 2018). The bulk of studies has been carried out in western countries on the effect of OJ on JP, while limited studies have been conducted in middle east countries (Suliman \& Kathairi, 2013;Thabit \& Raewf, 2018), particularly in Iraq (Arab \& Atan, 2018). Nevertheless, it is worth to note that western countries have a different culture compared to the middle east countries like Iraq. In parallel, $\mathrm{Li}$ and Cropanzan (2009) and Schilpzand, Martins,
Kirkman, Lowe, and Chen (2013) reported that the conceptions of justice rely on the values and standards of the local culture. The principles and rules that exist in Iraq vary to that of western countries because individualism, collectivism, or a detachment from authority or equality could be interpreted differently across cultures. Meanwhile, the procedural justice has been selected as the primary indicator of JP in most studies (Chien, Lawler, \& Uen, 2010; J. A.Colquitt, 2001; Suliman \& Kathairi, 2013; Thabit \& Jasim, 2016, 2019; Zapata-Phelan, Colquitt, Scott, \& Livingston, 2009).

University performance is primarily determined by academic staff activities such as publication, conference, research, and community service. A high percentage of these activities depends on the performance of the academicians at universities. According to Yousefi and Abdullah (2019) publication is a significant part of the work done by academic staff. The university ranking highly depends on academic productivity such as publication, conference, teaching performance, and community services performed by the academic staff of the university (Jameel \& Ahmad, 2019, 2020a). Unfortunately, Iraqi universities are suffering from low ranks compared to other regional universities (Webometric, 2020). Among the reasons for such situation is that a university ranking highly depends on academic staff performance in term of research productivity (Jameel \& Ahmad, 2020b; Mousa, Jameel, \& Ahmad, 2019), but the number of publications of Iraqi universities collected by a reliable database is only 28,091 (SJR, 2020), thus resulting in low ranks for Iraqi universities. In response, this study was conducted to measure the impact of OJ on JP of academic staff in the context of Iraq.

\section{Literature review Academic performance}

The term academic is usually associated with school, university, or any 
higher-learning institution. It involves human academic activities in a structured educational environment. Meanwhile, performance is activity, implementation, and production. Performance is referred to an accomplishment under current circumstances that subsume the mechanism of obtaining and using knowledge and skills structure and a host of successful, motivational, and stylistic factors influencing the ultimate responses (Fletcher \& Williams, 1996). Armstrong (2010) defined performance as an achievement, implementation, success, and the efficiency of anything ordered or done contributing to outputs/outcomes (accomplishment). Jameel and Ahmad (2019a) defined performance as the execution of specific tasks calculated against predetermined reliability, completeness, cost, and space requirements. Reaching the optimum level of employees' or teams' participation is a critical factor for an organisation as it helps achieve maximum organizational performance and objectives (Duyan \& Ylldız, 2018; Jameel \& Ahmad, 2019). The performance of staff is one of the most prominent variables that affect the operational sciences of the independent variables because they play an essential role in the organizational success (Al Shobaki, Abu-Naser, Amuna, \& El Talla, 2018; Jameel \& Ahmad, 2020b; Thabit, Raewf, Abdulrahman, \& Younis, 2016). The performance of a university depends on the level of academic activities, including teaching, academic publications, and social contributions (Jameel \& Ahmad, 2020; Onuselogu \& Adaobi, 2017).

Abba and Mugizi (2018) emphasized that education, research/publication, and community service were essential for the growth of any nation internationally since these roles specifically promote social welfare, financial literacy, safety and decreases crime in communities (M. A.-A. Ahmad \& Jameel, 2018; Preece, 2011). Research is one of the reasons why universities were founded, leading to new information discovery, the production of technology, enhanced service quality, increased educational prestige, and economic value. The performance of universities is mostly calculated by the efforts of academic and non-academic staff. Academic staff at a university comprised people who carry out educational work at the university, including teaching, research, and, in some instances, administrations. Therefore, educational achievements are the primary criteria used to assess a university academic performance (Jameel \& Ahmad, 2019; Onuselogu \& Adaobi P., 2017; Raewf \& Thabit, 2018). According to Abba and Mugizi (2018), Igbojekwe and Ugo-Okoro (2015), and Tinuke (2015) determinants of academic performance include staff skills, material resources, teaching, publication, research, and community service. Publication is a significant part of the work done by academic staff. High levels of organizational stressors may seem to be decreasing by publishing efforts (Jameel \& Ahmad, 2019; Yousefi \& Abdullah, 2019). However, the value of teaching performance allows higher education institutions to prepare students and provide the foundation for their potential JP. While a number of studies have measured the performance of academic staff, limited studies have been conducted in Iraqi universities. Therefore, this study attempted to fill the gap by studying the Iraqi education setting.

\section{Organizational justice}

Throughout recent years, the social justice study has attracted significant interest of scholars. Studying justice in psychology began with Adams ' dissertation on equity theory (Adams, 1963) which assumed fairness in performance. Nevertheless, considering the importance that researchers assign to justice in corporate existence, reproduction, and expansion of this research area was unavoidable. OJ captures a wide range of workplace attitudes and highlights the importance of equality and equity as a 
prerequisite for organisations to function effectively. Moreover, OJ could decrease job stress (Greenberg, 2004; Ghran, Jameel \& Ahmad, 2019; Jameel, Mahmood, \& Jwmaa, 2020). In corroboration with Karem, Mahmood, Jameel, and Ahmad (2019), and Lee, Kim, Son, and Kim (2015) OJ is a vital element in the development and maintenance of a sustainable labour environment defined as a member's sense of moral property of the way they are treated.

The early concept of OJ consisted of two dimensions namely distributive justice (DJ) and procedural justice (PJ) (Leventhal, 1980). Later, Bies and Moag (1986) proposed the third dimension of justice which was interactional justice (IJ). Greenberg (1990) categorized interactional justice into two parts; interpersonal justice and informational justice. This study focused on the main three dimensions of justice (DJ, PJ, and IJ) but IJ also covered the other two dimensions proposed by Greenberg (1990).

\section{Distributive justice}

DJ includes the allocation of incentives for work related to outputs. It is based on the theory of equity, in which expectations of unequal allocation of job incentives compared to work contributions could create tension among the employees. Distributive fairness is the degree to which the individuals in an institution perceived about the distribution of resources (Greenberg, 1990). DJ relates to the justice of particular results relative to that obtained by others (Farndale, Hope-Hailey, \& Kelliher, 2011; Jameel, Mahmood, et al., 2020; Karem et al., 2019). DJ primarily applies to the organization performance.

\section{Procedural justice}

The degree to which uniformity occurs in the Decision-Making Process (DMP) of an institution, and to what extent the views of representatives are expressed in the
DMP is known as PJ (Greenberg, 1990). PJ applies to whether DMP maintains consistency and whether beneficiaries of these judgments receive fair treatment (Byrne et al., 2012; Karem et al., 2019). The procedural justice refers to the facets of corporate transition processes. Also, PJ represents the formal expectations and performance of the communication partnerships in the DMP; PJ is distinct from IJ as it illustrates the informal connections between the DMP unit and the approving institution (Ghran et al., 2019; Jameel, Ahmad, \& Karem, 2020; Jameel, Mahmood, et al., 2020; Yu, Lee, Han, \& Kim, 2019).

\section{Interactional justice}

IJ is characterized as the degree of respect and sensitive treatment obtained by participants in an institution when decision-makers perform certain procedures that affect them (Ghran et al., 2019; Jameel, Mahmood, et al., 2020; Yu et al., 2019). IJ addresses the association between workers and the institution and the treatment on individuals (Tyler, 1989). However, IJ is often perceived as an element of PJ which refers to how one is handled during the execution of a system or policy (e.g. with respect and dignity) and stresses the interaction and social process dimensions (Bies \& Moag, 1986).

\section{Hypothesis development}

Organizational Justice and Job Performance

The universities are the only organizations centred on dual-core functions of information development and dissemination through research, teaching, and community engagement processes (Yousefi \& Abdullah, 2019). Several researchers indicated that performance and engagement at work were two significant findings related to the sense of justice (Cropanzano, Bowen, \& Gilliland, 2007; Colquitt, 2001; Zapata-Phelan et al., 
2009). Concerning the impact of DJ on employee performance, Adam's equity theory may provide the best theoretical framework established (Adams, 1963; Colquitt, 2001; Wei \& Lee, 2015). According to the equality philosophy, fairness emerges based on the proportionality of an individual's income/outcome arrangement (effort, skill, and work/prizes) relative to others. When the input/outcome level of a participant is less than the input/outcome of other participants, they will feel dissatisfied and negatively will reflect on JP. If an individual feels they are treated fairly, they would be more likely to perform and to be more comfortable in the workplace. Therefore, individuals will likely be dissatisfied and attempted to restore fairness by limiting their output and altering their quantity and quality of work (Latham \& Pinder, 2005). When individuals agree that social and mental requirements such as speech, respect, and dignity (dimensions of $\mathrm{PJ}$ and IJ) are fairly treated, it will generally result in higher performance and stronger feeling. If organisations develop high-quality communication agreements with their workers by handling them equally and allowing them to make decisions about their outcomes (fair processes), employees are more fulfilled and more likely to work to achieve a better standard of JP. Individuals are expected to show an unacceptable work performance and feel dissatisfied if they perceived that there is a low exchange relation. Therefore, JP should be correlated with substantive justice insofar as it is involved in the relationships of individuals with their employers and interactional justice insofar, as it is influenced by the relations of individuals with their superiors or supervisors (Aryee, Budhwar, \& Chen, 2002; Chien et al., 2010; Wei \& Lee, 2015).

Empirical studies have consistently shown that DJ significantly predicted JP
(Cropanzano et al., 2007; Colquitt, 2001; Shan, Ishaq, \& Shaheen, 2006). It should be remembered that according to the OJ as stated in prior studies, the workforce does not claim their organisation as fair solely based on DJ, but they will focus and examine the PJ and IJ too. However, many findings showed that PJ had a substantial impact on JP (Chien et al., 2010; Colquitt, 2001; Shan et al., 2006; Suliman \& Kathairi, 2013; Zapata-Phelan et al., 2009). Likewise, according to Masterson, Lewis, Goldman, and Taylor (2000), employees perceived PJ as having the power to increase JP and organizational engagement. Meanwhile, a limited number of studies have so far examined the effect of IJ on JP (Colquitt, 2001; Shan et al., 2006; Suliman \& Kathairi, 2013). It was expected that workers who experienced high rates of IJ would continue to show in-role JP, particularly given political facts, since they believe the superior to take care of them and that they are respected and appreciated (Tyler, 1989). The vaguest relationship lies between the presumed relationship between IJ and JP. IJ relation to JP remains unclear, and correlation experiments between these two factors produced mixed results. Some studies reported that IJ was not related and did not have an impact on JP (Colquitt, Scott, Judge, \& Shaw, 2006; Zapata-Phelan et al., 2009). However, Fernandes and Awamleh (2006) reported that the three dimensions of OJ did not have an impact on the self-perceived performance of expatriates, but some other research found a significant positive relationship (Shan et al., 2006; Suliman \& Kathairi, 2013). According to the abovementioned arguments, the study proposes the following hypotheses.

H1: Distributive justice has a positive and significant impact on Job Performance among academic staff

H2: Procedural justice has a positive and 
significant impact on Job Performance among academic staff

H3: Interactional justice has a positive and significant impact on Job Performance among academic staff

\section{Methodology}

The study employed a quantitative method to examine the impact of OJ on JP of academic staff at three Iraqi public universities located in Baghdad during the academic year 2019-2020. The data were collected by using a self-administered questionnaire and a stratified sampling technique was used to ensure equal representation of the academic staff from the three universities.

The population of the academic staff at the three universities was 476 and according to Krejcie and Morgan (1970), if the population fell in the range of 460 to 480 , the sample size should be 214 . Altogether, 198 out of 214 questionnaires returned, and after checking for missing value and incomplete responses, only 197 questionnaires were valid to be analysed by using Smart PLS which is recommended for sample size less than 200 (Chin, 2010). The questionnaire consisted of two sections. The first section contained demographic questions, and the second section included 20 items where OJ dimensions carried 15 items and JP carried 5 items. Five-point Likert scales were used from $1=$ strongly disagree to $5=$ strongly agree. Instrument

The questions were adapted from previous studies, as follows:

Job Performance: 5 items (Abba \& Mugizi, 2018; Musah et al., 2016; Shan et al., 2006)

Organizational Justice consists of three dimensions:

Distributive justice: 5 items (Lee et al., 2015; Shan et al., 2006)

Procedural justice: 5 items (Lee et al., 2015; Shan et al., 2006)

Interactional justice: 5 items (Lee et al.,
2015; Shan et al., 2006)

\section{Results}

Since the study employed the Smart PLS to analyse the data, there were two main steps conducted as per recommendation by Hair, Hult, Ringle, \& Sarstedt (2016) namely the measurement model and structural model.

\section{Information of respondents}

The majority of response is male (60\%), and followed by the female (40\%). This result is not uncommon due to the fact of culture. However, most of the respondents were between 30 to 40 years old (32\%) and followed by 41-50 years old (27\%). $20 \%$ of the respondents aged between 51-65 years old less and 12\% were more than 66 years old. Lastly, $8 \%$ of the respondents were less than 29 years old. The qualifications showed that $55 \%$ of the academic staff possessed a Ph.D., and 45\% graduated from a Master's degree. Finally, regarding the academic position, $37 \%$ of the respondents were Assistant Professor and followed by $32 \%$ Assistant Lecturer. Meanwhile, $14 \%$ of them were in the Lecturer position and only $17 \%$ were professors.

\section{Model measurement}

The purpose of this step is to measure the validity, reliability, and discriminations of the items. To ensure these requirements, the convergent validity and discrimination validity were tested.

Convergent Validity consists of three tests. The first one is the average variance extracted (AVE) which reflects the total amount of variation in the indicators of the latent construct. The second one is the composite reliability (CR) and Cronbach's Alpha is preferred to ensure the internal consistency among items. The third one is factor loadings.

The cutoff values for acceptable CR and 
Cronbach's Alpha should be 0.70 or above

TABLE 1. CONVERGENT VALIDITY

\begin{tabular}{|c|c|c|c|c|c|}
\hline Constructs & Items & $\begin{array}{c}\text { Outer } \\
\text { loadings }\end{array}$ & $\begin{array}{l}\text { Cronbach's } \\
\text { Alpha }>0.7\end{array}$ & $\mathrm{CR}>0.7$ & $(\mathrm{AVE})>0.5$ \\
\hline $\begin{array}{c}\text { Job } \\
\text { Performance }\end{array}$ & $\begin{array}{l}\text { JP1 } \\
\text { JP2 } \\
\text { JP3 } \\
\text { JP4 } \\
\text { JP5 }\end{array}$ & $\begin{array}{l}0.805 \\
0.880 \\
0.904 \\
0.876 \\
0.797\end{array}$ & 0.906 & 0.930 & 0.728 \\
\hline $\begin{array}{c}\text { Distributive } \\
\text { Justice }\end{array}$ & $\begin{array}{l}\text { DJ1 } \\
\text { DJ2 } \\
\text { DJ3 } \\
\text { DJ4 } \\
\text { DJ5 }\end{array}$ & $\begin{array}{l}0.834 \\
0.894 \\
0.903 \\
0.773 \\
0.784\end{array}$ & 0.895 & 0.922 & 0.705 \\
\hline $\begin{array}{c}\text { Interactional } \\
\text { Justice }\end{array}$ & $\begin{array}{l}\text { IJ1 } \\
\text { IJ2 } \\
\text { IJ3 } \\
\text { IJ4 } \\
\text { IJ5 } \\
\end{array}$ & $\begin{array}{l}0.858 \\
0.896 \\
0.902 \\
0.838 \\
0.802\end{array}$ & 0.912 & 0.934 & 0.740 \\
\hline $\begin{array}{c}\text { Procedural } \\
\text { Justice }\end{array}$ & $\begin{array}{l}\mathrm{PJ} 1 \\
\mathrm{PJ} 2 \\
\mathrm{PJ} 3 \\
\mathrm{PJ} 4 \\
\mathrm{PJ} 5\end{array}$ & $\begin{array}{l}0.844 \\
0.875 \\
0.909 \\
0.874 \\
0.762\end{array}$ & 0.907 & 0.931 & 0.730 \\
\hline
\end{tabular}

TABLE 2 FORNELL-LARCKER CRITERION DISCRIMINANT VALIDITY

\begin{tabular}{|c|c|c|c|c|}
\hline constructs & $\begin{array}{c}\text { Distributive } \\
\text { Justice }\end{array}$ & $\begin{array}{c}\text { Interactional } \\
\text { Justice }\end{array}$ & $\begin{array}{c}\text { Job } \\
\text { Performance }\end{array}$ & $\begin{array}{c}\text { Procedural } \\
\text { Justice }\end{array}$ \\
\hline Distributive Justice & $\mathbf{0 . 8 3 9}$ & & & \\
\hline Interactional Justice & 0.573 & $\mathbf{0 . 8 6}$ & & \\
\hline Job Performance & 0.545 & 0.496 & $\mathbf{0 . 8 5 3}$ & \\
\hline Procedural Justice & 0.325 & 0.476 & 0.363 & $\mathbf{0 . 8 5 4}$ \\
\hline
\end{tabular}

(Hair et al., 2016), while AVE should be 0.50 or above (Hair et al., 2016). Factor loadings should be $>0.70$ (Hair et al., 2016).

The results of $\mathrm{CR}$ and Alpha exceeded the recommended level 0.70 with high internal consistency. Similarly, AVE > 0.50 (see Table 1). All items loading exceeded the recommended level 0.70 as shown in Figure 1 and Table 1 depicted the factor loading values.

\section{Discriminant validity}

Our study employed two criteria to assess discriminant validity. The first one is the
Fornell-Larcker Criterion whereas the second one is the cross-loadings. All discrimination results met the acceptable level.

The boldface values in Table 2 showed each factor that was highly correlated with itself than others and this criterion was achieved as essential for validity discrimination. Second, cross-loading for each item in the same factor should have a high correlation among themselves, and this criterion is achieved and illustrated in bold font (see Table 3). Overall, each factor in this study had a high square root of AVE compared to other factors (Fornell 
\& Larcker, 1981).

\section{Structural model}

This study proposed three hypotheses to be tested. Therefore, this study performed
(2016), this value is considered medium.

DJ (Path coefficient $=0.377$, T- Statistics $4.749>1.96$ and $\mathrm{P}$-value $<0.05$ ) and IJ (Path coefficient $=0.215, \mathrm{~T}$ - Statistics

TABLE 3 CROSS LOADING

\begin{tabular}{|c|c|c|c|c|}
\hline constructs & DJ & IJ & JP & PJ \\
\hline DJ1 & $\mathbf{0 . 8 3 4}$ & 0.432 & 0.458 & 0.229 \\
\hline DJ2 & $\mathbf{0 . 8 9 4}$ & 0.53 & 0.462 & 0.254 \\
\hline DJ3 & $\mathbf{0 . 9 0 3}$ & 0.493 & 0.426 & 0.294 \\
\hline DJ4 & $\mathbf{0 . 7 7 3}$ & 0.485 & 0.366 & 0.274 \\
\hline DJ5 & $\mathbf{0 . 7 8 4}$ & 0.465 & 0.536 & 0.307 \\
\hline IJ1 & 0.601 & $\mathbf{0 . 8 5 8}$ & 0.428 & 0.414 \\
\hline IJ2 & 0.492 & $\mathbf{0 . 8 9 6}$ & 0.443 & 0.415 \\
\hline IJ3 & 0.463 & $\mathbf{0 . 9 0 2}$ & 0.424 & 0.401 \\
\hline IJ4 & 0.467 & $\mathbf{0 . 8 3 8}$ & 0.451 & 0.477 \\
\hline IJ5 & 0.439 & $\mathbf{0 . 8 0 2}$ & 0.383 & 0.331 \\
\hline JP1 & 0.478 & 0.492 & $\mathbf{0 . 8 0 5}$ & 0.336 \\
\hline JP2 & 0.483 & 0.403 & $\mathbf{0 . 8 8}$ & 0.297 \\
\hline JP3 & 0.494 & 0.484 & $\mathbf{0 . 9 0 4}$ & 0.338 \\
\hline JP4 & 0.422 & 0.425 & $\mathbf{0 . 8 7 6}$ & 0.278 \\
\hline JP5 & 0.438 & 0.285 & $\mathbf{0 . 7 9 7}$ & 0.289 \\
\hline PJ1 & 0.246 & 0.392 & 0.315 & $\mathbf{0 . 8 4 4}$ \\
\hline PJ2 & 0.182 & 0.386 & 0.264 & $\mathbf{0 . 8 7 5}$ \\
\hline PJ3 & 0.306 & 0.465 & 0.303 & $\mathbf{0 . 9 0 9}$ \\
\hline PJ4 & 0.317 & 0.449 & 0.34 & $\mathbf{0 . 8 7 4}$ \\
\hline PJ5 & 0.317 & 0.333 & 0.313 & $\mathbf{0 . 7 6 2}$ \\
\hline & & & & \\
\hline
\end{tabular}

bootstrapping with 5,000 subsamples while the error estimated 0.05 and the confidence .95 and the T-Statistics should be above 1.96 to accept the hypothesis (Hair et al., 2016). The results showed two of three hypotheses were accepted.

The R2 (the coefficient of determination) of this study is 0.362 (see Figure 1) and this means $36 \%$ of the variation in JP was explained by OJ. According to Hair et al.
$2.247>1.96$ and $\mathrm{P}$-value $<0.05$ ) were significantly related to JP. Therefore, $\mathrm{H} 1$ and H3 were accepted. This result is in line with previous findings (Shan, Ishaq, \& Shaheen, 2006; Shan et al., 2006; Suliman \& Kathairi, 2013).

PJ (Path coefficient $=0.138$, T- Statistics $1.840<1.96$ and $\mathrm{P}$-value $0.066>0.05$ ) was insignificantly related to JP. Thus, H2 was rejected. A similar finding was report- 
ed by Fernandes \& Awamleh, 2006). The context. Conversely, Procedural justice results are shown in Table 4 and Figure 1.

TABLE 4. PATH ASSESSMENT

\begin{tabular}{|l|c|c|c|c|}
\hline \multicolumn{1}{|c|}{ Hypotheses } & $\begin{array}{c}\text { Path } \\
\text { coefficient }\end{array}$ & T-Statistics & P-Values & Remark \\
\hline Distributive Justice -> Job Performance & 0.377 & 4.746 & 0.00 & Accepted \\
\hline Procedural Justice -> Job Performance & 0.138 & 1.840 & 0.066 & Rejected \\
\hline Interactional Justice -> Job Performance & 0.215 & 2.247 & 0.025 & Accepted \\
\hline
\end{tabular}

$\mathrm{R} 2=0.362 \mathrm{Q} 2=0.247$

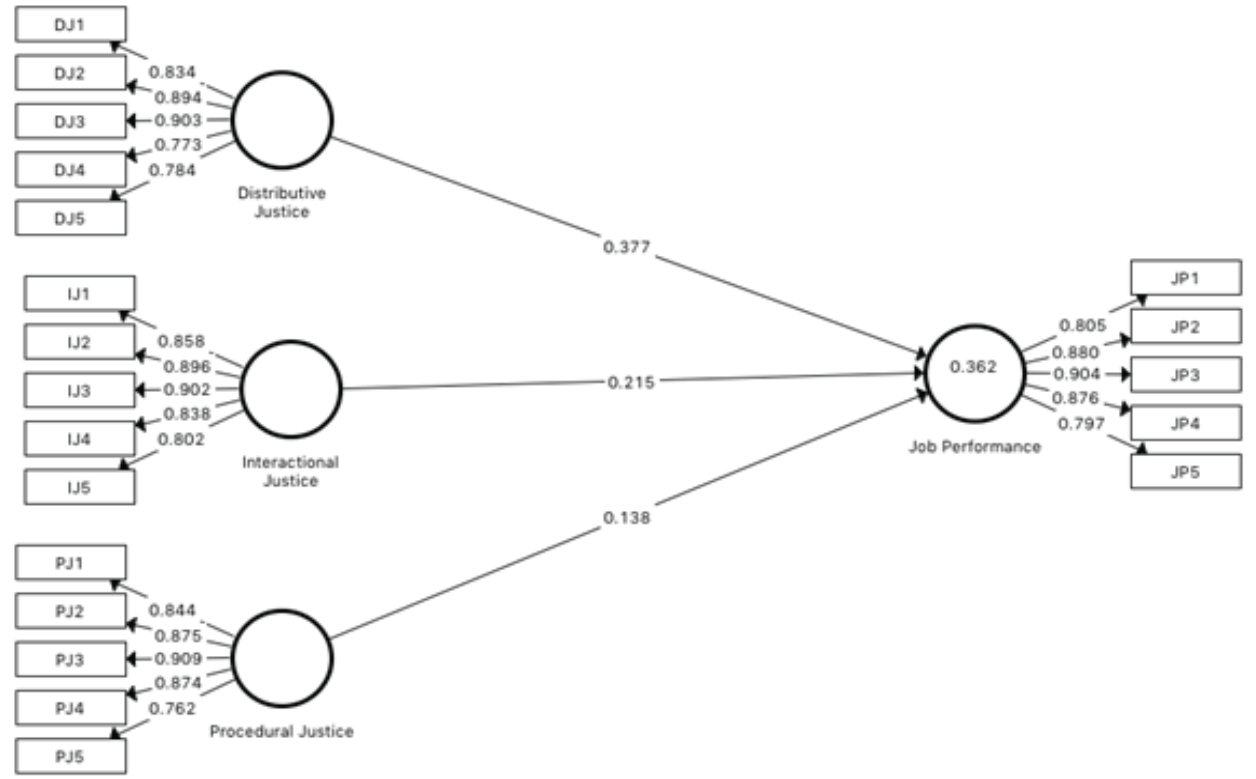

Figure 1. Structural Model

\section{Discussion}

The purpose of this study is to explore the role of Organizational Justice among academic staff at Iraqi public universities. Previous studies found inconsistent findings about the impact of Organizational Justice on Job Performance from both a positive and a negative perspective. Concerning the major impact of the elements of Organizational Justice, this paper concluded that Distributive justice and Interactional justice had significant and substantial contributions to the Job Performance of academic staff in the Iraqi had an insignificant impact on Job Performance probably due to the universities and government policies.

Distributive justice showed a high prediction on the Job Performance of the academic staff compared to IJ. The impact of Distributive justice on Job Performance is in line with prior studies (Shan et al., 2006; Suliman \& Kathairi, 2013; Ghran et al., 2019). This means the academic staff who received equal rewards were most likely to perform well at the university. The analysis of the data showed that 
academics regard their time, workload, and salary level as equal. The reality is that the Iraqi public universities considered in this study followed the government-organization pay structure with fair pay for staff (academics/non-academics). However, Distributive justice centres on fairness allocation of wealth which includes wages, service expenses, and job security. Distributive justice may as well include other services such as office rooms, furnishings, travel support, and test rooms.

Procedural justice did not have significant impact on the Job Performance of the academic staff (P-Value $0.066>0.05$ and T-statistics 1.840) which led to the rejection of the second hypothesis. This result is supported by the previous finding by Fernandes and Awamleh (2006). JP tends not to be linked to the conceptions of Procedural justice. This finding undermines in extensive part conventional study findings in this area, which typically suggest and show substantial positive ties between all facets of justice and success. In other words, expectations of justice affect or change the behaviour of people who continuously seek to restore justice by different means. However, procedural justice does not impact on Job Performance of the academic staff perhaps because the study was conducted in public universities, and it is understood that their continuing employment and career progress are dependent directly on government programs and policies and not on the universities itself.

H3 confirmed the impact of Interactional justice on Job Performance of the academic staff with T-statistics $2.247>1.96$ and $\mathrm{P}$ value $0.028<0.05$. A similar result was reported by earlier studies (Shan et al., 2006; Suliman \& Kathairi, 2013; Ghran et al., 2019). Most academic staff acknowl- edged that their Head of Department or Dean had provided them with adequate justification for the employment decision. For Interactional justice, the academic staff was asked whether or not their Head of Department or Dean treated them equally and most respondents thought that their Head of Department or Dean had treated them with respect, honesty, compassion, and truthfulness. Such results indicate that, while results of the study vary in relation to the relative essential of each element of justice in link to each result compared with studies conducted in non -middle east countries, the understanding of the three aspects of the justice system influences an employee's patterns to react in order to achieve better performance in their work. Since the value of injustice is universal, former academics have indicated that judicial views on different work results continue to vary in cultural and national contexts (Schilpzand et al., 2013). The results summarized here suggest that academic staff attribute a higher value to interpersonal interactions obtained through processes and outcome decision-making by their Head of Department or Dean at university. Furthermore, the findings showed that assistance, integrity, respect, and consideration were the main reasons for achieving high-performance and comfortable employees.

Implications

The theoretical implication of this study is enriching the body of knowledge in the context of Iraq and academic context in developing countries. The study confirmed that the theory of OJ was applicable in the context of higher education. However, the practical implication indicated that DJ was more important to improve the academic staff performance. Besides, the Head of Department and the Dean are advised to enhance the DJ, where they 
should equitably distribute the resource among academic staff. The IJ was shown to be important for academic staff, thus the Head of Department and the Dean should deal with academic staff with complete honesty and dignity.

Conclusion, Limitations, and Future work

The current study specifically addressed the academic staff's understanding of OJ and the performance of their interaction with their superiors (Head of Department / Dean). The study focused on academic performance's soft side to improve productive and useful behaviour. The results show that university academics work effectively with their superiors (Head of Department / Dean). To ensure equality at universities, the current Head of Department / Dean must uphold the moral and ethical code of conduct by including all participants in the DMP. In addition, to ensure equality in the allocation of incentives and processes involved in the decision-making of recruitment, selection, training and development, and assessment of JP, it is equally necessary to ensure fairness in interpersonal interaction between the Head of Department / Dean and the academic staff. When academic staff perceived the Head of Department / Dean as being professional, trustworthy, real, and justifiable, they feel more confident and optimistic.

This study, like any other study, has several limitations. The study was conducted only in three universities located in Baghdad due to security issues and the inability to carry out research in more than those three universities. The study was conducted in public universities only, hence the results could not be generalized the result to private universities due to the difference in the nature of rules and regulations. Future studies can be conducted in more than three universities and cover private universities as well. The prospective study may examine the causal effect of OJ on JP by examining the mediating role.

\section{References}

Abba, H. D., \& Mugizi, W. (2018). Performance of academic staff in polytechnics: an analysis of performance levels in the Northwest geopolitical zone of Nigeria. Arts \& Humanities Open Access Journal, 2(3). https://doi.org/10.15406/ahoaj.2018.02.00056

Adams, J. S. (1963). Towards an understanding of inequity. Journal of Abnormal and Social Psychology, 67(5), 422-436. https://doi.org/10.1037/h0040968

Ahmad, A. R., \& Jameel, A. S. (2020). Job Satisfaction as a Mediator between Transformational Leadership and Organizational Citizenship Behaviours. International Journal of Advanced Science and Technology, 29(5), 10163-10174. Retrieved from http://sersc.org/journals/index.php/IJAST/article/view/19507

Ahmad, M. A.-A., \& Jameel, A. S. (2018). Factors Affecting on Job Satisfaction among Academic Staff. Polytechnic Journal, 8(2), 119-128. https://doi.org/https://doi.org/10.25156/ptj.2018.8.2.161

Al Shobaki, M. J., Abu-Naser, S. S., Amuna, Y. M. A., \& El Talla, S. A. (2018). Support Extent Provided by Universities Senior Management in Assisting the Transition to e-Management. International Journal of Academic Management Science Research (IJAMSR), 2(5).

Alaaraj, S., Mohamed, Z. A., \& Ahmad Bustamam, U. S. (2018). External growth strategies and organizational performance in emerging markets: The mediat- 
ing role of inter-organizational trust. Review of International Business and Strategy, 28(2), 206-222. https://doi.org/10.1108/RIBS-09-2017-0079

Alaarj, S., Mohamed, Z. A., \& Bustamam, U. S. A. (2017a). Do knowledge management capabilities reduce the negative effect of environment uncertainties on organizational performance? A study of public listed companies in Malaysia. International Journal of Economic Research, 14(15), 443-456.

Alaarj, S., Mohamed, Z. A., \& Bustamam, U. S. A. (2017b). The effect knowledge management capabilities on performance of companies: A study of service sector. International Journal of Economic Research, 14(15), 457-470.

Alaarj, S., Mohamed, Z. A., \& Bustamam, U. S. B. A. (2016). Mediating Role of Trust on the Effects of Knowledge Management Capabilities on Organizational Performance. Procedia - Social and Behavioral Sciences, 235(2016), 729-738. https://doi.org/10.1016/j.sbspro.2016.11.074

Arab, H. R., \& Atan, T. (2018). Organizational justice and work outcomes in the Kurdistan Region of Iraq. Management Decision, 56(4), 808-827. https://doi.org/10.1108/MD-04-2017-0405

Aryee, S., Budhwar, P. S., \& Chen, Z. X. (2002). Trust as a mediator of the relationship between organizational justice and work outcomes: Test of a social exchange model. Journal of Organizational Behavior, 23(3), 267-285. https://doi.org/10.1002/job.138

Bies, R. J., \& Moag, J. S. (1986). Interactional justice: communication criteria of fairness. In Research in negotiations in organizations (pp. 43-55). https://-

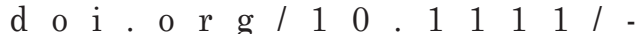
j.1559-1816.2004.tb02581.x

Byrne, Z. S., Pitts, V. E., Wilson, C. M., \& Steiner, Z. J. (2012). Trusting the fair supervisor: The role of supervisory support in performance appraisals. Human Resource Management Journal, 22(2), 129-147. https://doi.org/10.1111/j.1748-8583.2012.00193.x

Chien, M. S., Lawler, J. S., \& Uen, J. F. (2010). Performance-based pay, procedural justice, and job performance for R\&D professionals: Evidence from the Taiwanese high-tech sector. International Journal of Human Resource Management, 21(12), 2234-2248. https://doi.org/10.1080/09585192.2010.509626

Chin, W. W. (2010). How to write up and report PLS analyses. Handbook of Partial Least Squares: Concepts, Methods and Applications, VE Vinzi, WW Chin, J. Henseler, and H. Wang. New York: Springer.

Colquitt, J. A., Scott, B. A., Judge, T. A., \& Shaw, J. C. (2006). Justice and personality: Using integrative theories to derive moderators of justice effects. Organizational Behavior and Human Decision Processes, 100(1), 110-127. https://doi.org/10.1016/j.obhdp.2005.09.001

Colquitt, J. A., Scott, B. A., Rodell, J. B., Long, D. M., Zapata, C. P., Conlon, D. E., \& Wesson, M. J. (2013). Justice at the millennium, a decade later: A meta-analytic test of social exchange and affect-based perspectives. Journal of Applied Psychology, 98(2), 199-236. https://doi.org/10.1037/a0031757

Cropanzano, R., Bowen, D. E., \& Gilliland, S. W. (2007). The management of organizational justice. Academy of Management 
Perspectives, 21(4), 34-48. https://doi.org/10.5465/AMP.2007.27895338

Duyan, M., \& Ylldız, S. M. (2018). The effect of leader-member exchange on job performance of academic staff: An empirical evidence from higher education institutions. Journal of Human Sciences, 15(2), 1129.

jhs.v15i2.5162

Farndale, E., Hope-Hailey, V., \& Kelliher, C. (2011). High commitment performance management: The roles of justice and trust. Personnel Review, 40(1), 5-23. $\mathrm{h} \quad \mathrm{t} \quad \mathrm{t} \quad \mathrm{p} \quad \mathrm{s}$ : / / . doi.org/10.1108/00483481111095492

Fernandes, C., \& Awamleh, R. (2006). Impact of organisational justice in an expatriate work environment. Management Research News, 29(11), 701-712. $\mathrm{h} \quad \mathrm{t} \quad \mathrm{t} \quad \mathrm{p} \quad \mathrm{s}$ : / / . doi.org/10.1108/01409170610716016

Fletcher, C., \& Williams, R. (1996). Performance management, job satisfaction, and organizational commitment. British Journal of Management, 7(2), 169-179. h t t p s : // d o i . org/ 10.1111 / j.1467-8551.1996.tb00112.x

Fornell, C., \& Larcker, D. F. (1981). Evaluating Structural Equation Models with Unobservable Variables and Measurement Error. Journal of Marketing Research, 18(1), 39. https://doi.org/10.2307/3151312

Ghran, L. A. Z., Jameel, A. S., \& Ahmad, A. R. (2019). The effect of organizational justice on job satisfaction among secondary school teachers. International Review, 3(3-4), 82-90. https://doi.org/10.5937/intrev1903082L

Greenberg, J. (1990). Organizational Justice: Yesterday, Today, and Tomorrow.
Journal of Management, 16(2), 399-432. $\mathrm{h} \quad \mathrm{t} \quad \mathrm{t} \quad \mathrm{p} \quad \mathrm{s}$ : / / . doi.org/10.1177/014920639001600208

Greenberg, J. (2004). Stress fairness to fare no stress: Managing workplace stress by promoting organizational justice. Organizational Dynamics, 33(4 SPEC.ISS.), 352-365. https://doi.org/10.1016/j.orgdyn.2004.09.003

Hair, Hult, T. M., Ringle, C. M., \& Sarstedt, M. (2016). A primer on partial least squares structural equation modeling (PLS-SEM). Sage Publications.

Igbojekwe, P., \& Ugo-Okoro, C. P. (2015). Performance Evaluation of Academic Staff in Universities and Colleges In Nigeria: The Missing Criteria. International Journal of Education and Research, 3(3), 627-640.

J. A.Colquitt. (2001). On the dimensionality of organizational justice: A construct validation of a measure. Journal of Applied Psychology, 68(3), 386-399.

Jameel, A. S., \& Ahmad, A. R. (2019). Leadership and Performance of Academic Staff in Developing Countries. The 33rd International Business Information Management Association Conference, 6101-6106. Granada, Spain: IBIMA.

Jameel, A. S., \& Ahmad, A. R. (2020a). Factors Impacting Research Productivity of Academic Staff at the Iraqi Higher Education system. International Business Education Journal, 13(1), 108-126. Retrieved from http://ejournal.upsi.edu.my/index.ph p/IBEJ/arti cle/view/3568

Jameel, A. S., \& Ahmad, A. R. (2020b). The Mediating Role of Job Satisfaction between Leadership Style and Perfor- 
mance of Academic Staff. International Journal of Psychosocial Rehabilitation, 24(04), 2399-2414. https://doi.org/10.37200/IJPR/V24I4/PR201349

Jameel, A. S., Ahmad, A. R., \& Karem, M. A. (2020). Organizational Justice and Performance among academic staff. In K. S. Soliman (Ed.), Proceedings of the 35th International Business Information Management Association Conference, IBIMA 2020: Education Excellence and Innovation Management: A 2025 Vision to Sustain Economic Development during Global Challenges (pp. 17871-17877). Seville, Spain.

Jameel, A. S., Mahmood, Y. N., \& Jwmaa, S. J. (2020). Organizational Justice and Organizational Commitment among Secondary School teachers. Cihan University-Erbil Journal of Humanities and Social Sciences, 4(1), 1-6. https://d o i . o r g / 10 . $24086 / \mathrm{c} \mathrm{u} \mathrm{e} \mathrm{-}$ jhss.vol4n1y2020.pp1-7

Karem, M. A., Mahmood, Y. N., Jameel, A. S., \& Ahmad, A. R. (2019). The Effect of Job Satisfaction and Organizational Commitment on Nurses' Performance. Humanities and Social Sciences Reviews, 7(6), 332-339. https://doi.org/10.18510/hssr.2019.7658

Krejcie, R. V, \& Morgan, D. W. (1970). Determining Sample Size For Research Activities, Educational And Psychological Measurement. EDUCATIONAL AND PSYCHOLOGICAL MEASUREMENT, (30), 607-610.

Latham, G. P., \& Pinder, C. C. (2005). Work Motivation Theory and Research at the Dawn of the Twenty-First Century. Annual Review of Psychology, 56(1), 485-516. https://doi.org/10.1146/annurev.psych.55.090902.142105
Lee, Y. K., Kim, S., Son, M. H., \& Kim, M. S. (2015). Linking Organizational Justice to Job Performance: Evidence from the Restaurant Industry in East Asia. Asia Pacific Journal of Tourism Research, 20(June), 1527-1544. https://doi.org/10.1080/10941665.2015.1016052

Li, A., \& Cropanzano, R. (2009). Do east Asians respond more/less strongly to organizational justice than North Americans? A meta-analysis. Journal of Management Studies, 46(5), 787-805. https://doi.org/10.1111/j.1467-6486.2009.00825.x

Massoudi, A. H., Jameel, A. S., \& Ahmad, A. R. (2020). Stimulating Organizational Citizenship Behavior by Applying Organizational Commitment and Satisfaction. International Journal of Social Sciences and Economic Review, 02(02), 20-27. https://doi.org/10.36923/ijsser.v2i2.58

Masterson, S. S., Lewis, K., Goldman, B. M., \& Taylor, M. S. (2000). Integrating Justice and Social Exchange: The Differing Effects of Fair Procedures and Treatment on Work Relationships. Academy of Management Journal, 43(4), 738-748. https://doi.org/10.5465/1556364

Mousa, T. S., Jameel, A. S., \& Ahmad, A. R. (2019). The Impact of Attitude, Subjective Norm and Information Communications Technology on Knowledge Sharing among Academic Staff. International Journal of Psychosocial Rehabilitation, 23(02), 704-717.

Musah, M. B., Ali, H. M., Vazhathodi al-Hudawi, S. H., Tahir, L. M., Daud, K. B., Said, H. Bin, \& Kamil, N. M. (2016). Organisational climate as a predictor of workforce performance in the Malaysian higher education institutions. Quality Assurance in Education, 24(3), 416-438. 
https://doi.org/10.1108/QAE-10-2014-0048 Onuselogu, \& Adaobi P. (2017). Effect of academic staff promotional appraisal measures on academic performance of universities in Anambra state. Online Journal of Arts, Management and Social Sciences, 2(3), 64-73.

Preece, J. (2011). Higher Education and Community Service: Developing the National University of Lesotho's Third Mission. Journal of Adult and Continuing Education, 17(1), 81-97. https://doi.org/10.7227/jace.17.1.7

Rabayaa, S. M., \& Obaid, S. M. (2019). The Impact of Knowledge Management by Technological Tools and Electronic-means on Academic Staff Performance in Palestinian Universities. International Review of Management and Marketing, 9(2), 57-63.

doi.org/10.32479/irmm.7656

Raewf, M. B., \& Thabit, T. H. (2015). The Student's Satisfaction Influential Factors at Cihan University. International Journal Of Advanced Research in Engineering \& Management (IJAREM) |, 01(02), 63-72. Retrieved from http://ssrn.com/abstract $=2638744$

Raewf, M. B., \& Thabit, T. H. (2018). Influencing factors on customer satisfaction: Study on a sample of Arab restaurants in Malaysia. LAP-Lambert Academic Publisher, Germany.

Schilpzand, M. C., Martins, L. L., Kirkman, B. L., Lowe, K. B., \& Chen, Z. X. (2013). The relationship between organizational justice and organizational citizenship behaviour: The role of cultural value orientations. Management and Organization Review, 9(2), 345-374. https://doi.org/10.1111/more.12014

Shan, S., Ishaq, H. M., \& Shaheen, M. A.
(2006). Impact of organizational justice on job performance in libraries Mediating role of leader-member exchange relationship. Library Management, 36((1\2)), 70-85.

SJR. (2020). Scimago Journal and Country Rank. Retrieved from Scimago Journal and Country Rank website: https://www.scimagojr.com/countryrank.php?region=Middle East

Suliman, A., \& Kathairi, M. Al. (2013). Organizational justice, commitment and performance in developing countries: The case of the UAE. Employee Relations, 35(1), $\quad 98-115 . \quad$ https://doi.org/10.1108/01425451311279438

Thabit, Thabit H., \& Raewf, M. B. (2018). The Evaluation of Marketing Mix Elements: A Case Study. International Journal of Social Sciences \& Educational Studies, 4(4), 100-109. https://doi.org/10.23918/ijsses.v4i4p100

Thabit, Thabit H, \& Jasim, Y. A. (2016). The Role of Environmental Accounting Disclosure to Reduce Harmful Emissions of Oil Refining Companies. The 3rd International Conference on Energy, Environment, and Applied Science, Ishik University, Erbil, Iraq.

Thabit, Thabit H, \& Jasim, Y. A. (2019). The challenges of adopting E-governance in Iraq. Current Res. J. Soc. Sci. \& Human., 2, 31.

Thabit, Thabit H, Raewf, M. B., Abdulrahman, O. T., \& Younis, S. K. (2016). The Adoption of E-commerce in SMEs A case study on a sample of Iraqi enterprises. International Journal of Latest Research in Engineering and Technology, 2(6), 38-46.

Thabit, Thabit Hassan, \& Raewf, M. B. 
(2016). The Impact of Voluntary Disclosure on Investor Reactions. Journal of Global Business and Social Entrepreneurship (GBSE), 4(5), 19-31.

Tinuke, F. M. (2015). Dimensions of University Academic Staff Performance Appraisal in Selected Public Universities in Nigeria. Journal of Global Economics Management and Business Research, 3(3), 139-147.

Tyler, T. R. (1989). The Psychology of Procedural Justice: A Test of the Group-Value Model. Journal of Personality and Social Psychology. https://doi.org/10.1037/0022-3514.57.5.830

Webometric. (2020). Webometric ranking of world universities. In Webometric Website. Retrieved from http://www.webometrics.info/en/Asia_Pacifico/Middle_East

Wei, F., \& Lee, J. (2015). The moderating effect of leadership on perceived organizational justice and affective commitment: a study in China. International Journal of Human Resource Management, 28(5), 679-702. https://doi.org/10.1080/09585192.2015.1109533

Yousefi, M., \& Abdullah, A. G. K. (2019). The impact of organizational stressors on job performance among academic staff. International Journal of Instruction, 12(3), 561-576. https://doi.org/10.29333/iji.2019.12334a

Yu, J., Lee, A., Han, H., \& Kim, H.-R. (2019). Organizational Justice and Performance of Hotel enterprises: Impact of Job Embeddedness. Journal of Quality Assurance in Hospitality \& Tourism, DOI: 1-24. Zapata-Phelan, C. P., Colquitt, J. A., Scott, B. A., \& Livingston, B. (2009). Procedural justice, interactional justice, and task performance: The mediating role of intrinsic motivation. Organizational Behavior and Human Decision Processes, 108(1), 93-105. https://doi.org/10.1016/j.obhdp.2008.08.001 


\title{
DETERMINANTS OF LEVERAGE: EVIDENCE BASED ON BSE LISTED INDIAN AUTO ANCILLARY FIRMS
}

\author{
Animesh Bhattacharjee \\ Department of Commerce, Tripura University, \\ Suryamaninagar, Agartala, Tripura (West), India. \\ E-mailid:bhatt.ani725@gmail.com \\ Madhu Kumori \\ Department of Commerce, Tripura University, \\ Suryamaninagar, Agartala, Tripura (West), India. \\ E-mail:19madhulika@gmail.com \\ Joy Das \\ Department of Commerce, Tripura University, \\ Suryamaninagar, Agartala, Tripura (West), India. \\ E-mailid:joydas@tripurauniv.in
}

\begin{abstract}
The primary objective of the present article is to investigate the impact of growth, liquidity, non-debt tax shield, profitability, size and tangibility on financial leverage with reference to Bombay Stock Exchange listed Indian auto ancillary firms. The study covered a period of 8 years (2013-2020) and applied correlation analysis, granger causality test and panel regression analysis. The findings of correlation analysis show that liquidity, profitability, and tangibility have significant association with financial leverage. The result of granger causality test indicates that liquidity and profitability granger cause leverage. Lastly, the regression analysis shows that liquidity and profitability have a significant negative impact on firms' leverage. Overall, findings of the study support the pecking order theory.
\end{abstract}

Keywords: Financial leverage, liquidity, profitability, panel regression.

\section{Introduction}

The decision of capital structure is related to the distribution of sources of finance in such a way that maximizes the value of a firm. The seminal paper Modigliani and Miller (1958) assumed a complete and perfect capital market and suggested that the capital structure theories are irrelevant in determining the value of a firm. The irrelevance theory of capital structure raised a debate on capital structure theories. The assumption of a perfect capital market is, basically, an ideal scenario where all securities are fairly priced without any market friction. It was a normative theory that was the basis of many other theories that tried to incorporate some of the actual market frictions and explain how these help in determining the capital structure of a firm and led the debate towards a positive theory. A comprehensive theory which covers all aspects of financing behaviour does not exist. The trade-off theory, market timing theory, signalling theory, agency cost theory, free cash flow theory, pecking order theory are the theories that try to explain the variation in leverage of different firms. These theories are results of the deviations from the perfect market assumption and tried to explain the behaviour of firms while making capital structure 
decisions in the presence of the imperfections or frictions of the market. According to the general trade-off theory, a firm which needs funds to finance an investment opportunity will trade-off between the costs and benefit of having leverage in the capital structure and accordingly decide the optimum level of leverage (Ikpesu and Eboiyehi, 2018; Fama and French, 2002). The agency cost of theory assumes that the separation of ownership and control exerts agency costs on the firm (Kochhar, 1996). Managers act as agents of equity and debt-holders and sometimes take a decision that favours only a particular group, not the value of the firm. The free cash flow anomaly explains how the availability of extra funds makes managers takes suboptimal decisions that favour them and create a cost to the firm. The idea of market timing theory explains that a firm can take advantage of the market performance and issue the shares accordingly. The signalling theory explains that due to information asymmetry the outside investors may not be able to gauge the actual worth of the firm or the investment opportunity for which the firm needs financing; they take signals of firm value from the decisions taken by the firms (Levy and Lazarovich-Porat, 1995). In contrast to the trade-off theory, the pecking order theory suggests that there is no optimal target of leverage (Myers, 1984). Due to information asymmetry, different financing sources bear different costs and to maximize the firm value, financing sources with less information asymmetry should be issued first. The theory suggests that firms should first employ internal funding, then debt and then equity.

These theories, in their general forms, were not able to explain much variation in leverage across firms. The literature on capital structure used them combined to explain the variation in the capital structure of firms. The present article will focus on the two main theories, the trade-off theory and the pecking order theory, and with the help of other theories explain the variation in leverage across firms. The terms leverage and financial leverage have been used interchangeably and the proxy for leverage is as per the suggestion by Chaklader and Chawla (2016).

The study will focus on the auto ancillary firms listed on the Bombay Stock Exchange. The Indian auto ancillary sector is world's fourth largest and is closely linked to the India automobile industry. Further, the Indian auto ancillary firms produce items whose requirements are recurring in nature. Thus, its contribution to GDP and employment is quite significant.

\section{Theoretical framework}

Trade-off theory

The trade-off theory originates from Modigliani and Miller (1958) which assumes a perfect and complete capital market with no frictions and thus, the capital structure decisions are value irrelevant. All the financing sources are perfect substitutes and the value of the levered firm will be equal to the value of the unlevered firm. Further, Modigliani and Miller (1963) relaxed the assumption of a complete and perfect capital market with the introduction of corporate taxes in the original model. The study considers the tax benefits of debt and described the value of levered firms as the present value of tax shield in addition to the value of the unlevered firm. Both the papers didn't consider the presence of bankruptcy penalties in their theories. Kraus and Litzenberger (1973) stated that the corporate taxes and bankruptcy penalties are central to the positive theories which explain the effect of leverage on value of the firm. In reality, the benefits arising with a tax shield is offset by the costs of financial distress and the theory which suggests a trade-off between the benefits and costs of issuing debt for getting an optimal level of 
leverage, named as trade-off theory. The tax benefits are observable but the costs are not, so it is safer for firms to maintain a safety of margin before taking tax benefits. Thus, the trade-off theory suggests that a firm should issue debt only up to the level where the benefits are more than or equal to the costs.

It may be worth noting that getting the tax benefits are not the only incentive for debt issues. It also relates to mitigating the agency costs and free cash flow problems. Debt issue generates various types of problems and incentives while managing the business which leads to conflict of interest between managers, shareholders, and debt-holders. These costs are named as asset substitution problems and underinvestment. Debts are less risk bearing assets and they are issued basically for less risky investments than equity. Sometimes managers act in the favour of shareholders by issuing debts and use the proceedings to invest in more risky projects than the debt was contracted for. Since, debt-holders anticipate these behaviours they demand higher premiums on their debts increasing the cost of capital. This is known as asset substitution problem as it exchanges the lower risky investments for higher-risky investment. Firms may use asset substitution to please shareholders. It may increase the value of shareholders but damages the debt-holders and thus, value of the firm may be unaffected by the move. The problem of underinvestment through agency problems arises when firms take decisions to not undertake a profitable project (a positive NPV project) because the profits will be partly shared by the debt-holders while the risk is borne by the equity-holders. It is a cost to the value of a firm. Managers take the decision to under-invest especially when risky debts are present in the market. The success of a profitable project may lead to higher valuation of debts at the cost of shareholders. These costs prevent firms from issuing more debts.

The main concern of the trade-off theory is to search for the ways which help in reducing the costs of debt issue and increasing the benefits of it. The static version of trade off theory assumes an optimum level of debt which a firm chose according to its costs and benefits. The dynamic trade off theory assumes that although the firms choose their target levels but they deviate from their target and again try to adjust the debt level to reach their targets.

Pecking order theory

The assumption of perfect capital markets leads the financing decisions value irrelevant and makes the internal and external financing substitutes of each other (Modigliani \& miller, 1958). However, market imperfections lead to considerable wedge between the decision to finance from internal sources and external sources and make the decision related to capital structure relevant for valuation of firms (Vanacker and Manigart, 2010). Myers and Majluf (1984) tried to count on these inefficiencies of the market and added the condition of information asymmetry with the assumption of a perfect capital market. The study explains how the capital structure of a firm, which has asset-in-place and needs additional financing for investment opportunities, is influenced when managers of the firms are more informed than outside investors and the managers as well as the outside investors are aware of the fact. Transmitting complete information to outside investors is very costly.

Since, managers cannot provide the information to outside investors, information is signalled to outside investors through decisions taken by them. The information asymmetry is perhaps the most important source to know why the external financing is thought to be more costly than the internal one. With this, the theory of pecking order came into being which posits that there should be 
an order of preferring the sources of finance in which the least costly should be preferred first. In other words, the internal financing should be preferred and in case it exhausts, external financing may be the next option. Availability of internal financing can safely avoid the need of external financing and be helpful to avoid consequences of manager's inside information.

External financing (issuing debt or equity), on the other hand, may lead to asset mispricing at the marketplace which will cause a loss of value. The firms which have investment opportunities may not issue equity as they are aware that outside investors may not gauge the actual worth of the firm's assets as well as the future prospects of growth and the shares issued may remain under-priced. The growth opportunity increases the information asymmetry. Hence, if a firm issues new capital, it may signal outside investors the bad news (market signalling). The outside investors may perceive that the asset in place is overvalued and hence, the managers are issuing new stocks, because if it had been undervalued, they may not have issued new shares. Thus, it affects the stock prices of the firm. The firm may fail to accept the opportunity to invest in a profitable project (Underinvestment problem) (Rocca et al., 2007). Here, Myers and Majluf (1984) argued that in absence of internal financing, Debt should be issued as it bears less information asymmetry and share prices will not be mispriced. In comparison to equity, debt bears less cost and leads to less information asymmetry because debt-contracts are safer as they limit the possible amount which the debt-holders may lose. Among the debts, risk-free debts and secured debts have least cost than the unsecured one. The main concern of the pecking order theory is how to reduce information asymmetry.

\section{Literature review}

This section discusses various significant contributions made by researchers on the literature of determinants of a firm's capital structure.

Booth et al. (2001) examined the difference in capital structure of developed and developing countries over the period of 10 years and fund that the firm specific determinants of capital structure affect the developing countries in the same way they affect the developed countries. However, the country specific factors affect the ratios in different way which creates the variation in ratios among the countries.

Mishra (2011) investigated the determinants of capital structure of 48 profit making PSUs of manufacturing sector. The study found the profitability of firms was negatively while the growth opportunity and tangibility were positively related with leverage. Tax rate had a negative coefficient which was against the expectations of trade off theory. The relationship of profitability and growth was according to the pecking order theory while that of the tangibility was according to the trade-off theory. The effect of non-debt tax shield and size of the firms were insignificant factor for the period observed.

Ali (2011) enquired about the determinants of capital structure for textile companies listed on Bombay Stock Exchange. The study period extends from the year 2006 to 2010 and considered 170 textile companies. Only long-term debt had been used for defining leverage ratio and the study found that profitability and growth in total assets were negatively related with leverage while size of the firms, non-debt tax shield and asset tangibility shared a positive relationship with leverage.

Serrasqueiro and Caetano (2012) investigated into the practices of determining 
capital structure of SMEs of Portugal over the period 1998 to 2005 . The study found the profitability and age of the firms were negatively related to debt ratio. The results are consistent with pecking order theory. Again, the firms were found to be making a considerable adjustment towards their target capital which proves that the firms also consider the trade-off theories. The growth opportunities and tangibility had insignificant relationship with debt ratio for the period observed.

Gonzalez and Gonzalez (2012) examined the determinants of capital structure and the behaviour of these factors depending upon the size of the firms in Spain. The results supported both the theories as non-debt tax shield were negatively related to debt ratio and debt level of previous years were positively related according to the explanation of the trade-off theory. And Growth opportunity, intangibility and size had positive association while profitability had negative association with debt ratio according to the theory of pecking order. However, the study further emphasizes that the degree of usage of the theories varies across firm size but the direct of the relationship remains the same.

Abdeljawad et al. (2013) advocated the presence of trade off theory in financing behaviour of Malaysian firms. The study found the evidence of target reversion behaviour which actually satisfies the criteria of adopting trade-off theory. But again, for target reversion, the firms may balance the costs and benefits of financing the firm by taking the advantage of market situation. Hence, firms may deviate from trade off to pecking order or say to market timing for financing. Overall, the study concludes that with differences in size, patterns, leverage level in the firms, they may adopt any theory or a combination of that for financing themselves.
Handoo and Sharma (2014) examined the factors affecting the capital structure of 870 listed Indian firms from 2001 to 2010. Both private as well as government firms were considered for analysis. The study prepared 3 models with different dependent variables. First model which considered short term debt as leverage found profitability, asset tangibility, size of the firm, tax rate and debt servicing capacity being the major determinants. Another model with long term debt as leverage found the profitability, growth, tangibility, cost of debt, tax rate, and debt servicing capacity as major determinants. Third model which considered total debt as leverage found all the factors in the above models as important determinants except the cost of debt.

Komera and P.J. (2014) investigated the validity of pecking order theory in presence of debt concerns. The study covers the data of all public listed companies in India from the year 1992 to 2011. The pecking order is expected to be performing well for small firms as these firms exhibit information asymmetry but did not seem to be true in case of small firms. Overall, the study found that tangibility and size shared a positive while growth and profitability shared a negative relationship with leverage. For emphasizing the effect of financial deficit, it was included in the regression but the $\mathrm{R}$-square was remained moreover same as before and the signs of all the factors also remained unchanged. With this the study concluded that pecking order doesn't seem to work well even in case where the debt capacity of the firms became a concern. Overall, the study negates the validity of pecking order theory.

Chadha and Sharma (2015) tried to find the important determinants of capital structure in manufacturing firms with special reference to India. The study 
extends over a period of 10 years, from 2003-04 to 2012-13 and considered 422 listed firms for analysis. The size and age of the firms, asset tangibility, growth, profitability, non-debt tax shield and business risk were found to be the important determinants of capital structure of the firms for the observed period. In addition, the study also comments that a mix of both the trade-off and pecking order theories explains the determinants of capital structure of these firms.

Harc (2015) examined 500 small and medium enterprises in Croatia with data from the year 2005 to 2010. The study concluded that tangible assets behaved differently with short term debt and long-term debt. It shared a positive association with long term debt and a negative association with short term debts. Since between the tangibility and leverage, the trade-off theory and pecking order theories advocates a positive and negative signs respectively, the study specified that the firms consider trade off theory while thinking about the long-term financing and consider pecking order theory while taking decisions for short term financing.

Adair and Adaskou (2015) investigated 2370 small and medium enterprises (SMEs) to analyse the determinants of their capital structure in order to know whether the firms apply the trade-off theory or the pecking order theory while determining the capital structure. The study found that with the increasing age of the firms and increased profitability, the debt ratio was reduced while the growth of the firms had a positive association with debt ratio. It signifies the use of pecking order theory. Also, the study reports that trade credit and guarantee or firms had a positive relationship with debt ratio which confirms with the trade-off theory. The effect of risk which varies among different types of industries and size were found to be insignificant on debt ratio.

Rao et al. (2017) investigated the factors that determine the capital structure of Indian manufacturing firms. The study applied panel data analysis and found that the depreciation, research \& development expenditure, and liquidity were positively related to the leverage while profitability and tangibility were negatively related.

Sofat and Singh (2017) analysed the top 100 manufacturing companies listed in BSE for finding the most significant determinants of capital structure in India. The study found the profitability with a negative relationship to leverage while asset composition and business risk had a positive relationship with leverage. Firm size was found to be an insignificant determinant. Thus, the study found a mix of capital structure theories explaining the behaviour of the determinants and the profitability, asset composition and business risk were considered as significant determinants of capital structure for the observed period.

Nasution et al. (2017) examined the determinants of capital structure of manufacturing companies in Indonesia. The study found that the profitability and non-debt tax shield were negatively related to leverage while the tangibility had a positive relationship with leverage. Corporate tax and inflation had insignificant relationship.

Sakr and Bedeir (2019) investigated whether the capital structure decisions of publicly traded non-financial firms are explained by the trade-off theory, pecking order theory or the agency cost theory. The study concluded that profitability, size, tangibility, liquidity, growth, business risk and financial flexibility were the important determinants of 
capital structure for the selected firms and the trade-off theory as well as pecking order theory combined explains the relationship between the determinants and the leverage.

Simatupang et al. (2019) enquired about the capital structure determinants of publicly listed non-financial companies in Indonesia and found that the profitability and tangibility were determining the capital structure of the selected firms while sales growth and non-debt tax shield were not found to be the significant determinants.

Sikveland and Zhang (2020) examined the sources of leverage for aquaculture industry in Norway and considered long term debt, short term debt, total debt, and liquidity of firms as a proxy of leverage. The study found that the listed firms have a significant negative relationship with all proxies of leverage as getting equity is easier for them and thus, listing of firms is also an important variable for explaining the sources of capital structure. Further, the study reports that the proxies of size and profitability of the selected firms share a negative relationship with short term as well as total debt and tangibility is positively related with long term debt and total debt while it shares a negative relationship with short term debt.

Gharaibeh and Tahat (2020) enquired about the factors that explain the level of leverage for service companies in Jordan. The study considered 45 companies for analysis and with panel regression it concluded that the size and non-debt tax shield had a positive relationship with debt ratio while profitability and business risk had a negative relationship.

\section{Determinants and their relationship with leverage}

Profitability- According to the trade-off theory, more profitable firms possess more debt servicing capacity and hence, should issue more debts to take the benefit of tax shield. Thus, the theory predicts a positive relationship between a firm's profitability level and leverage. The pecking order theory suggests that with more profitability, a firm will be able to accumulate more surpluses which help the firm avoid external financing. The more profitable a firm, the less it needs to go for debt. Thus, pecking order assumes a negative relationship between profitability and leverage. Studies Fama and French (2002), Onofrei et al.(2015), Akingunola and Oyetayo (2014) considered profitability as a deteminant of leverage.

Growth Opportunities- The trade-off theory assumes that growth opportunities come with agency problems between owners and creditors. The owners have great incentives to under-invest and also by asset substitution. Thus, with growth opportunities firms may prefer less to avoid the costs related to agency problems (Fama and French, 2002). The theory assumes a negative relationship between growth opportunities and leverage. As per the pecking order theory, growth opportunities need more financing and the firms with less retained earnings may need to increase the leverage. Firms with more earnings available may create the problem of excess cash flow. With this excess cash, managers may take advantage of information asymmetry and invest in negative- NPV projects that lead to more internal benefits to managers while firms will lose the value. The problem of excess cash may be mitigated by issuing more debt which needs regular and fixed payments and hence prevent the misuse of excess cash by investing in sub-optimal projects. Thus, the pecking order theory predicts that the firms with more growth opportunities will have a positive relation- 
ship with leverage. Studies of Fama and French (2002), Onofrei et al.(2015), Akingunola and Oyetayo (2014) and Rao et al. (2017) considered growth opportunity as a deteminant of leverage.

Tangibility - The trade-off allows benefits of debt to increase and costs of debt to reduce. With tangible assets more debt can be raised with less cost as tangible assets work as collateral and help to reduce financial distress. Hence, tangibility has a positive relationship with leverage in the framework of trade-off theories. As per the pecking order, more tangible assets will help in lesser information asymmetry and help in better pricing of new issues. Hence, firms may not have problems while issuing new equity. Also, the firms may retain the capacity to issue debt in near future. Thus, pecking order predicts a negative relationship of leverage with tangibility. Studies of Onofrei et al. (2015), Akingunola and Oyetayo (2014) considered tangibility as a determinant of leverage.

Liquidity- More liquidity allows more debt servicing capacity which leads to more benefit of tax shield. Thus, trade-off theory predicts a positive relationship between liquidity and leverage. But the pecking order assumes a negative relationship with leverage and suggests that with more liquidity, firms should prefer internal financing rather than relying on debt. Studies of Onofrei et al. (2015), Rao et al.(2017) considered liquidity as a determinant of leverage.

NDTS- The non-debt tax shields are substitutes of interest cost of debt as they also provide tax benefits. With increasingly non-debt tax shields, the incentive of receiving tax benefits from interest will be lesser and hence it leads to lower levels of leverage. Again, the more non-debt tax shields are allowed for deduction, the less profitability remains. It further leads to less debt servicing capacity of the firm. Thus, an increase in NDTS reduces the benefit of having more leverage. The trade-off theory predicts a negative relationship between NDTS and leverage. In contrast, the pecking order assumes a positive relationship. Since NDTS reduces the available earnings, it may dent a significant portion of internal financing and hence, more debt will be issued with increasing levels of NDTS.Rao et al. (2017) considered NDTS as a determinant of leverage.

Size - Larger firms used to be more diversified and less prone to bankruptcy. Debt-holders can be easily attracted towards large sized firms with favourable costs to firms in comparison to the smaller ones. Hence, larger firms have more incentive in debt servicing than the smaller firms. The trade-off theory predicts a positive relationship between size of the firms and leverage. Since the pecking order theory finds benefit where information asymmetry can be reduced, it favours a negative relationship between the two. It states that with large size, firms attract more regulation and control which in turn reduces information asymmetry to a great extent. Hence, the size of the firm and leverage should reflect a negative relationship. Studies of Fama and French (2002), Onofrei et al.(2015), Akingunola and Oyetayo (2014) considered size of the firm as a determinant of leverage.

\section{Objective of the study}

1. To investigate the impact of growth, liquidity, non-debt tax shield, profitability, size and tangibility on financial leverage of BSE listed auto ancillary firms.

2. To examine whether the findings are 
consistent with the pecking-order theory or trade-off theory.

Author mentioned in the abstract that the primary objective of the paper is, but between these two objectives we don't know which one is primary objective.
April to 31st March) 2013 to 2020. The study considered such a time frame in order to capture the period after the recovery of the Indian economy from the sub-prime crisis. All the data is sourced from the money control web site and are in INR. The variables and the proxies used in the study are summarised in Table 1.

\section{TABLE 1 OPERATIONAL DEFINITION OF THE VARIABLES}

\begin{tabular}{|c|c|c|c|}
\hline & Variables & Proxy Used & Symbol \\
\hline $\begin{array}{l}\text { Dependent } \\
\text { Variable }\end{array}$ & Leverage & $\frac{\text { CL }+ \text { LTD }}{\text { TA }}$ & $L E V$ \\
\hline \multirow[t]{6}{*}{$\begin{array}{l}\text { Independent } \\
\text { Variables }\end{array}$} & Growth & $\frac{\text { (Current year sales }- \text { Previous year sales) }}{\text { Previous year sales }} \times 10$ & GROW \\
\hline & Liquidity & $\nabla \nabla$ & $L Q D$ \\
\hline & $\begin{array}{l}\text { Non Debt } \\
\text { Tax Shield }\end{array}$ & $\frac{\text { Dep + Amortisation }}{\mathrm{TA}}$ & NDTS \\
\hline & Profitability & $\frac{\mathrm{NPAT}}{\mathrm{TE}}$ & PROFIT \\
\hline & Size & Log transformation of total assets & SIZE \\
\hline & Tangibility & $\frac{\mathrm{FA}}{\mathrm{TA}}$ & $T A N G$ \\
\hline
\end{tabular}

\section{Methodology}

The primary objective of the study is to investigate the impact of growth, liquidity, non-debt tax shield, profitability, size, and tangibility on financial leverage. For the purpose of the present study; we have considered BSE Group A listed firms belonging to the auto ancillaries sector. The auto ancillaries sector has 13 firms and we have included 10 of them in the study whilethree firms are left out due to the unavailability of data. The period of the study was for the financial year (1st
Note: CL is current liabilities, LTD is long-term debts, TA is total assets, CA is current assets, Dep is depreciation, NPAT is net profit after tax, TE is total equity and FA is fixed assets.

The study employed panel data regression to achieve the pre-specified objective of the study. To choose between the fixed effects model (FE) and the random effects model (RE), the Hausman test is applied. The null hypothesis of the test is that Random Effects model is consistent while the 
alternative hypothesis is that the Fixed Effects model is consistent. Thus, if the $\mathrm{p}$-value is less than 0.05 we can reject the null hypothesis.

To investigate the impact of the selected variables the following model is framed for the regression analysis:

\section{[LEV $]_{-}(\mathrm{i}, \mathrm{t})=B_{-} 0+B_{-} 1 \quad$ (GROW $\left.)\right]$} $(\mathrm{i}, \mathrm{t})+$ B_2 $\left[(\mathrm{LQD}) \bar{\nabla} \_(\mathrm{i}, \mathrm{t})+\right.$ B_3『(NDTS $)$ $\bar{\Sigma}(\mathrm{i}, \mathrm{t})+B_{-} 4$ 『(PROFIT $\left.)\right]_{-}(\mathrm{i}, \mathrm{t})+B_{-} 5$ $(\mathrm{SIZE}) \rrbracket_{-}(\overline{\mathrm{i}}, \mathrm{t})+B_{-} 6$ 【(TANG) $\rrbracket_{-}(\mathrm{i}, \overline{\mathrm{t}})+\varepsilon$ -(i,t)

Where, LEVi, $t$ is leverage of the ith firm at time $t, B 0$ is the constant, $B 1$ to $B 6$ are the coefficients of the independent variables, GROWi, $t$ is the growth of theith firm at time $t, \mathrm{LQDi}$, tis the liquidity of theith firm at time $t$, NDTS $i$, $t$ is the non-debt shield of the ith firm at time t, PROFIT i, $t$ is the profitability of the ith firm at time $t, S I Z E i, t$ is the size of the ith firm at time $t, T A N G i$, $t$ is the tangibility of the ith firm at time $t, c i, t$ is the error term.

In the first step the summary statistics of all the variables viz. mean, standard deviation, skewness and kurtosis are computed. Correlation coefficients are computed to observe the association between the variables.
The granger causality test is applied to investigate the direction of causality in the short-run. The Hausman test is applied to determine whether the fixed effect or the random effect is appropriate and finally, the regression result is reported.

\section{Discussion}

The summary statistics of the variables are summarised in Table 2. The mean value of leverage, growth, liquidity, non-debt tax shield, profitability, size and tangibility is $0.3534,8.7580,1.7328$,

$0.0427,12.7428,43.5834$ and 0.3369 respectively. The distribution of leverage, liquidity, NDTS, profitability, size and tangibility is skewed to the right (positively skewed) while the distribution of growth is skewed to the left (negatively skewed). The kurtosis value of all the variables is more than 3 which indicates that all the variables follow a leptokurtic distribution. The Jarque-Bera test indicates that at 5 per cent level only tangibility follows normal distribution.

\section{TABLE 2 DESCRIPTIVE STATISTICS}

\begin{tabular}{|l|l|l|l|l|l|l|l|}
\hline & LEV & GROW & LQD & NDTS & PROFIT & SIZE & TANG \\
\hline Mean & 0.3534 & 8.7580 & 1.7328 & 0.0427 & 12.7428 & 43.5834 & 0.3369 \\
\hline Std. Dev. & 0.1494 & 15.6472 & 0.8684 & 0.0181 & 13.2729 & 205.7469 & 0.1324 \\
\hline Skewness & 1.9050 & -0.4357 & 1.9596 & 0.6798 & 1.5543 & 4.9307 & 0.3946 \\
\hline Kurtosis & 10.0595 & 5.1900 & 8.9250 & 3.0251 & 4.8559 & 25.5335 & 2.9740 \\
\hline $\begin{array}{l}\text { Jarque- } \\
\text { Bera }\end{array}$ & 214.513 & 18.519 & 168.223 & 6.165 & 43.695 & 2016.692 & 2.078 \\
\hline \begin{tabular}{l} 
Prob. \\
\hline
\end{tabular} & 0.0000 & 0.0000 & 0.0000 & 0.0458 & 0.0000 & 0.0000 & 0.3537 \\
\hline
\end{tabular}


From the correlation analysis (Table 3) all the correlation coefficients are less than 0.8. Further, there is no correlation between the independent variables which indicates that the problem of multicollinearity does not exist and all the independent variables can be used for the purpose of regression analysis simultaneously. (needs further clarification)
Source: Author's Own calculation t-stat in [] and p-value in ()

TABLE 3 CORRELATION ANALYSIS

\begin{tabular}{|l|l|l|l|l|l|l|l|}
\hline & LEV & GROW & LQD & NDTS & PROFIT & SIZE & TANG \\
\hline LEV & 1.000 & & & & & & \\
\hline GROW & 0.1551 & 1.000 & & & & & \\
& {$[1.387]$} & & & & & & \\
& $(0.1693)$ & & & & & & \\
\hline LQD & -0.5918 & -0.1340 & 1.000 & & & & \\
& {$[-6.485]$} & {$[-1.194]$} & & & & & \\
& $(0.0000)$ & $(0.2359)$ & & & & & \\
\hline NDTS & 0.0977 & -0.0035 & -0.2831 & 1.000 & & & \\
& {$[0.867]$} & {$[-0.031]$} & {$[-2.607]$} & & & & \\
& $(0.3883)$ & $(0.9753)$ & $(0.0109)$ & & & & \\
\hline PROFIT & -0.4558 & -0.0621 & 0.4940 & -0.1016 & 1.000 & & \\
& {$[-4.522]$} & {$[-0.549]$} & {$[5.018]$} & {$[-0.902]$} & & & \\
& $(0.0000)$ & $(0.5841)$ & $(0.0000)$ & $(0.3694)$ & & & \\
\hline SIZE & -0.0389 & -0.0867 & -0.1108 & -0.2545 & -0.0664 & 1.000 & \\
& {$[-0.343]$} & {$[-0.769]$} & {$[-0.985]$} & {$[-2.324]$} & {$[-0.588]$} & & \\
& $(0.7319)$ & $(0.4441)$ & $(0.3275)$ & $(0.0227)$ & $(0.5582)$ & & \\
& & & & & & & \\
\hline TANG & 0.2479 & -0.0441 & -0.3915 & 0.6464 & -0.3515 & -0.1625 & 1.000 \\
& {$[2.260]$} & {$[-0.390]$} & {$[-3.757]$} & {$[7.483]$} & {$[-3.316]$} & {$[-1.455]$} & \\
& $(0.0266)$ & $(0.6975)$ & $(0.0003)$ & $(0.0000)$ & $(0.0014)$ & $(0.1496)$ & \\
\hline
\end{tabular}


The output of granger causality test is presented in Table 4. From the table it can be observed that uni-directional causality exists between liquidity and leverage and profitability and leverage which indicates that liquidity and profitability improves the prediction of leverage in the regression model.

\section{TABLE 4 PAIRWISE GRANGER CAUSALITY TEST}

\begin{tabular}{|l|l|l|}
\hline Null Hypothesis: & F-Statistic & Prob. \\
\hline GROW does not Granger Cause LEV & 0.04298 & 0.8364 \\
\hline LEV does not Granger Cause GROW & 0.02779 & 0.8681 \\
\hline LQD does not Granger Cause LEV & 8.87167 & 0.0040 \\
\hline LEVdoes not Granger Cause LQD & 0.20943 & 0.6487 \\
\hline NDTS does not Granger Cause LEV & 0.08633 & 0.7698 \\
\hline LEV does not Granger Cause NDTS & 0.65998 & 0.4194 \\
\hline PROFIT does not Granger Cause LEV & & 0.0340 \\
\hline LEV does not Granger Cause PROFIT & 4.68489 & 0.4638 \\
\hline SIZE does not Granger Cause LEV & 0.54286 & 0.8693 \\
\hline LEV does not Granger Cause SIZE & 0.02727 & 0.8732 \\
\hline TANG does not Granger Cause LEV & & 0.02566 \\
\hline LEV does not Granger Cause TANG & & \\
\hline
\end{tabular}

The output of the regression analysis is presented in table 5. From the table it can be observed that the idiosyncratic error (Rho) is more than 64 per cent which suggests that it is better to apply panel data regression then pooled regression. 
The study applied both the method of panel data regression i.e. fixed effect and random effect. The best model is selected on the basis of the result of Hausman test.

\section{TABLE 5 PANEL REGRESSION TEST RESULTS}

\begin{tabular}{|c|c|c|c|c|c|c|c|c|}
\hline & \multicolumn{4}{|c|}{ FE } & \multicolumn{4}{|c|}{$\mathrm{RE}$} \\
\hline Variables & Coefficient & S.E. & t-stat & Prob & Coefficient & S.E. & t-stat & Prob \\
\hline $\mathrm{C}$ & 0.5670 & 0.1062 & 5.336 & 0.000 & 0.5673 & 0.0917 & 6.185 & 0.000 \\
\hline GROW & 0.0005 & 0.0009 & 0.600 & 0.550 & 0.0005 & 0.0009 & 0.653 & 0.515 \\
\hline LQD & -0.0796 & 0.0360 & -2.206 & 0.030 & -0.0823 & 0.0275 & -2.994 & 0.003 \\
\hline NDTS & -0.3818 & 1.6126 & -0.236 & 0.813 & -0.6209 & 1.3516 & -0.459 & 0.647 \\
\hline PROFIT & -0.0032 & 0.0024 & -1.357 & 0.179 & -0.0029 & 0.0017 & -1.681 & 0.096 \\
\hline SIZE & $\begin{array}{l}-0.0001 \\
\end{array}$ & $8.44 \mathrm{E}-05$ & -1.317 & 0.192 & -0.0001 & $7.75 \mathrm{E}-05$ & -1.354 & 0.179 \\
\hline TANG & -0.0521 & 0.2161 & -0.241 & 0.810 & -0.0222 & 0.1890 & -0.117 & 0.906 \\
\hline
\end{tabular}

The output of the Hausman test (see Table 6) supports the random effects model and, thus, the rest of the regression analysis will be based on the random effect model only.The regression equation of the determinants of capital structure for BSE listed auto ancillaries firms is given below:

$\mathrm{LEV} \rrbracket \_(\mathrm{i}, \mathrm{t})=0.5673+0.0005 \llbracket(\mathrm{GROW}) \rrbracket$ (i,t)- $0.0823 \llbracket(\mathrm{LQD}) \rrbracket[(\mathrm{i}, \mathrm{t})-0.6209 \llbracket$ (NDTS)】_(i,t)- 0.0029 【(PROFIT)】_(i,t)$0.0001 \llbracket(\mathrm{SIZE}) \rrbracket \_(\mathrm{i}, \mathrm{t})-\quad 0.0222 \llbracket(\mathrm{TANG})$ $\Sigma_{-}(\mathrm{i}, \mathrm{t})+\varepsilon_{-}(\mathrm{i}, \mathrm{t})$

TABLE 6 HAUSMAN TEST

\begin{tabular}{|l|l|l|l|}
\hline Test Summary & Chi-Sq. Statistic & Chi-Sq. d.f. & Prob. \\
\hline Cross-section random & 0.359120 & 6 & 0.999 \\
\hline
\end{tabular}

The regression result shows that liquidity and profitability are the independent 
variables which significantly affect the leverage of the firm. Both the coefficient of liquidity and profitability is negative and statistically significant at 5 per cent and 10 per cent level, respectively. The negative sign of the coefficient of liquidity supports the pecking order theory which postulates that firms which maintain comfortable liquidity position finance through internal funds and rely less on debt. Further, the negative sign of the coefficient of profitability also supports the pecking order theory. Thus, as per the theory a firm earning high profits finance through internal funding and would avoid outside financing. The negative relationship between liquidity and leverage and profitability and leverage is in line with the findings of Serrasqueiro and Caetano (2012), Adair and Adaskou (2015) and Nasutionet al. (2017). The coefficient sign of growth is positive but insignificant. The positive relationship between leverage and growth is in consistent with the pecking order theory and is in line with the findings of Mishra (2011) and Adair and Adaskou (2015). Thus, according to the theory a growing firm with insufficient internal funding will prefer to issue debt instead of equity shares to meet the financing requirements. As per the theory issue of equity shares by a growing firm will signal the investors that the equity shares are overvalued and may result in massive sell-off. The negative relationship between the firm's leverage and the non-debt tax shield derived in the study supports the trade-off theory and is in line with the results of Gonzalez and Gonzalez (2012) and Nasutionet al. (2017). The trade-off theory theorises a positive relationship between size and the firm's leverage. According to the theory as a firm grows, its profitability also increases which in turn reduces the firm's probability of bankruptcy. Thus, larger firms have easy access to debt as compared to smaller firms. On the other hand, the pecking order theory supports the negative relationship between size and leverage. The present study found a negative relationship between size and leverage which is consistent with the pecking order theory. The regression equation shows that the relationship between tangibility and leverage is negative and insignificant. The negative coefficient of tangibility supports the pecking order theory. According to the theory as firm's tangible assets to total assets ratio improves the information asymmetry reduces, thus, making equity issuance less costly. In other words, firm's with higher tangible assets to total assets ratio have lower leverage.

The value of Adj. R2 is 0.1578 which indicates that around 16 per cent of the variation in leverage can be explained by the independent variables. The F-statistic is significant which suggests that the model fits the data significantly. Further, the value of the Durbin-Watson statistic is close to 2 which suggest that the problem of autocorrelation do not exist in the residuals.

\section{Conclusion}

The present study investigated the determinants of leverage with reference to BSE listed auto ancillary companies. The study covered a period of 8 financial years and employed correlation analysis, granger causality test and panel regression to analyse the data.The correlation analysis shows that leverage is positively correlated with growth, NDTS and tangibility while leverage is negatively correlated with liquidity, profitability and size. The correlation analysis further indicates that the multicollinearity problem does not exist between the independent variables. The result of the granger causality test suggests that unidirectional causality exists between liquidity and firm's 
leverage and profitability and firm's leverage. The study applied Hausman test to determine whether the fixed effect model or the random effect model is appropriate. The result of the Hausman test suggests that the random effect model is appropriate for the present study. The regression equation explains 16 per cent of the variation in leverage. The regression further reveals that liquidity and profitability have significant negative relationship with leverage while the coefficient of NDTS, tangibility, size is also found to be negative but insignificant. The regression equation suggests that growth of the firm has positive impact on the firm's leverage. The regression coefficients of liquidity, profitability, growth, size and tangibility supports the pecking order theory while the regression coefficient of NDTS supports the trade-off theory.

The present study used a single leverage proxy; however, running separate regressions with multiple leverage proxies and comparing the results could have been a better approach and may come up with new in-sights.

\section{References}

Abdeljawad, I., Mat-Nor, F., Ibrahim, I., \& Abdul-Rahim, R. (2013). Dynamic Capital Structure Trade-Off Theory: Evidence from Malaysia. International Review of Business Research Papers, 9(6), 102-110.

Adair, P., \& Adaskou, M. (2015). Trade-Off Theory Vs. Pecking Order Theory And The Determinants of Corporate Leverage: Evidence from a Panel Data Analysis upon French SMEs (2002-2010). Cogent Economics and Finance, 3.

Akingunola, R., \& Oyetayo, O. (2014). Determinant of financial structure decision in small and medium enterprises : a pilot study of selected registered companies in Nigeria. IOSR Journal of Economics and Finance, 3(1), 01-08.

Ali, L. (2011). The determinants of leverage of the listed-textile companies in India. European Journal of Business and Management, 3(12), 54-59.

Booth, L., Aivazian, V., Demirguc-Kunt, A., \& Maksimovic, V. (2001). Capital Structure in Developing Countries. The Journal of Finance, LVI(1), 87-130.

Chadha, S., \& Sharma, A. K. (2015). Determinants of Capital Structure: An Empirical Evaluation from India. Journal of Advances in Management Research, 12(1), 3-14.

Chaklader, B., \& Chawla, D. (2016). A study of determinants of capital structure through panel data analysis of firms listed in NSE CNX 500. Vision, 20(4), 267-277.

Fama, E. F., \& French, K. R. (2002). Testing trade-off and pecking order predictions about dividends and debt. The Review of Financial Studies, 15(1), 1-33.

Gharaibeh, O. K., \& AL-Tahat, S. S. (2020). Determinants of capital structure: evidence from Jordanian service companies. Investment Management and Financial Innovations, 17(2), 364-376.

Gonzalez, V. M., \& Gonzalez, F. (2011). Firm Size and Capital Structure: Evidence Using Dynamic Panel Data, Jounral of Applied Economics, Volume 44, Issue 36.

Handoo, A., \& Sharma, K. (2014). A Study on Determinants of Capital Structure in India. IIMB Management Review, 26, 170-182. 
Harc, M. (2015). The relationship between tangible assets and capital structure of small and medium- sized companies in Croatia. Review of Contemparary Business, Enterprenuership and Economic Issues. 213-224.

Ikpesu, F., \& Eboiyehi, O. C. (2018). Capital structure and corporate financial distress of manufacturing firms in Nigeria. Journal of Accounting and Taxation, 10(7), 78-84.

Kochhar, R. (1996). Explaining firm capital structure: the role of agency theory vs. transaction cost economics. Strategic Management Journal, 17(9).

Komera, S., \& P.J., J. L. (2014). Capital structure choice, information asymmetry,and debt capacity: evidence from India. Journal of Economics and Finance, $38(2)$.

Kraus, A., \& Litzenberger, R. H. (1973). A state-preference model of optimal financial leverage. The Journal of Finance, 28(4), 911-922.

Levy, H., \& Lazarovich-Porat, E. (1995). Signaling theory and risk perception: an experimental study. Journal of Economics and Business, 47(1), 39-56.

Modigliani, F., \& Miller, M. H. (1958). The Cost of Capital, Corporation Finance and the Theory of Investment. The American Economic Review, 48(3), 261-297.

Modigliani, F., \& Miller, M. H. (1963). Corporate income taxes and the cost of capital: a correction. The American Economic Review, 53(3), 433-443.

Myers, S. C. (1984). The capital structure puzzle. The Journal of Finance, XXXIX(3), 575-592.
Myers, S. C., \& Majluf, N. S. (1984). Corporate financing and investment decisions when firms have information that investors do not have. Journal of Financial Economics, 13, 187-221.

Nasution, A. A., Siregar, I., \& Panggabean, R. (2017). The effect of profitability, asset tangibility, corporate tax, non-debt tax shield and inflation upon the financial capital structure of the manufacturing companies listed on the Indonesian stock exchange. Advances in Economics, Business and Management Research, 36.

Onofrei, M., Tudose, M. B., Durdureanu, C., \& Anton, S. G. (2015). Determinant factors of firm leverage: an empirical analysis at Iasi country level. Procedia Economics and Finance, 20, 460-466.

Rao, K. T., Joshi, B. P., \& Khurana, I. (2017). Capital structure determinants: empirical evidence from listed manufacturing firms in India. Pacific Business Review International, 10(4), 17-21.

Rocca, M. L., Rocca, T. L., \& Cariola, A. (2007). Overinvestment and underinvestment problems: determining factors, consequences and solutions. Corporate Ownership \& Control, 5(1), 79-95.

Sakr, A., \& Bedeir, A. (2019). Firm Level Determinants of Capital Structure: Evidence From Egypt. International Journal of Financial Research, 10(1), 68-85.

Serrasqueiro, Z., \& Caetano, A. (2015). Trade-off theory versus pecking order theory: capital structure decisions in a peripheral region of Portugal. Journal of Business Economics and Management, 16(2), 445-466.

Sikveland, M., \& Zhang, D. (2020). Deter- 
minants of capital structure in the Norwegian salmon aquaculture industry. Marine Policy. https://doi.org/10.1016/j.marpol.2020.104061

Simatupang, H. J., Purwanti, L., \& Mardiati, E. (2019). Determinants of Capital Structures Based on the Pecking Order Theory and Trade-off Theory. Jurnal Keuangan dan Perbankan, 23(1), 84-96.

Sofat, R., \& Singh, S. (2017). Determinants of capital structure: an empirical study of manufacturing firms in India. International Journal of Law and Management, 59(6), 1029-1045.

Vanacker, T. R., \& Manigart, S. (2010). Pecking order and debt capacity considerations for high-growth companies seeking financing. Small Business Economics, 35, 53-69. 


\title{
IMPACT OF INTERNAL AND EXTERNAL PROMOTIONAL VARIABLES ON CONSUMER BUYING BEHAVIOR IN AN EMERGING ECONOMY - AN EMPIRICAL STUDY
}

\author{
Jesus Cuauhtemoc Tellez Gaytan \\ Professor of Finance, Tecnologico de Monterrey, San Luis Potosi, Mexico \\ Email: cuauhtemoc.tellez@tec.mx
}

\author{
A. M. Sakkthivel \\ Professor of Marketing, School of Business Skyline University College, Sharjah, UAE \\ Email:drsakkthi@gmail.com; Email: sakthivel@skylineuniversity.ac.ae
}

\begin{abstract}
Shohab Sikandar Desai
Associate Professor of Management and Marketing MENA College of Management, Dubai, UAE Email: Shohab.sikandar@mcm.ac.ae
\end{abstract}

\section{Gouher Ahmed}

Professor of International Business Skyline University College, Sharjah, UAE Email: gouher@usa.net; gouher.ahmed@skylineuniversity.ac.ae

\begin{abstract}
The purpose of the study is to investigate the impact of promotional and the word-of-mouth variables on consumer buying behaviour in the fast-emerging economy of the Sultanate of Oman with a population of 4.6 million including about 2.0 million expatriates. From our study it emerges that, all the promotion-mix variables have a significant impact over the consumer buying and decision making behaviour, but surprisingly there are no takers for the word of mouth variables. The advertising, internet, direct marketing and others have more impact, and sales promotions and external variables have less impact. The study helps firms and public authorities to seek excellent strategies in deciding the best product promotions and also to achieve the Omani government goal of 81 per cent of non-oil GDP by 2020.
\end{abstract}

Keywords: Promotion mix variables, external variables (word of mouth), consumer buying behavior, mobile communication services, construct analysis

\section{Introduction}

In today's competitive world, consumers receive billions of pieces of information from umpteen sources related to buying different products and services. The 'tonnes' of information tends to create a lot of confusion in the minds of consumers, (Sakkthivel, 2010; Amponsah and Ahmed, 2017). Companies spend billions of dollars in businesses to design effective business promotional-mix strategies to reach measures, and influence target consumers to buy their products and services. Although there are many businesses efforts to reach the target consumers, there may also be some external forces influencing consumer buying and decision making towards given products and services. The said forces may be called the word-of-mouth factors such as the influences of friends and relatives, bosses, elders of the family and clan, role models, etc. To counter this, the companies tend to use different promotional measures, such as advertising, sales promotion, direct marketing, corporate communications, internet and 
such in order to reach and influence the target consumers.

It's imperative to study the influence of the aforesaid promotional measures strategies on consumer buying behaviour in order to identify the degree to which the aforesaid variables impact the consumer buying behaviour. Hence, this study sets itself to identify and select the major promotional and non-promotional variables that influence the consumers' business or demand behaviour in respect of mobile communication services in the emerging market economy of the Sultanate of Oman.

The promotion mix variables are: advertising, sales promotion, direct marketing, internet, etc., which are internal to the firm. The non-promotional external variables are: word-of-mouth, opinion/reference groups, boss, elders, role models etc. Customer care is used in the study as the direct marketing variable, as customer care is used to reach the consumers in the market selected for the study. Excluded are corporate communications (public relations) as the said variables are not effectively used by the companies in the market selected for the study. Thus, promotion mix variables are: advertising, sales promotion, direct marketing (customer care) and internet. A model is built on these variables for the purpose of this study, and for further research on the problem. This modest exercise is significant by itself and as a contribution to marketing theory from an Arab perspective. The study is organized around: Introduction, Literature Review, Objectives and Methodology, Data and Analysis, Implications, Limitations, and Further Research.

\section{Literature review}

Numerous studies have been held to understand the role of promotion in influencing consumer market buying behavior. However, these studies do not include all the variables that have been selected for this study in order for it to identify and build a model of variables that would demonstrate an impact on consumer buying behavior. Also, none of the studies has attempted to identify the degree of impact of the variables on the consumer buying behavior. Hence, the problem defined for the study is to identify and bridge the gaps from the earlier studies, in order to provide a comprehensive model of the variables that would have an impact on consumer buying behavior. The exercise is conducted in the Arab Sultanate of Oman, with a sample of 55 customers from the place of Sur.

A study by Nicolas et al. (2020) explores the development of consumer behavior research trends that show high-frequency keywords at different time periods using the bibliometric methods to analyze publications between 1990 and 2017. The study shows the evolution of keywords to reveal emerging topics which includes "advertising," "consumer behavior," "trust," "innovation," and "customer satisfaction."

Peter and Olson (2005) discuss the role of Marketing strategy as a set of stimuli that is integrated via a differing mix of strategies such as product, price, place/distribution and promotion intended to enhance consumer buying of one's goods and services. Boone and Kurtz (2003) argue that Marketing is the process of planning and executing the conception, pricing, promotion and distribution of goods and services in order to create and maintain relationship that will satisfy the customers and the companies' alike. It's successful sale of goods and services through various devices such as advertisement is evident in a big way, staring with appealing to the present and prospective customers. One has to advertise one's own virtues and bring them to the greater public notice and attention. In addition, Vitale et al. (2010), through a study, have found that 
the marketing concept is the part of the promotion mix which is vital to reach, attract and influence the target consumers in order to help the companies achieve their strategic goals.

Promotion means marketers talk to the existing customers and potential buyers to convey a message about the organization, product or some other element of the marketing mix, such as the new low price being offered during a sale period. Promotion is taking very innovative forms, for example, marketing today is picking up product brand ambassadors, who are using very innovative ways to convey the product qualities and virtues, price and other incentives for an aspiring consumer public (Ahmed and Kumar, 2016).

Product promotion is the communication to build and maintain relationships by informing and persuading one or more audiences to view an organization more positively and to accept its products. It is needless to say that promotion mixes are getting expanded from simple salesmanship to say, gifts, prizes, buy now and pay later, home free deliveries, and so on. Chitty and Barker (2005) explain the role of Sales promotion, which is often simply referred to as 'promotion' is incentive used by a manufacturer to encourage distributors, such as wholesalers, retailers or other channel members and consumer to buy a brand. It is business to business promotion which starts the chain of marketing going further to business and consumer.

Lindgern and Shimp (1996), highlight the role of personal selling as a form of person to person communication in which a salesperson works with prospective buyers and attempts to influence their purchases in the direction of his or her company's products or services. The degree to which personal selling is used by a company in its promotional mix depends on the product, selling costs, customers' needs and customers' locations. Celebrity endorsement of a brand has a direct impact on purchase intention (Singh and Banerjee, 2019). Kim and Jin (2019) explored the collaborative consumption motivations for consumer goods and identified the different dimensions for it.

Lou and Yuan (2018) study is based on the influence of social media on marketing decisions which is found to be quite substantial. The sway of social media in opinion formation regarding trustworthiness of brands is found to be considerable. The study is based on a survey of social media users, suggesting its authenticity. Maslowska et al. (2020) through a sample study of 74 on-liners tell us that online reviews can play a significant role in the consumer decision-making processes and uses eye tracking to investigate how consumers attend to product pages. The results show product-related information is most important for the consumers, who also spend time on review-related information, particularly the review text and reviewer information.

Zwanka and Bluff's, (2020) study the potential impact of the COVID-19 pandemic on global consumer traits, buying patterns, global interconnectedness and psychographic behavior, and other marketing activities by birth segments. Baby Boomers, Millennials, Centennials, show a long-term behavioral shifts due to the COVID-19 pandemic and the resulting shifts in consumer behavior in all countries. This is one of numerous studies that have been done to identify the influence of group influences such as of peer groups, opinion or reference groups, on consumer buying behavior (Solomon, 2016; Philip and Ashworth, 2020). There are studies to understand the role of marketing information on consumer buying behavior that might have been conveyed to the target consumers through different promotion mixes and external - word-of-mouth variables (McDonald and Sharp, 2000; Burnett, 
2003; Tulay, 2003; Girard and Dion, 2010); Kircher and Postlewaite, 2008; Kurtz, 2008; Peter and Olson, 2005; Ahmed, 2013 \& 2017; Khenfer, et al. 2020).

Of special interest is Sakkthivel and Sriram (2011) Omani study on acumen and risk-taking behavior of Omani entrepreneurs, which is an interesting study. Another revealing study of Sakkthivel (2011a) is on the influence of the external and internal factor on the marketing behavior of consumers in respect of consumer durables in a developing economy in Oman with $\$ 79.3$ billion GDP and $\$ 16,424$ per capital (World Bank, 2020).

The Arab region is a distinct socio-economic-cultural region, which is an economic ascendency (Ahmed and Rafiuddin, 2018). As such the extensive region's principalities like Oman appears to offer a good testing grounded for modern multi-variable marketing theory, adding to it an interesting Arab dimension. Omani's are expected to be discerning or differentiating consumers. A sample study is made of the problem under investigation with 58 consumers from whom variables-influence data was collected. The study is expected to give insight into the factors of consumer demand, not only in the Sultanate of Oman, but also the vast and Arab world in general, which occupies a strategic place in consumer marketing.

\section{Objectives and methodology}

To know the impact of promotional and non-promotional factors of demand in Omani mobile marketing, to find out the relative weightage of the factors of demand and to suggest a suitable marketing strategy for mobile marketing or variables in mobile marketing in the Sultanate of Oman.

- H1: There is a significant impact of promotional mix strategies on consumer buying behavior towards mobile communication services

- H2: There is a significant impact of External - Word of Mouth (influence of peer groups, opinion groups etc.) on consumer buying behavior towards mobile communication services.

\subsection{Research Model}

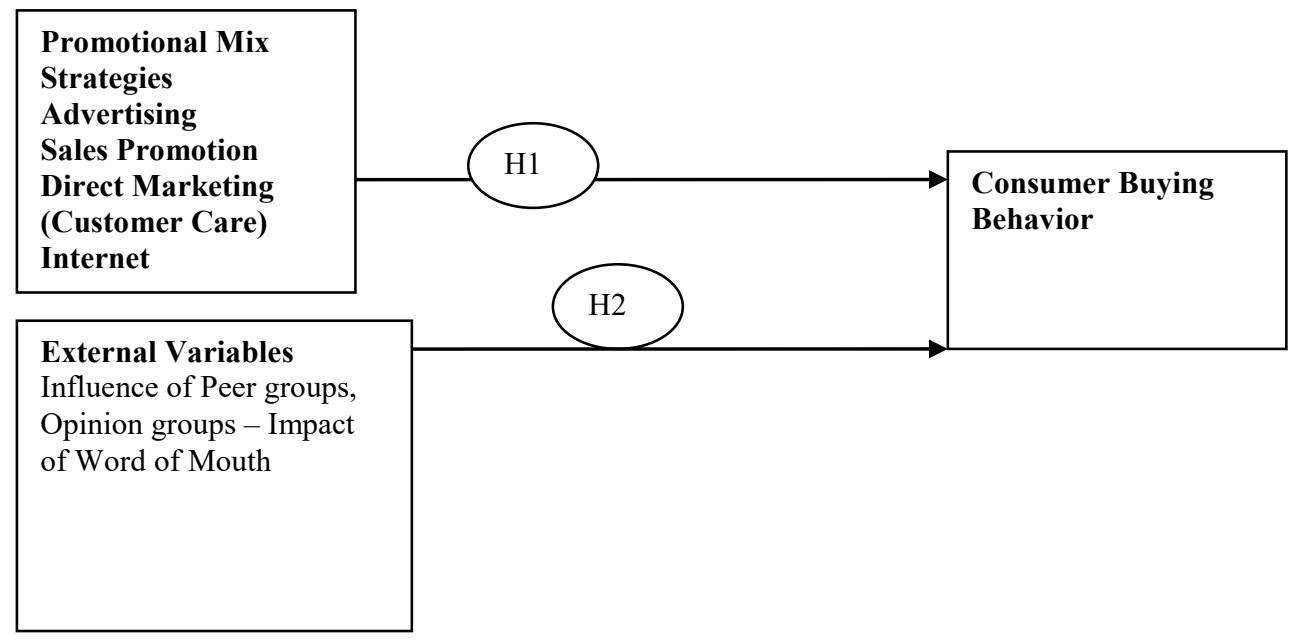




\subsection{Methodology}

The study uses the exploratory and causal research design as it explores and intends to identify the impact of promotional mix variables of advertising, sales promotion, direct marketing customer care, internet etc., variables and external variables of influence of peer groups, opinion groups - word of mouth on consumer buying behavior towards mobile communication services.

The study was conducted in Sur, Sultanate of Oman which represents the target population selected for the study. The study was conducted among students,
Sakkthivel and Sriram, 2011; Sakkthivel, 2011) to identify the high to low impact of the selected variables on consumer buying behavior towards mobile communication services. Cronbach Alpha Reliability Analysis is conducted to test the validity of the collection of the instrument data which produced a .699 response.

\section{Results}

4.1 Identification of the impact of significant impact of promotional mix strategies on consumer buying behavior towards mobile communication services

\begin{tabular}{|l|l|l|}
\hline $\begin{array}{l}\text { Promotion mix } \\
\text { variables }\end{array}$ & \\
$\begin{array}{l}\text { Advertising }(+) * \\
\text { Sales Promotion }(+) \\
\begin{array}{l}\text { Direct Marketing } \\
(\text { Customer care })(+)\end{array}\end{array}$ \\
\cline { 2 - 2 }
\end{tabular}

employees (private and govt.), businessmen etc. The quota sampling technique has been used to collect primary data from the target respondents. The primary data was collected from 58 respondents $(\mathrm{N}=58)$ who had been selected for the analysis. A structured questionnaire was used to collect the response from the target respondents. The questionnaire consisted of 5-point Likert scale responses (strongly agree.... strongly disagree). It was used to identify the impact of the promotion mix (advertising, sales promotion, direct marketing (customer care) internet etc.) variables and external variables (influence of peer groups, opinion groups - word of mouth) on consumer buying behavior towards mobile communication services. A T-Test is used to test the hypotheses and construct analysis (Sakkthivel, 2010;
${ }^{*}+/$ - denotes the positive or negative impact of the variables

One sample T-Test (2- tailed, 95\% confidence interval at $57 \mathrm{df}$ ), held to identify the impact of promotion-mix variables such as: advertising, sales promotion, direct marketing (customer care), and internet on consumer buying behavior of mobile communication services. This revealed the promotion-mix variables as follows: advertising $(p<0.05)$, sales promotion $(p<0.05)$, direct marketing (customer care) $(p<0.05)$, and internet $(p<0.05)$ are found to have first a positive (+) impact on consumer buying and decision making behaviour towards buying mobile communication services. The results in Fig-2 portray the impact of promotion-mix variables on consumer, buying and decision making behaviour, upholding 
H1.

4.2 Identification of impact of External Word of Mouth (influence of peer groups, opinion groups etc.) variables on consumer buying behavior towards mobile communication services

Fig 3: External Variables Impact on Consumer buying behaviour of mobile phones

One sample T-Test (2- tailed, 95\% bles on consumer buying and decision-making behaviour, which would provide a much-needed cue to the corporates to focus on the variables that would have high to low impact on consumer decision making. This information would help the companies to design effective promotion mix strategies, in order to reach the target consumers and influence them to make their buying decisions. Construct analysis (Sakkthivel and Sriram, 2011; Sakkthivel, 2011) is made

\begin{tabular}{|l|}
\hline External - Word of \\
Mouth Variables \\
Influence of Peer groups $(+)$ \\
Influence of Opinion groups \\
$(-)$
\end{tabular}

confidence interval at $57 \mathrm{df}$ ) held to identify the impact of external - word of mouth (influence of peer groups, reference groups consumer buying behavior towards mobile communication services influence of peer groups $(\mathrm{p}<0.05)$ is found to have a significant impact on consumer buying and decision making behaviour, whereas the influence of reference groups $(p>0.05)$ has no significant impact over consumer buying and decision making behaviour towards mobile communication services. It is evident from the results that the consumers are influenced by peer groups, however, reference groups found to elicit no influence. Thus, the results of the external variables are mixed, being positioned in respect of peer groups, but negative (-) concerning opinion groups, meaning mobile services consumers are, by and large, independent or self-dependent in their decision making.

\section{Degrees of influence}

It is imperative to understand the degrees of influence of the promotion-mix variables and external - word of mouth varia- use of to identify the high impact to low impact promotion mix and external word of mouth variables on consumer buying and decision-making behaviour towards mobile communication services in high mobile use concerning the Sultanate of Oman.

The construct analysis is done by summing up the total scores of all the variables taken to identify the impact of consumer buying behaviour and identify the mean value by dividing by total number of samples selected for the study. The sum of the mean values of all the variables pertaining to a particular construct is divided by the no. of variables pertaining to that construct viz. advertising.

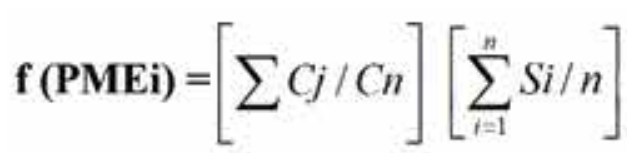

4.3 CONSTRUCT ANALYSIS MODEL 
$($ PMEi $)=$ Impact of Promotion Mix and External - Word of Mouth Variables on Consumer buying behavior

$\mathrm{Si}=$ Agreement level score of the respondents towards the influence of promotion mix and external - word of mouth variables

$\mathrm{Cj}=$ Sum of Constructs score

$\mathrm{Cn}=$ No. of constructs taken

The above model produces result of the constructs that have high to low impact values ' $i$ ' denotes the agreement level score, ' $\mathrm{j}$ ' denotes the sum of constructs scores, and ' $n$ ' denotes the number of respondents and number of constructs taken for the study and analysis. The number of questions asked is grouped into constructs such as marketing information variables. These scores are arrived at from the constructs in terms of mean values which are interpreted from the highest to the lowest values, and given ranks as $1,2,3 \ldots n$. The highest score denotes the highest impact on consumer buying behavior and so on. The sum of the mean values of constructs has been divided by the number of constructs selected for the study and the mean value arrived at was considered the midpoint. The mean values of the constructs above the mid-point are high impact variables, and vice versa. Accordingly, advertising ( $c=3.96)$ secures 1st rank, followed by Internet $(\mathrm{c}=3.86)$, Direct Marketing (Customer care) (c=3.76), Sales Promotion (c=3.72) ranking 2, $3 \& 4$. The External - Word of Mouth variables ( $c=3.33$ ) Ranked 5th in influencing consumer buying behavior towards mobile communication services.

In order to identify the high to low impact promotion-mix and external - word of mouth variables on consumer buying behavior, the sum of the mean values of constructs is divided by the number of constructs (advertising, sales promotion, direct marketing (customer care), internet, word of mouth variables) selected for the study, and the mid-point arrived at is $(\mathrm{mv}=3.72)$. The mid-point or mid value is an indicator to identify the high and low impact promotion-mix and word of mouth variables on consumer buying behavior towards using mobile communication services in Sur, in the Arab ic country of Oman, which is a member of GCC which is kin to an Arab Common Market. It is evident from the given results that the consumers are primarily influenced by advertising, internet, and direct marketing (customer care), whilst making decisions regarding mobile communication services.

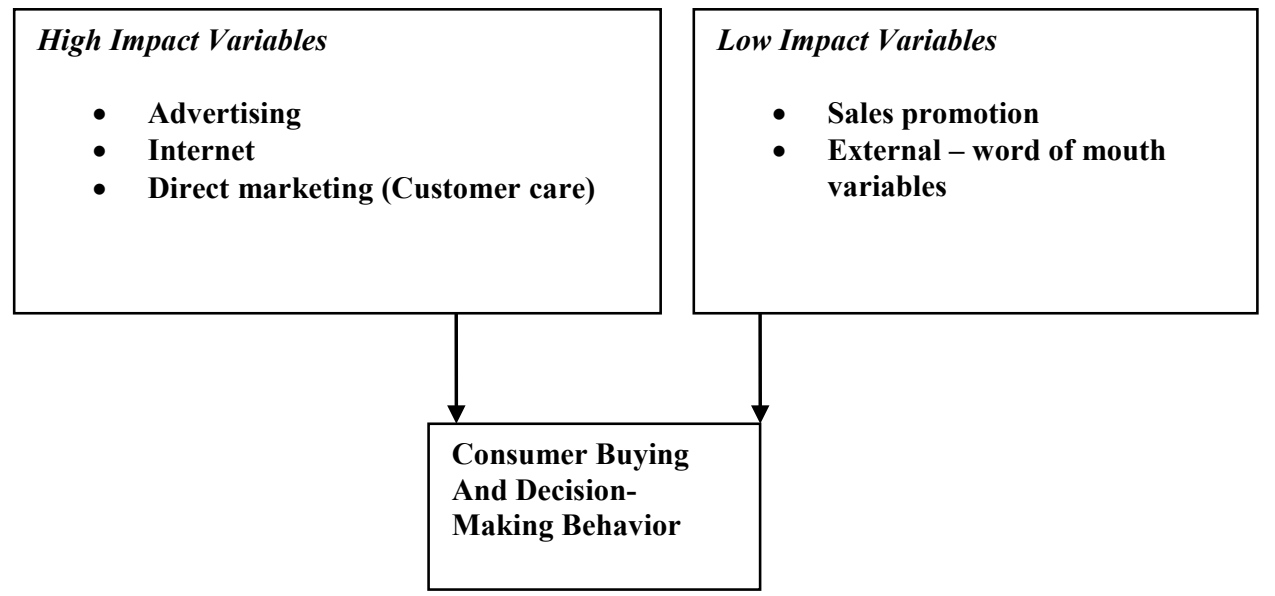

FIG 4: MODELLING OF HIGH AND LOW IMPACT PROMOTION MIX VARIABLES ON CONSUMER BUYING AND DECISION-MAKING BEHAVIOUR 
5. Conclusion and Managerial Implications

The study unearths the promotion-mix and word-of-mouth variables which have significant impact on consumer buying behavior towards various mobile communication services in Sur city of Oman, for which the exercise, which is the first of its kind, has good tidings because all advertising tools are proved to be good promotional tools. But it was surprising to notice that only few takers for peer group buying advices in mobile purchasing. This finding is not in line with, for example Solomon et al. 1999). Surprisingly, the influence of opinion groups is negative (-).

The aforesaid results provide a much needed cue to the managers on the impact of the promotion mix and external word-of-mouth variables of consumer buying behavior which, however, is of different degrees. The managers could understand the degrees of influence of the different variables on consumer buying behavior and act accordingly. There are high and low impacts promotional and word-of-mouth variables, which provide a holistic view of marketing to help the marketing managers design effective mix strategies to reach and influence target consumers using mobile communication services in Oman. In Oman, mobile use is quite wide spread, and presently, advertisement is not a mobile phone promotional measure. Advertising is making mobile products and services known through print and electronic mediums and other means. Then there is the internet as another promotional tool, with the net having made forays into every household through smart phones. These results are consistent with the results of the previous research studies of (Lindgem and Shimp 1996; Chitty and Barker, 2005; Kurtz, 2008; Lou and Yuan, 2018). In sum, there are five avenues of marketing mobile phone services in the Sultanate of Oman, namely: advertisement, net sales promotion, direct marketing, customer care, and informed peer group in the descending order of importance.

\section{Limitations and Future Research}

The study of mobile phone marketing in the Sur city of Oman is influenced by promotional and non-promotional factors bringing out some interesting and valid outcomes. It has, however, limitations of time, data, sample, space or region. It is needless to say that the dynamics of marketing change over time and space, products and services, sample, etc., which call for further research on the problem of demand determinants.

The researchers, for example, could not include indirect information variables in the study, which would have provided a comprehensive view of the problem. There are gender class, income, age, locational (Rural-Urban), educational angles to the problem, which could be the areas of research on the problem.

For example, do Brand Ambassadors sway the demand for goods and services? It is an interesting topic of future research on the problem. Thus, the field is wide open for any amount of future research. The future researchers may also attempt to test the impact of marketing information variables, individually, on consumer buying behavior, which may provide a comprehensive view.

\section{References}

Ahmed, G. (2013). "The New Global Trade Order and Retail Trade and Marketing". The Journal of Business and Retail Management Research, 7 (2) 1-12. 
Ahmed, G. and Kumar, M. (2016). "The Dynamics of Rural Marketing in the Emerging Market Economy of India", Journal of Global Business Management, 12 (1) 9-18.

Ahmed, G. (2017). "Sovereign Marketing: A New Strategy of Marketing" Theoretical Economics Letters: 44th Special Issue on Economics and Management Strategies 7 (5) 1492-1504.

Ahmed, G. and Rafiuddin, A. (2018). "Cultural Dimensions of Economic Development: A Case of UAE" Theoretical Economics Letters, Special Issue on Social Economics, 8 (11), 2479-2496.

Amponsah, C. and Ahmed, G. (2017). 'New Global Dimensions of Business Excellence'. International Journal of Business Excellence. 13 (1) 60-78.

Boone, L. and Kurtz, D. (2003). Contemporary Marketing, South Western Educational Publishing.

Burnett, J. (2003). Core Concept of Marketing, Global Text Project, USA.

Chitty, W. and Barker, N. (2005). Integrated Marketing Communication, 2nd Edition, Thomson Learning: 322 .

Girad, T. and Dion, P. (2010) "Validating the search, experience, and credence product classification framework" Journal of Business Research, $63 \quad(9 \quad \& 10)$ 1079-1089.

Khenfer, J. Shepherd, S. Trendel, O. (2020) "Customer empowerment in the face of perceived Incompetence: Effect on preference for anthroporphized brands" Journal of Business Research, 118, 1-11
Kim, N. and Jin, B. (2019). "Why buy new when one can share? Exploring collaborative consumption motivations for consumer goods", International Journal of Consumer Studies, 44 (2) 122-130

Kircher, P. and Postlewaite. A. (2008). "Strategic Firms and Endogenous Consumer Emulation", The Quarterly Journal of Economics, 123 (2) 621 - 661. Kurtz, D. (2008). Principles of Contemporary Marketing, 7th Edition, Thomson: 527.

Lindgren, J. and Shimp, T. (1996) Marketing: An Interactive Learning System, Harcourt Brace \& Company: 137.

Lou, C. and Yuan, S. (2018) "Influencer Marketing: How Message Value and Credibility Affect Consumer Trust of Branded Content on Social Media" Journal of Interactive Advertising, 19 (1) 58-73.

Macdonald, E.K. and Sharp, B.M. (2000) "Brand Awareness Effects on Consumer Decision Making for a Common, Repeat Purchase Product: A Replication" Journal of Business Research, 48 (1) 5-15.

Maslowska, E., Segin, C.M., Vakeel, K.A., Viswanathan, V. (2020) "How consumers attend to online reviews: an eye-tracking and network analysis approach" International Journal of Advertising, 39 (2) 282-306.

Nicolas, C., Valenzuela-Fernandez, L., and Merigo, J. M. (2020) "Research Marketing: A Bibliometric Study 1990-2017" Journal of Promotion Management, 26 (5) 674-703.

Peter, J. P. and Olson, J. (2005). Consumer Behavior and Marketing Strategy,7th Edition, McGraw Hill .

Philip, M. and Ashworth, L. (2020) "I 
should known better! When firm-caused failure leads to self-image concerns and reduces negative word-of-mouth" Journal of Business Research, 116, 283-293.

Sakkthivel, A.M. (2010) "Influence of internet on online buyer involvement towards buying different products and services" International Journal of Electronic Finance, 4 (2) 171-189.

Sakkthivel, A. M. and Sriram, B. (2011). "Analysis and Profiling Risk-Taking Behavior of Omani Entrepreneurs - A Case Study", (Eds.) Kakar, D., Kaur, D., and Ahuja, Y., Entrepreneurship and Innovation: New Age Mantra, 1st Edition, Excel Publishers.

Sakkthivel, A M. (2011). "Modeling the Impact of Internal and External Variables on Consumer Durables in a Matured Marketing Environment", International Journal of Electronic Finance, 5(4) 316-332.

Singh, R. and Banerjee, N. (2019) "Exploring the influence of Celebrity Worship on Brand Attitude, Advertisement Attitude, and Purchase Intention", Journal of Promotion Management, 25 (2) 225-251.

Solomon, M. R. (2016) Consumer Behavior: Buying, Having, and Being, 12th ed. Pearson.

Tulay, G. (2003). "Influence of Product Category on Consumer Information Search Behavior", Presented at DMEF's Robert B. Clarke Educator's Conference 2003. Orlando, FL.

Vitale, R., Pfoertsch, W., and Giglierano, J. (2010). Business to Business Marketing, Pearson.

World Bank (2020) Retrieved on July 05,
2020 from: https://data.worldbank.org/country/OM

Zwanka, R. J. and Bluff, C. (2020) "COVID-19 Generation: A Conceptual Framework of the Consumer Behavioral Shifts to be Caused by the COVID-19 Pandemic" Journal of International Consumer Marketing, DOI: 10.1080/08961530.2020.1771646 


\title{
THE NEXUS BETWEEN TAXATION AND NIGERIAN ECONOMIC GROWTH
}

\author{
Olufemi Samuel Adegboyo \\ Department of Economics, Faculty of Social Sciences \\ Federal University Oye-Ekiti, Ekiti State, Nigeria \\ Email: olufemi.adegboyo@fuoye.edu.ng
}

\begin{abstract}
This study investigates the relationship between taxation and economic growth in Nigeria between the periods of 1980 -2019. The study adopts the endogenous growth model as its theoretical framework. The study uses Vector Error Correction Model (VECM) and the Granger Causality estimation technique to analyze the data. The results reveal that company income tax and petroleum income tax hinder economic growth in Nigeria while personal income tax and value added tax promotes economic growth in Nigeria. The granger Causality result reveals that company income tax, value added tax and petroleum profit tax affects economic growth in Nigeria. The study recommends that government should focus more on VAT, which has no direct negative impact on company, rather enhance economic growth; also government should reduce the company income tax rate in order not to discourage investors vis-à-vis reducing company's productivity, which can deteriorate economic growth, as reveled in the study. Furthermore, Government should diversify the economy and focus less on PPT because of the volatility nature of the oil sector and consequent unreliability in using it to project revenue and expenditure.
\end{abstract}

Keywords: Taxation, economic growth, endogenous growth model, nigeria JEL Codes: H2, O4, $O 42$

\section{Introduction}

Adequate funding is required for any government to efficiently carry out its statutory functions. These functions have consistently been increasing due to the world's political and economic dynamics vis-à-vis the ever changing global economy. In addition to this, the Nigerian government is facing explosive population growth which needs to be taken care of vis-à-vis challenges associated with high population. Regrettably, the revenue of Nigeria's government has not been increasing to meet the ever increasing expenditure. The major reason for this shortfall is the mono-economy nature of the country with heavy reliance on revenue from crude oil, which is highly volatile, and its price being exogenously determined. As such Nigeria is at the mercy of foreign countries and international organizations for aid and loans to argument its income and these do come with stringent conditions which may not be completely good for the receiving economy. With the recent global financial crisis, foreign aid is not flowing as before to developing countries, including Nigeria, and this is adversely affecting different sectors of the economy. Therefore, there is a need to diversify the economy from oil by looking inward on how to finance the budget. Abomaye-Nimenibo et al. (2018) argued that taxation has been identified as one of the efficient ways of mobilizing domestic resources for economic growth globally. The need to 
focus on domestic revenue mobilization was further re-echoed by the G20 at their summit in 2010. Unfortunately, Nigeria has not fully harnessed this potential revenue as revealed by its tax quota. Tax quota is the ratio of total tax revenue to GDP and it is the most used indicator to measure tax burden. As of 2017 the tax quota of Nigeria was $5.7 \%$ which is far below the average for Africa of $17.2 \%$, Latin America Countries average of 22.8, OECD average of $34.2 \%$. This shows that Nigeria tax revenue to GDP is lower when compared to developed countries and even fell below the average of African and developing countries. This is adversely affecting the government in performing its responsibilities and spending in critical areas that would have stimulated economic growth. It is worthy of note that the Nigerian Government has been formulating different policies to improve its tax revenue among which are the tax policy reviews of 1991, 2003, 2012 and 2017, and amendments of various taxation acts in order to suit the current realities. Despite all these measures to increase tax revenue which were expected to boost economic growth via adequate funding of public expenditure, the economy has not been growing as expected as shown in Table 1.

TABLE 1: ECONOMIC INDICATORS IN NIGERIA

\begin{tabular}{|l|l|l|}
\hline Year & Tax revenue (N Billion) & GDP growth rate \\
\hline 2015 & $3,741.8$ & 2.65 \\
\hline 2016 & $3,307.5$ & -1.62 \\
\hline 2017 & $4,027.94$ & 0.81 \\
\hline 2018 & $5,320.52$ & 1.94 \\
\hline 2019 & $5,263.1$ & 1.58 \\
\hline
\end{tabular}

This study is designed to determine the actual effect of tax on economic growth. Furthermore, there are empirical evidences on how taxation affects economic growth as researchers like Gashi et al. (2018), Babatunde et al. (2017), Chimilila (2018), and Vatavu, Lobont, Stefea and Brindescu-Olariu (2019) argue that taxation positively affect economic growth, while Khumbuzile and Khobai (2018), and Macek (2014), stated that economic growth was adversely affected by increment in taxation. Michael and Friday (2018), Ilaboya and Mgbame (2012) concluded that taxation had no impact on economic growth. Given the controversies surrounding how taxation affects economic growth this study will investigate the way in which taxation has been affecting economic growth in Nigeria between 1980 and 2019. The study will make use of Company Income Tax, Personal Income Tax, Petroleum Profit Tax, Value Added Tax, human capital and gross capital formation as the explanatory variables while real Gross Domestic Product would be the dependent variable. The data is sourced from Federal Inland Revenue Service and World Bank indicator. The statistical tool to be used for this study is E-view 10 while the data would be analyzed with VECM and Granger Causality Test. The remaining part of this paper is structured as follow: section 2 is all about literature review, section 3 describes the methodology which consist of theoretical framework and model specification, section four presents the data analysis, and lastly section 5 consist of summary and policy recommendations.

\section{Literature review}

The origin of tax in Nigeria can be traced to 1904 when community tax was introduced in the Northern Nigeria, this was even before the amalgamation of the country in 1914 Ola (2001). This was later implemented in 1917 and 1921 in Western and Eastern region respectively Odusola (2006). Taxation is defined as a process of collecting taxes while tax is the compulsory monetary burden imposed by the government against its citizens to support in funding public expenditure. In Nigeria taxes are being levied on individual, assets, corporate entities and transaction. The National tax policy of 2012 spilt taxes being levied on Nigerian citizens on the following bases: 
(i) individual's bases: personal income tax and development levy;

(ii) assets bases: property tax;

(iii) corporate entities bases: company income tax, education tax, technology level and petroleum profit tax; and

(iv) transactions bases: value added tax, capital gain tax, stamp duty, import duty and export duty.

Taxes has enormous important to the economy and this cannot be over-emphasized, some of the benefit of tax to the economy are: first, revenue generated from taxes can be used to develop other sector of the economy where government can generate more funds; second, it can also be used to redistribute income in favor of the poor; third, revenue generated from taxes can be used to provide social security to the indigents and poor of poor; fourth, revenue generated from taxes can be used to stimulate sectors that can create more jobs to the populace and create wealth for the junk majority of the citizens and develop the economy; fifth, revenue generated from taxes can be used to stimulate economic growth by using the revenue realized from it to provide basic infrastructure that can attract investors such as electricity, road and transportation; and lastly, revenue generated from taxes can be used to strengthen financial institutions and develop effective regulatory system. Despite these benefits of tax to the economy, the tax revenue that have usually been realized in Nigeria are always short of target and this has been adversely affecting the implementation of the annual budget and economic growth in Nigeria. The reason for this low tax revenue are summarized below: First, high rate of tax avoidance and evasion coupled with lopsided tax laws vis-à-vis poor enforcement of the law due to limited manpower in tax administration in Nigeria. Second, the percentage of informal sector is higher than that of formal sector and in an informal sector there is improper record of profit generat- ed on which tax would be based, also they have limited revenue potential so less tax can be generated as such the country tax base is narrow, i.e. the few working in formal sector pays the bulk of the government revenue tax. Third, lack of social truth on the government, citizens don't want to pay tax because of the fear that the fund would not be efficiently utilized or even embezzled. Corruption has been one of the menaces that is affecting Nigeria society as the country is rated the thirty-third most corrupt country in the world. Lastly, the high rate of tax exemption giving to investors has been reducing the expected tax revenue. This is reported by Van Parys and James (2009) and joint report by the IMF, OECD, UN and the World Bank (2011). IFC investor surveys reveals that tax incentives are not sufficient to attract investment to countries, rather a favorable investment climate, skills vis-à-vis market size and good governance does. Therefore, the tax incentives given are not necessary, rather it gives room for bribery and corruption in the tax administrative system Zee et al. (2002), and Fjeldstad and Semboja (2001).

Even though taxation is good for the economy as explained previously, Marina (1999), and Engen and Skinner (1996) are of the view that higher taxes do have adverse effect on the economy growth. They gave five ways through which tax do negatively affect economic growth as highlighted below:

First, higher tax can distort investment i.e. an increase in the statutory tax rate for income tax, corporate tax and capital gain tax would discourage investment. Second, higher tax can dwindle labor supply growth by discouraging workers from increasing their input and they will prefer leisure to work. Third, it can dissuade productivity growth when expenditure on research and development, that could lead to innovation and technological advancement, has been reduced Forth, tax can affect marginal 
productivity of capital when investors from highly taxed sectors to lower taxed sectors thereby lowering overall economic productivity. Fifth, high taxes on labor can distort the efficient use of human capital as labor would not be seeking employment in sectors with high tax, even when the sector has higher social productivity.

Empirical review on developed countries Using a panel data, Stoilova and Patonov (2012) investigated the impact of tax on 27 European Union member countries between 1995 and 2010, the result showed that direct tax contributed to economic growth. Likewise, Vatavu et al. (2019), explored how tax affects welfare gain and economic growth in the 7 richest European countries and 7 Central and Eastern Europe Countries. Using the Granger Causality Test, the study showed that taxes contributes positively to economic. Similarly, Tosun and Abizadeh (2005), in their study of OECD countries between 1980 and 1999 using fixed effect random estimation technique, found that personal tax and property tax had positive impacts on economic growth while corporate tax and international trade tax had no significant impact on economic growth.

Conversely, Macek (2014) investigated the impact of tax on OECD countries using panel dataset between the period of 2000 and 2011. Macek found that personal income tax, corporate tax and social security contribution adversely affects economic growth. Likewise, Dackehag and Hansson (2012), in their study of 25 rich OECD countries between the periods 1975 - 2010 found that personal income tax and corporate tax inhibits economic growth. Furthermore, Hakim, Karia and Bujang (2016), used Arellano-Bond dynamic panel GMM estimation technique to investigate the impact of goods and service tax on economic growth in developing and developed countries between 2005 and 2012. Their study revealed that goods and services tax had negative impact on economic growth of developing countries, but had positive impact on economic growth of developed countries.

Empirical review on developing countries Canavire-Bacarreza et al. (2013), in their work, examined the relationship between taxation and economic growth in Latin America using generalized method of moments (GMM) estimation technique found that personal income tax, corporate tax and consumption tax contributed positively to economic growth. Also, Babatunde et al. (2017) investigated how taxation affected economic growth in African countries from 2004 to 2013 using the panel estimation technique; they found that tax revenue promoted economic growth. Furthermore, Chimilila (2018) examined the long-run effect of domestic resource mobilization (tax) on economic growth in Tanzania between 1996 and 2015 using the Autoregressive Distributed Lag (ARDL) estimation technique. He found that domestic resource mobilization (tax) enhanced economic growth in the long-run. Similarly, in their study of the impact of tax revenue on economic growth in Nigeria and Ghana between 2000 and 2016 using multiple regression estimation technique, Egbunike et al. (2018) revealed that tax revenue had positive impact on economic growth. In addition, Gashi et al. (2018), investigated the impact of tax structure on the economic growth of Kosovo between the period of 2007 and 2015 using Ordinary Least Squares (OLS) analytical tool, the study revealed that tax positively influence economic growth.

Contrariwise, Khumbuzile and Khobai (2018) investigated the effect of taxation on economic growth of South Africa between 1981 and 2916 using Auto-Regressive Distribution Lag (ARDL) estimation technique and found that taxes hampered economic growth. Using 
Ordinary Least Square technique to investigate the effect of tax on Kenya's economic growth from 1973 to 2010, Owino (2019) found that Customs Duty (CD) and Excise Duty (ED) instigated economic growth while income tax (IT), and Value Added Tax (VAT) are insignificant to economic growth.

Empirical review on Nigeria

Umoru and Anyiwe (2013) in their study investigated the relationship between tax structure and economic growth in Nigeria between the period of 1988 and 2011 using Johansen's co-integration estimation technique. They found that direct tax contributed positively to economic growth while indirect tax deterred economic growth. Furthermore, Onakoya and Fintinni (2016) examined the relationship between tax revenue and economic growth in Nigeria between 1980 and 2013 using Vector Error Correction Model (VECM). They found that petroleum profit tax and company income tax positively influence economic growth while customs and excise duties inhibit economic growth. Also, Uzoka \& Chiedu (2018) explored the impact of tax revenue on economic growth in Nigeria from 1997 to 2016 using Vector Error Correction Mechanism (VECM) estimation technique, the study showed that PPT, CIT, VAT and CED positively influenced economic growth, while CGT and EDT had no impact on economic growth.

Abomaye-Nimenibo et al. (2018), explored how tax affect economic growth between the period of 1980 and 2015 using Johansen co-integration model. They found that company income tax, petroleum profit tax and custom and excise duties did not affect economic growth. This was a similar result to Ilaboya and Mgbame (2012) in their study to determine the impact of tax on economic growth in Nigeria between the period of 1980 and 2011 using Autoregressive Distributed Lag (ARDL) estimation technique. They found that indirect tax has no impact on economic growth.

\section{Methodology}

Theoretical framework

Endogenous growth model is a conglomeration of various theoretical and empirical work and it came into being in the 1980's, Romer (1994). The model opposed the neoclassical growth theory which argued that long run economic growth is been influenced by external influence i.e. technology spillover and population growth. Endogenous growth model is of the view that economic growth is determined by the system governing the production process rather than by forces outside that system, Todaro and Smith (2012). The Endogenous growth theory states that the changes in technology which affects economic growth are a result of education, training and investment in research by private investors vis-à-vis government. Furthermore, the theory explains how government policies encourage incentives to enhance both human and physical capital which often lead to economic growth. Thus the theory explains how changes in government policies can influence output and how innovation via investments in human and physical capital can foster economic growth. Mahir and Azra (2017), state that this theory made fiscal policy a crucial field of study of economic growth by incorporating tax and expenditure as long-run determinate of growth. The model classified tax into distortionary and non-distortionary tax. Distortionary tax are taxes that dissuade investment which consequently reduce economic growth while non-distortionary tax does not discourage investment and therefore has no adverse effect on economic growth.

Model specification

This study patterns its model specification in line with the theoretical framework.

$\mathrm{Y}=\mathrm{AK}$ 
(1) Where Y means output, A, means factors that affects technology and $\mathrm{K}$ implies both physical and human capital. Introducing the tax variable into the Equation 1 above leads to the model this study uses as specified in Equation 2 below.

RGDP = f (CIT, PIT, PPT, VAT, SSER, GCF).

(2) $\mathrm{RGDP}=$ B_0+B_1 CIT + B_2 PIT $+B \_3$ $\mathrm{PPT}+6 \_4 \mathrm{VAT}+\mathrm{B} \_5 \mathrm{HUC}+\mathrm{B} \_6 \mathrm{GCF}+\mu \_\mathrm{t}$

(3)Where: RGDP: Real Gross Domestic Product

CIT: Company Income Tax

PIT: Personal Income Tax

PPT: Petroleum Profit Tax

VAT: Value Added Tax

HUC: Proxy by secondary school enrolment rate

GCF: Gross Capital Formation.

$\mu \_\mathrm{t}=$ error term.

Equation 3 below is the econometrics form of equation 2 :

RGDP_t $=6 \_0+B \_1(\mathrm{CIT}) \_\mathrm{t}+\mathrm{B} \_2(\mathrm{PIT}) \mathrm{t}+\mathrm{B}$ _3 (PPT)_t+B_4 (VAT)_t+ B_5 (HUC)_t+ B $-6(\mathrm{GCF})+\mu \_\mathrm{t}$

(4) The variables were log and the logged model is presented below.

(5) InRGDP_t=B_0+ $\left(\operatorname{In} B \Omega \_1\right.$ (CIT) $t+t$ $\mathrm{In} B \rrbracket \_2(\mathrm{PIT}) \_\mathrm{t}+\llbracket \operatorname{In} B \rrbracket \_3(\mathrm{PPT}) \_\mathrm{t}+\llbracket \mathrm{In}$ B)_4 (VAT)_t+ 【InB】_5 (HUC)_t+ InB _6 (GCF)_t+ $\mu \_t$

\subsection{Apriori expectation}

All the variables are expected to have a positive relationship with economic growth.

TABLE 2: SUMMARY OF DESCRIPTIVE ANALYSIS

\begin{tabular}{|l|l|l|l|l|l|l|l|}
\hline Variables & $\begin{array}{l}\text { LOG(RG } \\
\text { DP) }\end{array}$ & $\begin{array}{l}\text { LOG(CI } \\
\text { T) }\end{array}$ & $\begin{array}{l}\text { LOG(GC } \\
\text { F) }\end{array}$ & $\begin{array}{l}\text { LOG(PI } \\
\text { T) }\end{array}$ & $\begin{array}{l}\text { LOG(PP } \\
\text { T) }\end{array}$ & $\begin{array}{l}\text { LOG(HU } \\
\text { C) }\end{array}$ & $\begin{array}{l}\text { LOG(VA } \\
\text { T) }\end{array}$ \\
\hline Mean & 10.276 & 3.496 & 7.479 & 4.425 & 5.098 & 3.416 & 3.538 \\
\hline Std. Dev. & 0.573 & 2.804 & 1.889 & 1.783 & 2.626 & 0.311 & 2.498 \\
\hline Skewness & 0.335 & -0.248 & -0.292 & -0.163 & -0.233 & -0.016 & -0.118 \\
\hline Kurtosis & 1.588 & 1.589 & 1.682 & 1.721 & 1.458 & 2.718 & 1.553 \\
\hline Jarque-Bera & 4.071 & 3.728 & 3.462 & 2.902 & 4.325 & 0.135 & 3.579 \\
\hline Probability & 0.131 & 0.155 & 0.177 & 0.234 & 0.115 & 0.935 & 0.167 \\
\hline Observations & 40 & 40 & 40 & 40 & 40 & 40 & 40 \\
\hline
\end{tabular}

The Table 2 below shows the summary of the descriptive analysis. The estimated mean which is being used to evaluate the pattern of distribution revealed that real gross domestic product recorded the highest with the value of 10.276 while Human Capital recorded the lowest with the value of 3.416. The standard deviation which do reveal the volatility of variables showed that company income tax is the most volatile variable, while Human Capita is the least. The skewness statistics indicated that only real gross domestic product is positively skewed while other variables were negatively skewed. The Kurtosis statistics revealed that all the variables under study are mesokurtic. The Jarque-Bera statistic showed that the null hypothesis of normal distribution was rejected for all the variables at $5 \%$ critical value. 
TABLE 3: UNIT ROOT TEST RESULT

\begin{tabular}{|l|l|l|l|l|l|}
\hline & \multicolumn{2}{|l|}{ ADF } & \multicolumn{2}{l}{ P-P } & \multirow{2}{*}{$\begin{array}{l}\text { LEVEL OF } \\
\text { INTEGRATION }\end{array}$} \\
\cline { 1 - 5 } VARIABLE & Level & First Diff. & Level & First Diff. & \\
\hline LOG(CIT) & -1.255 & $-5.575^{* *}$ & -1.403 & $-10.294^{* *}$ & $\mathrm{I}(1)$ \\
\hline LOG(GCF) & -1.559 & $-9.174^{* *}$ & -1.511 & $-16.454^{* *}$ & $\mathrm{I}(1)$ \\
\hline LOG(PIT) & -0.966 & $-4.776^{* *}$ & -0.962 & $-4.774^{* *}$ & $\mathrm{I}(1)$ \\
\hline LOG(PPT) & -1.391 & $-5.542^{* *}$ & -1.679 & $-5.584^{* *}$ & $\mathrm{I}(1)$ \\
\hline LOG(HUC) & -0.335 & $-6.365^{* *}$ & -0.335 & $-6.359^{* *}$ & $\mathrm{I}(1)$ \\
\hline IN(VAT) & -0.787 & $-4.482^{* *}$ & -0.787 & $-4.363^{* *}$ & $\mathrm{I}(1)$ \\
\hline INRGDP & -0.667 & $-3.934^{*}$ & -0.166 & $-3.958^{*}$ & $\mathrm{I}(1)$ \\
\hline
\end{tabular}

This study conducts Unit Root Test to determine the stationarity of each variable. This is done because most time series data are assumed to be non-stationary and when regression analysis is conducted on a non-stationary variable, it gives spurious or nonsense regression (Gujarati 2011). This study made use of ADF and Philip Peron (P-P) test to conduct the stationarity test. The two method were used to get a more accurate stationarity of each variable. The summary of the test is presented below in Table 3.
The result from both $\mathrm{AD}$

F and P-P Unit Root Test as displayed above show that all the time series data being used in this study are integrated of order one I(1). Therefore, this study will make use of Vector Error Correction Model (VECM) estimation technique as the requirement for its usage has been met.

\subsection{Lag length selection.}

Having established the estimation technique to be used, it is logical to determine the optimum lag length to be used before proceeding to the test. Therefore, lag selection criterion would be conducted to determine the optimum lag length for the model. This study used AIC criterion.

TABLE 4: LAG LENGTH SELECTION RESULT

\begin{tabular}{|l|l|l|l|l|l|l|}
\hline Lag & LogL & LR & FPE & AIC & SC & HQ \\
\hline $\mathbf{0}$ & -106.201 & NA & $1.27 \mathrm{e}-06$ & 6.289 & 6.597 & 6.396 \\
\hline $\mathbf{1}$ & 99.115 & 319.381 & $3.78 \mathrm{e}-11$ & -2.963 & $0.467^{*}$ & -3.162 \\
\hline $\mathbf{2}$ & 158.330 & $73.999^{*}$ & $4.08 \mathrm{e}-13^{*}$ & $-5.526^{*}$ & 1.247 & $-9.868^{*}$ \\
\hline $\mathbf{3}$ & 253.471 & 71.264 & $3.29 \mathrm{e}-10$ & -2.395 & 1.656 & -1.536 \\
\hline $\mathbf{4}$ & 436.722 & 69.084 & $2.27 \mathrm{e}-10$ & -1.946 & 2.238 & -1.351 \\
\hline
\end{tabular}


TABLE 5: RESULT OF JOHANSEN CO-INTEGRATION TEST

\begin{tabular}{|l|l|l|l|l|l|}
\hline $\begin{array}{l}\text { Hypothesized } \\
\text { No. of CE(s) }\end{array}$ & Eigenvalue & $\begin{array}{l}\text { Trace } \\
\text { Statistic }\end{array}$ & $\begin{array}{l}\mathbf{5 \%} \\
\text { Critical } \\
\text { Value }\end{array}$ & $\begin{array}{l}\text { Max- } \\
\text { Sigen } \\
\text { Statistic }\end{array}$ & $\begin{array}{l}\text { 5\% Critical } \\
\text { Value }\end{array}$ \\
\hline None & 0.932 & $293.368^{*}$ & 125.615 & $99.489 *$ & 46.231 \\
\hline At most 1 & 0.854 & $193.878^{*}$ & 95.754 & $71.307 *$ & 40.078 \\
\hline At most 2 & 0.762 & $122.571 *$ & 69.819 & $53.057 *$ & 33.877 \\
\hline At most 3 & 0.628 & $69.514^{*}$ & 47.856 & $36.607 *$ & 27.584 \\
\hline At most 4 & 0.412 & $32.906 *$ & 29.797 & 19.669 & 21.131 \\
\hline At most 5 & 0.229 & 13.237 & 15.494 & 9.667 & 14.264 \\
\hline At most 6 & 0.092 & 3.57 & 3.841 & 3.57 & 3.841 \\
\hline
\end{tabular}

*indicates lag order selected by the criterion.

From the above table the optimum lag using AIC criterion is 2, therefore, this study would be using lag 2 in the estimation technique.

4.4 Johansen Co-integration test, Having identified the optimal lag length, the next thing is to determine if there is cointegration in the model using the Johansen Co-integration test.

The null hypothesis is that there is no co-integration in the model and, where there is asterisk, we shall reject the null hypothesis that the variables are not co-integrated at 5\% significant level and accept the alternative hypothesis that there is co-integration. Trace test shows that there is five co-integrating equation while the Maximum Eigenvalue shows that there are four co-integrating equation. In sum, the test reveals that there is co-integrating relationship in the model and that there is a long-run relationship between economic growth on one hand and company income tax, gross capital formation, personal income tax, petroleum income tax, human resources and value added tax on the other hand.

Due to the normalization process, the normalized co-integration coefficient signs are always being reverse to enable proper interpretation of the model.

TABLE 6: NORMALIZED CO-INTEGRATING COEFFICIENTS

\begin{tabular}{|l|l|l|l|l|l|l|}
\hline LOG(RGDP) & LOG(CIT) & LOG(GCF) & LOG(PIT) & LOG(PPT) & LOG(SSER) & LOG(VAT) \\
\hline 1.000 & -4.346 & 40.061 & 1.719 & -24.004 & 32.389 & -5.029 \\
\hline & $(3.538)$ & $(3.432)$ & $(2.663)$ & $(2.392)$ & $(5.909)$ & $(3.766)$ \\
\hline
\end{tabular}


Table 6 shows that company income tax, petroleum profit tax and value added tax positively influence economic growth in Nigeria, while gross capital formation, personal income tax and human capital adversely affects economic growth in Nigeria. 4.6 VECM regression of taxation and economic growth

R-square: 0.678; Adj. R-square: 0.589; SSR: 0.021; SSE: 0.027; F-stat.: 7.619; LL: 88.418; AIC:-4.179; SC: -3.792;

$\Delta\left[\mathrm{LOG}(\mathrm{RDGP}) \rrbracket_{-} \mathrm{t}=-0.343\right.$ [ECT $\rrbracket$

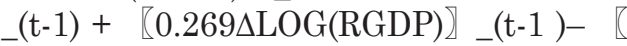
$0.019 \Delta \mathrm{LOG}(\mathrm{CIT})]_{-}(\mathrm{t}-1)+{ }^{-} \mathrm{C} 0.0403 \Delta$ $\mathrm{LOG}(\mathrm{GCF})]_{-}(\mathrm{t}-1)+[0.062 \Delta \mathrm{LOG}(\mathrm{PIT})$ $\Sigma_{-}(\mathrm{t}-1)-[0.012 \Delta \mathrm{LOG}(\mathrm{PPT}))_{-}(\mathrm{t}-1)+\varangle$ $0.117 \Delta \mathrm{LOG}(\mathrm{HUC})]_{-}(\mathrm{t}-1)+\llbracket 0.002 \Delta$ LOG(VAT) $]_{-}(\mathrm{t}-1)+0.021$

The error correction term is well defined as it is negative and significant as the t-statistic is greater than two. The co-efficient is -0.343 which implies that $34.3 \%$ previous periods deviation from the long run equilibrium in economic growth is been corrected by GCF, PIT, PPT, SSER and VAT within one period.

The above result further revealed that company income tax has a negative significant effect on Nigeria economic growth in the short run, i.e. a percent increase in the previous year of CIT would lead to $0.019 \%$ decrease in RGDP on the current year.

This implies that, as company income tax increases, the profit after tax, which is supposed to be used to expand the company, declines and this in turn adversely affects economic growth in Nigeria. This is in accordance with the work of Dackehag and Hansson (2012), but does not conform to the apriori expectation.

Conversely, gross capital formation has a positive significant influence on Nigeria economic growth in the short run i.e. a percent increase in the previous year of GCF would lead to $0.0403 \%$ increase in RGDP on the current year. This means that that the more fixed assets are being acquired by the country the more the economy grows in Nigeria. This conform to the apriori expectation.

TABLE 7: ERROR CORRECTION MODEL RESULT

\begin{tabular}{|l|l|l|l|}
\hline variable & $\mathrm{D}($ LOG(RGDP)) & Standard errors & t-statistics \\
\hline CointEq & -0.343 & 0.01 & 4.129 \\
\hline $\mathrm{D}($ LOG(RGDP(-1))) & 0.269 & 0.131 & 2.047 \\
\hline $\mathrm{D}($ LOG(CIT(-1))) & -0.019 & 0.009 & -2.107 \\
\hline $\mathrm{D}($ LOG(GCF(-1))) & 0.0403 & 0.008 & 4.733 \\
\hline $\mathrm{D}($ LOG(PIT(-1))) & 0.062 & 0.017 & 3.641 \\
\hline $\mathrm{D}($ LOG(PPT(-1))) & -0.012 & 0.012 & -1.001 \\
\hline $\mathrm{D}($ LOG(HUC(-1)) $)$ & 0.117 & 0.557 & 2.109 \\
\hline $\mathrm{D}($ LOG(VAT(-1)) $)$ & 0.002 & 0.019 & 0.093 \\
\hline C & 0.021 & 0.008 & 2.396 \\
\hline
\end{tabular}


Furthermore, personal income tax has a positive significant influence on Nigerian economic growth in the short run, i.e. a percent increase in the previous year of PIT would lead to $0.062 \%$ increase in RGDP in the current year. This implies that, as more revenue are being generated through personal income tax and the revenue are being used for developmental projects, the economic grows. This is in agreement with the work of Tosun and Abizadeh (2005) and conform to the apriori expectation.

Petroleum profit tax had no significant impact on economic growth in Nigeria. This could be because of the volatility in

the oil sector for instance when the expected oil revenue is being used to project government expenditure and there is a shock in the sector the proposed project may not be executed. Therefore, petroleum profit tax is not a reliable source of revenue. This is in agreement with the work of Abomaye-Nimenibo et al. (2018) but does not conform to the apriori expectation.

Human Capital positively and significantly affects economic growth in Nigeria in the long-run, i.e. a percent increase in the previous year of HUC would lead to $0.117 \%$ increase in RGDP on the current year. This conform to the apriori expectation.

\section{TABLE 8: PAIRWISE GRANGER CAUSALITY RESULT}

\begin{tabular}{|l|l|l|l|}
\hline Null Hypothesis & Obs. & F-Statistic & Prob. \\
\hline LOG(CIT) does not Granger Cause LOG(RGDP) & 39 & 13.019 & 0.001 \\
LOG(RGDP) does not Granger Cause LOG(CIT) & & 1.405 & 0.244 \\
\hline LOG(GCF) does not Granger Cause LOG(RGDP) & 39 & 12.964 & 0.009 \\
LOG(RGDP) does not Granger Cause LOG(GCF) & & 5.108 & 0.030 \\
\hline LOG(PIT) does not Granger Cause LOG(RGDP) & 39 & 0.753 & 0.391 \\
LOG(RGDP) does not Granger Cause LOG(PIT) & & 2.044 & 0.161 \\
\hline LOG(PPT) does not Granger Cause LOG(RGDP) & 39 & 17.167 & 0.002 \\
LOG(RGDP) does not Granger Cause LOG(PPT) & & $6.1 \mathrm{E}-05$ & 0.994 \\
\hline LOG(HUC) does not Granger Cause LOG(RGDP) & 39 & 1.429 & 0.239 \\
LOG(RGDP) does not Granger Cause LOG(HUC) & & 9.741 & 0.004 \\
\hline LOG(VAT) does not Granger Cause LOG(RGDP) & 39 & 18.147 & 0.001 \\
LOG(RGDP) does not Granger Cause LOG(VAT) & & 0.793 & 0.379 \\
\hline
\end{tabular}

Lastly, value added tax enhance economic growth in Nigeria in the short run i.e. a percent increase in the previous year of VAT would lead to $0.002 \%$ increase in RGDP on the current year. This implies that as more revenue are being realized through VAT, the economic grows. This is in tandem with the work of Uzoka \& Chiedu (2018), and conform to the apriori expectation.

\subsection{Causality Test}

A causality test is conducted to examine causal relationship between two variables. There are different methods of investigating causal relationship, however, this study will make use of the Pairwise Grang

er Causality Test. The null hypothesis is that there is no causal relationship between the two and the alternative hypothesis is that there is causal relationship between the two variables. The null hypothesis would be accepted if the probability value is more than $5 \%$, however, if the probability value is equal or less than $5 \%$ we reject the null hypothesis and accept the alternative hypothesis.

The Pairwise Granger causality result is present in the table 6 below. The result reveals the following: (i) there is uni-directional causality from CIT to RGDP, i.e. company income tax affects economic growth in Nigeria. (ii) there is bi-directional causality between GCF and RGDP, i.e. gross capital formation affects economic growth in Nigeria vice-versa. (iii) There is uni-directional causality from PPT to RGDP, i.e. petroleum profit tax significantly affects economic growth in Nigeria. (iv) There is uni-directional causality from RGDP to HUC, i.e. economic growth in Nigeria affects Human capital. (v) There is uni-directional causality from VAT to RGDP, i.e. value added tax has an impact on economic growth in Nigeria. 


\subsection{Diagnosis Tests}

Diagnosis tests or post estimate test were conducted to determine how reliable the estimates results are. This study conducted three diagnosis tests namely: VEC Residual Heteroskedasticity Tests, VEC Residual Normality Tests and VEC Residual Serial Correlation LM Tests.

TABLE 9: DIAGNOSIS TEST RESULT

\begin{tabular}{|l|l|l|l|}
\hline & Chi-sq & DF & Prob. \\
\hline VEC Residual Heteroskedasticity Tests & 474.871 & 448 & 0.1834 \\
\hline VEC Residual Normality Tests: & & & \\
Skewness & 61.807 & 7 & 0.328 \\
Kurtosis & 272.249 & 7 & 0.253 \\
Jarque-Bera & 334.057 & 14 & 0.487 \\
& & & \\
\hline $\begin{array}{l}\text { VEC Residual Serial Correlation LM } \\
\text { Tests }\end{array}$ & 38.700 & 49 & 0.854 \\
\hline
\end{tabular}

A VEC Residual Serial Correlation LM test was conducted to determine if there is serial correlation in the model. The null hypothesis is that there is no serial correlation in the model and this would be accepted when the probability value is greater than $0.05 \%$, otherwise we accept the alternative hypothesis. The result shows that the probability value is higher than

$0.05 \%$ therefore we accept the null hypothesis that there is no serial correlation or autocorrelation in the model.

A VEC Residual Normality Tests was conducted using Skewness, Kurtosis and Jarque-Bera to determine if the variables are normally distributed. The null hypoth

esis is that the residuals are multivariate normally distributed and this would be accepted when the probability value is greater than $0.05 \%$ otherwise we accept the alternative hypothesis. The result shows that the probability value is higher than $0.05 \%$ therefore we accept the null hypothesis that the residual is multivari- ate normally distributed.

A VEC Residual Heteroskedasticity Test was conducted to determine if the variables are Heteroskedasticity. The null hypothesis is that the residuals are not Heteroskedasticity and this would be accepted when the probability value is greater than $0.05 \%$ otherwise we accept the alternative hypothesis. The result shows that the probability value is higher than $0.05 \%$ therefore we accept the null hypothesis that the residuals are not Heteroskedasticity rather they are Homoskedastic.

\section{Summary}

This study investigated the relationship between tax structures on economic growth in Nigeria between the periods of 1980 - 2019. The study adopted the endogenous growth model as its theoretical framework and specified its model is consistent with the theory. The study made use of the Vector Error Correction Model (VECM) and Granger Causality estimation technique to analysis the data. The result revealed that company income tax and petroleum income tax had an adverse effect on the economy in Nigeria while personal income tax, value added tax, human capital and gross capital formation promotes economic growth in Nigeria. The Granger Causality that shows the direction of causality reveal that company income tax, value added tax and petroleum profit tax affects economic growth in Nigeria, gross capital formation affects economic growth in Nigeria and economic growth affects human capital in Nigeria.

Based on the findings, the study recommends the following policy formulation for economic growth in Nigeria:

1. Government should diversify the economy and focus less on PPT because of the 
volatility nature of the oil sector and consequent unreliability in using it to project revenue and expenditure.

2. Government should intensify efforts to capture and ensure payment of income tax by the informal sector which employs more than $50 \%$ of the total labor force in Nigeria as personal income tax promotes economic growth.

3. Government should focus more on VAT which has no direct negative impact on companies rather enhances economic growth and also gives some concessions to company income tax to reduce its adverse effect on the companies and, in turn, deteriorates economic growth as reveled in the study.

4. Government should formulate policies that would encourage human capital development as it enhances economic growth.

\section{References}

Nimenibo, A., Samuel, W. A., Eyo, M. J. \& Chika, H. (2018). An Empirical Analysis of Tax Revenue and Economic Growth in Nigeria from 1980-2015. Global Journal of Human Social Science: F Political Science, 18(3), 8-36.

Babatunde A., Ibukun, O. \& Oyeyemi, G. (2017). Taxation revenue and economic growth in Africa, Journal of Accounting and Taxation, 9(2), 11-22.

Canavire-Bacarreza et al. (2013). Taxation and economic growth in Latin America. Inter-American Development Bank working paper series No IDB-WP-431.

Chimilila C. (2018). Domestic resource mobilization and long term economic growth in Tanzania, African Journal of Economic Review, (VI) I, 142-159.

Dackehag, M. \& Hansson, A. (2012). Taxation of Income and Economic Growth:
An Empirical Analysis of 25 Rich OECD Countries. OECD Department Working Paper No. 20, pp.126.

Engen, E. M. \& Skinner, J. (1996). Taxation and economic growth. National tax journal vol.49 no.4 617-649

Egbunike, F. C., Emudainohwo, O. B., \& Gunardi, A. (2018). Tax revenue and economic growth: A study of Nigeria and Ghana. Signifikan: Jurnal Ilmu Ekonomi. 7 (2): 213 - 220. doi: http//dx.doi.org/10.15408/sjie. v7i2.7341.

Federal Ministry of Finance (2012), National Tax Policy, Federal Republic of Nigeria

Fjeldstad, O.-H, and Semboja J. (2001). Why people pay taxes: The case of the development levy in Tanzania'. World Development, 29, 2059-74

Gashi B., Asllani G., \& Boqolli L. (2018). The effect of tax structure in economic growth. International Journal of Economics and Business Administration (VI) 2, 56-67

Hakim, T. A. (2016). Does goods and services tax stimulate economic growth? International evidence. Journal of Business and Retail Management Research, 10(3).

Ilaboya, O. J. \& Mgbame, C.O. (2012). Indirect tax and economic growth, Research Journal of Finance and Accounting, (3) $11,70-82$

IMF, OECD, UN and World Bank (2011). Supporting the development of more effective tax systems. Report to the G-20 Development Working Group

Khumbuzile D. \& Khobai H. (2018). The 
impact of taxation on economic growth in South Africa, MPRA Paper No. 86219, https://mpra.ub.uni-muenchen.de/86219/

Macek, R. (2014). The impact of taxation on economic growth: Case study of OECD Countries. Review of Economic Perspectives - Národohospodářský Obzor, (14), 309-328, Doi: 10.1515/revecp-2015-0002

Kesner - Škreb, M. (1999). Tax policy and economic growth. Economic Trends and Economic Policy (Privredna Kretanja I Ekonomska Politika), 73, 62-121

Mahir Hrnjić1, Azra Branković2 (2017). Endogenous growth model: evidence from East European countries. Economic Review - Journal of Economics and Business, 15, 33-46

Odusola A.F. (2006). Tax policy reforms in Nigeria. UNU World Institute for Development Economics Research (UNU-WIDER). Research Paper No. 2006/03.

Onakoya A.B., \& Fintinni O.I. (2016). Taxation and economic growth in Nigeria. Asian Journal of Economic Modelling, 4(4): 199-210

Owino, O.B. (2019). An empirical analysis of value added tax on economic growth, evidence from Kenya data set. Journal of Economics, Management and Trade 22(3): 1-14

Ola, C. S. (2001). Income tax law and practice in Nigeria,. Heinemann Educational Books (Nigeria) Limited.

Romer, Paul M. (1994). The origins of endogenous growth. Journal of Economic Perspectives- (8)1, 3-22

Stoilova, D. \& Patonov N. (2012). An empirical evidence for the impact of taxation on economy growth in the European Union. Book of Proceedings - Tourism and Management Studies International Conference Algarve,.3, 1031-1039

Todaro, M. \& Smith S. (2012). Economic Development, Eleventh Edition, Pearson Education, Inc., Rights and Contracts Department, 501 Boylston Street, Suite 900, Boston, MA 02116.

Tosun, M.S.\& Abizadeh, S. (2005). Economic growth and tax components: an analysis of tax changes in OECD. Applied Economics, 37, 2251-2263

Umoru, D. \& Anyiwe, M.A. (2013). Tax structures and economic growth in Nigeria: disaggregated empirical evidence. Research Journal of Finance and Accounting 4(2), 65-79

Uzoka, Patrick U., \& Chiedu, Christian, O., (2018). Effect of tax revenue on economic growth in Nigeria. International Journal of Social Sciences and Management Research (4)7, 17-24

Vatavu, S., Lobont, O. R., Stefea, P., \& Brindescu-Olariu, D. (2019). How taxes relate to potential welfare gain and appreciable economic growth. Sustainability, doi:10.3390/su11154094

Van Parys, S., James, S. (2009). Why Tax Incentives may be an Ineffective Tool to Encouraging Investment? - The Role of Investment Climate' (December 1)

Zee, H., J. Stotsky, \& E. Ley (2002). Tax Incentives for Business Investment: A Primer for Policy Makers in Developing Countries. World Development, 30, 1497-1516 


\title{
TOURISM POLICY RESEARCH AFTER THE COVID-19 PANDEMIC: RECONSIDERING THE ROLE OF THE STATE IN TOURISM
}

\author{
James Kennell \\ Department of Marketing, Events and Tourism, University of Greenwich, \\ Old Royal Naval College, Park Row, London, SE10 9LS, United Kingdom. \\ Email:j.s.kennell@greenwich.ac.uk
}

\begin{abstract}
Over the last thirty years of research into tourism policy, there has been a dominant assumption that the appropriate role of the state in tourism is mostly settled. The state has a legitimate role in the tourism industry, but it is essentially one of 'steering and not rowing'. This assumption has developed against the backdrop of the neoliberal shift towards small states, powerful markets and light touch policy interventions in industry. This research note argues that the measures that have been taken by governments around the world in respect of their tourism industries, in response to the COVID-19 pandemic, are sufficiently significant and long-term to warrant a re-appraisal of the role of the state in tourism. Specifically, this note makes the case for a renewed focus on research into tourism policy in non-Western contexts, where the role of the state has not been as constrained by the neoliberal shift, and for an increase in international comparative policy research, which has been notably absent in the tourism policy field to date.
\end{abstract}

Keywords: Tourism policy; COVID-19; neoliberalism; role of the state

Over the last thirty years of research into tourism policy, there has been a dominant assumption that the appropriate role of the state in tourism is mostly settled. The state has a legitimate role in the tourism industry, but it is essentially one of 'steering and not rowing'. In those countries where this was not the case it was because they had extremely radical, or extremely conservative, governments and this would most likely only be a temporary state of affairs. That there has been a 'shift from government to governance' (Bramwell \& Lane, 2011) in the creation and implementation of tourism policy has become almost axiomatic in the literature. Ever more frequently, the solution to problems at every point in the tourism policy cycle has been prescribed to be more governance, and the involvement of an increas- ingly wide range of stakeholders at all stages. Despite ongoing work in the political economy of tourism that has engaged with more broad issues of tourism's place in the global economy (Bianchi, 2018), tourism policy research has mostly made use of functional models of tourism policymaking (Airey, 2015) in which the state curates a largely value-free cycle of policy formulation, implementation and evaluation.

In many ways, it is not surprising that tourism policy research has continued under these assumptions. Research from the core, Western economies has taken place against the backdrop of the neoliberal shift towards small states, powerful markets and light touch policy interventions in industry. In these contexts, it has become dogma for policy makers to 
assert that the private sector knows best how to grow the tourism industry and that the most important role for government is to get out of the way of enterprise and to cut 'red-tape'. The UNWTO and the WTTC, the two most prominent international organisations making the argument for tourism to policymakers and attempting to guide the global growth of tourism from public sector and private sector perspectives, have been instrumental to this. Accelerating this trend, the Global Financial Crisis (GFC) that began in 2007 impacted the public finances to such an extent, that most government tourism policies became further distanced from the intrinsic benefits of tourism and increasingly focused on the 'hyperneoliberal script' (Amore \& Hall, 2017) of restructuring, market-driven agendas, public-private-partnership (Chaperon, 2017) and economic growth as the sine qua non of tourism development. The growing exception to this view over the last decade has been the call, from academics and civil society, for governments to increase regulation in the face of the climate crisis (Gossling et al, 2020). However, ongoing academic arguments over the ideal balance between economic development and sustainability (Higgins-Desbiolles, 2020) mirror the lack of progress on addressing the climate crisis in tourism policymaking.

More recently, a growing body of research into tourism policymaking and evaluation has emerged, where the formulation of policy does not conform to these assumptions about the role of the state and the centrality of governance for successful policy outcomes. Generally, these have been positioned as outside of the mainstream of tourism policy research and have involved the use of non-traditional research inquiries (Hassan et al., 2020) or have particularly unique development contexts (Jenkins, 2015). Broadly speaking, this research has taken place in developing countries, emerging and transition economies, postcolonial settings and, importantly, China. In these destinations, combinations of powerful local states, supranational institutions and quasi-public NGOs continue to take the central role in tourism policymaking. This means that their tourism development is taking place in ways that challenge neoliberal convictions about the role of the state and its relationship to markets, especially outside of the governance frameworks that are seen as essential to good outcomes in the global North. Up to now, this research has helped to illuminate the more hierarchical models of tourism governance (Hall, 2011), or at the very least has blurred the boundaries between these categorizations. Mainstream tourism policy research would suggest little could be learnt from these extreme cases, and that the states they were in would develop incrementally (or through upheaval) in a way that would eventual conform to the hyperneoliberal script that dominates elsewhere. However, various crises and the emergence of alternative development paradigms have called the dominance of neoliberalism into question, and Fukyama's 'end of history' may never have been fully realized. The spread of the COVID-19 pandemic has led to a more widespread interruption of the neoliberal perspective on the appropriate role for the state within tourism, and tourism policy researchers must now respond.

The global COVID-19 pandemic caused by the SARS-CoV-2 virus began in China in 2019 and has progressed to the stage where every region of the world has been affected. This respiratory disease spread quickly through international travel. Tourist facilities that brought together large numbers of people indoors, such as ski resorts and sporting events, have been heavily implicated in its transmission. As governments around the world reacted to the pandemic, tourism became one of the most affected sectors. Between 
January to August 2020, international tourist arrivals fell by $70 \%$, meaning that there were 700 million fewer tourists travelling, leading to a global loss of US $\$$ 730 billion in revenues, more than eight times the amount lost as a result of the GFC (UNWTO, 2020).

The impact of COVID-19 on the tourism industry has been momentous. Major restrictions have been placed on the freedoms of individuals and firms in many destinations, and with rolling temporary lockdowns this has created a hugely challenging and uncertain operating environment for the industry. During this period, many governments have significantly increased their border controls with many important tourism economies, such as Australia and Thailand, imposing temporary bans on both inbound and outbound travel. At the start of the pandemic, many National Tourism Offices (NTO) and Destination Management Organisations (DMO) attempted to pivot their strategies towards increasing the volume and value of domestic tourism, with the hope that this would help to mitigate the worst impacts of these bans. Unfortunately, the nature of the domestic travel restrictions that often followed forced the closures of venues, hotels, restaurants and attractions, and this has meant increasing domestic tourism has only been viable in destinations with very low levels of local infection, such as Japan. In the United Kingdom, which has been badly affected by the virus, domestic tourism is projected to fall by $45-50 \%$ in 2020 (OECD, 2020).

Even in the neoliberal economies of the Global North, the state has now taken on a hugely interventionist role in the tourism industry, and this is likely to last for some time. Previous crises affecting tourism such as those prompted by the terrorist attacks in New York in 2001, or by the GFC, have been limited in their duration, with international tourist arrivals rebounding relatively quickly along with consumer confidence. In these cases, the most common activities for states in the main tourism economies was to continue to act through their intermediary agencies, usually their NTOs and DMOs, to support new marketing campaigns. Additional security and border controls after 2001 added inconvenience to international travel, but did not prevent it, and had very little impact on the industry beyond key transit points. Crucially, the impact of these crises was short-term and did not lead to long-terms reconfigurations of the relationship between the state and the tourism industry. The effects of the COVID-19 pandemic on consumer confidence, the devastating impact on individual tourism businesses, widespread job losses, and the industrial restructuring that is likely to follow in the wake of the pandemic mean that the impacts of the crisis will be more enduring, with predictions that international tourism arrivals could take up to five years to recover.

Across the world, the state is now the most important actor in tourism policymaking, exercising its power to open and close borders and to open and close businesses, in a way that was previously only expected of authoritarian regimes. A period of retrenchment from investment in tourism in many countries in the wake of the GFC is being replaced by enormous state intervention in the form of direct funding for the sector. In many countries, the state is paying the wages of tourism and hospitality workers who would otherwise become unemployed, and is subsidizing businesses to prevent them from failing. The very real threat of a destination losing its capacity to meet the demand for future international tourism has sharpened the thinking of policymakers about the contribution of tourism to their economies. It is no longer possible for governments to take tourism for granted and state support for the post-COVID recovery will need to be 
massive and sustained over the long term. This will have huge implications for the relationship between the state and the private sector in tourism, as the restructuring of the industry after the pandemic will be accompanied by innovations in industrial policy at the government level.

To fully understand these transformations, it will be necessary for tourism policy researchers to approach them from new perspectives. The previously dominant assumption that a hallmark of a successful tourism destination would be a small, enabling state presence in the industry, and the participation of a wide range of stakeholders in its governance, will need to be re-examined in order to make sense of the 'new normal' for tourism policy. To do this, it will be necessary to look for examples of successful state intervention in tourism. Recent tourism policy research from outside of the core neoliberal economies will be vital in this effort. Case studies abound of tourism policy interventions in non-Western and developing country contexts, and these previously marginal or extreme cases can now become more central in helping us to understand the contemporary role of the state in tourism. Much of this research has previously been seen as highlighting the relationship between tourism and development, but its implications for tourism governance and policy should now be much more clear. For example, the ways in which the Chinese government has intervened to support domestic tourism, creating public holidays and directly subsidizing tourism development away from the prosperous Eastern coast of the country were considered almost heretical from within the neoliberal tourism development script of the West. Now, however, evaluating interventions like these and learning from them should be a priority for tourism policy research that aims to have real-world impact.
As state intervention in tourism increases globally, the political character of the state will become more influential in shaping the tourism industry of a destination. Ideological differences between governments will have more noticeable implications for tourism development as decisions are made about what and who to support, and what the conditions and expectations are for this. With greater international diversity in support for tourism, more comparative research will become possible, and necessary, meaning that tourism policy analysis should come to draw more heavily on theories and tools from the public policy literature and especially that dealing with international comparative policy analysis, which has been noticeably absent in tourism policy research to date. Following the COVID-19 pandemic, tourism policy research will need to reengage with debates about the role of the state in the tourism industry, and the role of tourism within the state.

\section{References}

Airey, D. W. (2015). Developments in Understanding Tourism Policy. Tourism Review, 70(4), 246-258.

Amore, A., \& Hall, C. M. (2017). National and urban public policy in tourism. Towards the emergence of a hyperneoliberal script?. International Journal of Tourism Policy, 7(1), 4-22.

Bianchi, R. (2018). The political economy of tourism development: A critical review. Annals of Tourism Research, 70, 88-102.

Chaperon, S. (2017). Tourism industry responses to public-private partnership arrangements for destination management organisations in small island economies: A case study of Jersey, Channel Islands. International Journal of Tourism Policy, 7(1), 23-41.

Gössling, S., Scott, D., \& Hall, C. M. 
(2020). Pandemics, tourism and global change: a rapid assessment of COVID-19. Journal of Sustainable Tourism. https://doi.org/10.1080/09669582.2020.1758708

Hall, C. M. (2011). A typology of governance and its implications for tourism policy analysis. Journal of sustainable tourism, 19(4-5), 437-457.

Hassan, A., Kennell, J., \& Chaperon, S. (2020). Rhetoric and reality in Bangladesh: elite stakeholder perceptions of the implementation of tourism policy. Tourism Recreation Research, 45 (3): 307-322

Higgins-Desbiolles, F. (2020). The "war over tourism": challenges to sustainable tourism in the tourism academy after COVID-19. Journal of Sustainable Tourism. https://doi.org/10.1080/09669582.2020.1803334

Jenkins, C. L. (2015). Tourism policy and planning for developing countries: Some critical issues. Tourism Recreation Research, 40(2), 144-156.

OECD (2020) Rebuilding Tourism for the Future: COVID-19 Policy Response and Recovery. Paris. OECD.

UNWTO (2020) Impact Assessment of the COVID-19 Outbreak on International Tourism [online]

Available from: https://www.unwto.org/impact-assessment-of-the-covid-19-outbreak-on-international-tourism Accessed 29th November 2020 


\title{
ETHNIC CONFLICTS AND GEOPOLITICS: COVID-19 AUGMENTED CHAOS VERSUS EFFORTS TO RESTART TOURISM SECTOR
}

\author{
S.C. Bagri \\ Professor, Centre for Mountain Tourism and Hospitality Studies, \\ HNB Garhwal University ( a central University). Srinagar, Uttarakhand, India \\ Email:prof.bagri@gmail.com \\ Junaid K.C. \\ Research Scholar, \\ Centre for Mountain Tourism and Hospitality Studies, \\ HNB Garhwal University ( a central University). Srinagar, Uttarakhand, India \\ Email:junaidkc@gmail.com
}

\begin{abstract}
By 2019, the Travel and Tourism sector was growing sustainably while compared to any other industry in the world. With a contribution of US\$8.9 trillion to the world's GDP (10.3\% of global GDP), and accounted for around 330 million jobs (1 in 10) worldwide (Neufeld, 2020: WTTC, 2020a). But, the outbreak of COVID-19 in December 2019 dramatically changed the entire scenario worldwide. As of now, the global pandemic effects will take the travel and tourism sector back to 20 years (Richter, 2020). Reports of UNWTO and WTTC forecasted 121 million direct tourism jobs in risk and a decline of around 80\% in international tourist arrivals in the year 2020 (UNWTO, 2020a; WTTC, 2020b). Many studies have discussed that the COVID-19 lead worldwide travel restrictions, international sanctions and economic crisis, boosted ethnic conflicts and geopolitical tensions at local and international level. This article elaborates on trends of the global travel and tourism sector before and since the COVID-19 pandemic concerning the ethnic conflicts and geopolitics happening around the world. The present research article is based on the reports of UNWTO, WTTC and other national bodies besides the scholarly writings contributed by Burke, Chetcuti et al., Polo, Seyfi et al., Wilkinson et al., Jawabreh, Mostafanezhad, Timothy and Rowen. Authors have also attempted to review the news and views that appeared in the print and electronic medias. And whatever the issues and trends were noticed have been elaborated in the present research paper supported by statements on recent measures by government or non-government agencies to restart the tourism sector.
\end{abstract}

Keywords: Geopolitics, ethnic conflicts, COVID-19, rethink tourism

\section{The Boom and Bust.}

According to the World Bank (2020) report, during 2019 alone, the service sector has contributed about 61.2 per cent to the global GDP. Correspondingly, in the same year, Travel \& Tourism sector's direct, indirect and induced share on global GDP is around $10.3 \%$ with a growth per cent of $3.5 \%$, and a total of US\$ 1.7 trillion visitor exports included of $6.8 \%$ of total exports, $28.3 \%$ of global services exports (WTTC, 2020a). Counties like the US (1.8 trillion), China (1.58 trillion), Japan, Germany, Italy, UK, France, Spain, Mexico, and India ranked top in terms of the T\&T sector's contribution to GDP (Neufeld, 2020). Moreover, this sector ensures around 330 million jobs, consists of 1 in 10 jobs around the world, with more opportunities for women, youth, minorities and indigenous 
communities (WTTC, 2020a; 2020c). Things changed dramatically by December 2019 with an uncontrolled spread of COVID-19 reported in Wuhan, China (Liu, 2020). By March 2020 WHO declared the COVID-19 (novel coronavirus) as a global pandemic (WTTC, 2020c). And of course, it created a lot of chaos in every sector including the $\mathrm{T} \& \mathrm{~T}$, most compelling evidence by WTTC (2020c) gives that in March 2020, 39\% of countries have closed their borders for non-citizens and non-residents. As the COVID-19 infection rate kept doubled around the world by April 2020, 100\% of tourism destinations were compelled to introduce travel restrictions and new emergency sanctions to control the spread of the virus (UNWTO, 2020a). Complete or partial border closure to tourist, destination-specific travel restrictions, suspension of flights, visa bans, domestic or local travel bans, quarantine rules and special medical requirements made humans immobile (UNWTO, 2020c). More specifically travel restrictions have been imposed in 100\% of African, Asian and the Pacific and the Middle East destinations, 93\% of European and $92 \%$ of American tourist destinations (UNWTO, 2020c). In the early stage itself, the reports of UNWTO (2020a), OECD (2020), and WTTC (2020c) forecasted that international tourist arrivals could drop by around $80 \%$ in 2020. which further reflected in the $T \& T$ sector with zero demand, mass revenue decline, high costs, furloughs, job loss, and bankruptcy (WTTC, 2020c). These circumstances made a forecast of 121 million jobs loss and a loss of $\$ 3.4$ trillion in global GDP by the T\&T sector alone (UNWTO, 2020a; WTTC, 2020b; 2020c). Richter (2020) from the World Economic Forum quoted that "COVID-19 could set the global tourism industry back 20 years". The International Labour Organization (ILO, 2020) expressed thatthree in four workers of the tourism sector in Asia and Pacific countries are engaged in informal jobs. which don't guarantee any job security or they are more vulnerable to the negative impacts of the COVID-19 lead crisis happening now.

\section{Contemporary Issues and Geopoliti- cal Tensions}

Just like all the other crises, this current pandemic has impacted negatively on the economy, society, and environment. Over and above valuing the monetary losses, efforts are to made to dive deep into tangible and intangible social impacts happening in the communities too. Many researchers have reported different field shreds of evidence of sudden growth in conflicts and geopolitical tensions around the world since the COVID-19 outbreak (Burke; Chetcuti et al.; Polo; Seyfi et al.; Wilkinson et al., 2020). The sources of these ethnic conflicts can be political, social, economic and religious, which is already deeply rooted before and further boosted during COVID-19 (Burke, 2020; "Ethnic conflict", n.d.). Doesn't matter it is Rohingya genocide, Kurdish-Turkish conflict, Sri Lankan Civil War or Communal conflicts in Nigeria, all of these had negatively impacted the growth and image of the local tourism projects or any related international destinations in one or another form ("Ethnic conflict", n.d.). Even before the current global pandemic, many western countries have imposed restrictions on travelling to and from a few Middle East countries by considering the risk of social or ethnic conflicts (Jawabreh, 2020). Not only the civil wars of Iraq, Lebanon, and Syria affected tourism growth in the Middle East, but also it is affected by how the foreign media framed the region negatively by reporting only wars and conflicts (Butler, 2019; Jawabreh, 2020). It is indeed that even a piece of single fake news on disputes will create a negative image for any tourist destination forever. On top of ongoing ethnic conflicts around the world, COVID-19 have made new grounds for food scarcity, broken healthcare system and administration, gender and race discriminations, domestic 
violence and mass unemployment (Burke; Bentley; Chetcuti et al., 2020). Few examples underlined by Burke (2020) are 1) how few extremist groups in the Middle East are using the pandemic crisis to spread the propaganda and promote new recruitments. 2) how Bangladesh and Malaysia rejected recent Rohingyan boats amid the fear of COVID-19 spread and resulted as the death of many migrants in the sea. 3) How India's online and physical attack on minorities by claiming a particular community as the only reason for the super spread. Polo (2020) stated that the world becomes more socially unrest, violent and less democratic than what was before the detection of global pandemic (COVID-19). The case is even worse for many countries where the existing conflicts have already made the citizens not to trust authorities, and fewer options to implement any centralized command or control approach to reduce pandemic spread (Wilkinson et al., 2020).

In the same fashion, new geopolitical tensions have developed as countries announced emergency border closures, travel restrictions or bans, international sanctions, strict visa regulations, lockdowns, quarantine rules and other measures for the sake of controlling pandemic spread (EU Parliament; Seyfi et al., 2020). Even before the global pandemic, geopolitics have negatively impacted the growth of numerous tourism destinations, it was mostly by the geopolitical tensions between countries in the West, Middle East, and Asia (Bremmer, 2020; Butler, 2019; Rowen, 2016; Timothy, 2019). Conflicts on the South China Sea between China, Philippines and Vietnam, land disputes between China and India for Kashmir/Ladakh are a few examples of local geopolitics in Asia (Timothy, 2019). Report by TIME (Bremmer, 2020) states that both the US and China are using economic tools like international sanctions, export control and boycotts to acquire more geopolitical power. At the same time, China's political decisions like the Passport War of 2012 on Hong Kong and Taiwan had negatively impacted the peaceful grounds of tourism activities within the region (Rowen, 2016). Besides, the role played by the tourism sector for implementing the state's geopolitical programs of Chinese authorities and how tourism has been used as a tool for crafting foreign policies and territorial projects are also issues affecting the industry. In the same manner, US's tourism is being affected by its restrictions on citizens' visit to countries like Cuba, Iran, Iraq, Libya, Somalia, Sudan, Syria, and Yemen (Seyfi et al., 2020). To an extent, the current geopolitical anxieties on tourism are affected by primaeval race geographies and recent developments of geo-economic relations (Mostafanezhad et al., 2020). Belt and Road or One Belt One Road is a global infrastructure development initiative of China, which promises a new platform for extending their geo-economic relations to become a global power (EU Parliament, 2020). In respect of the recent COVID-19 lead global economic crisis, more geopolitical tensions have emerged between global powers, nations or regions (EU Parliament; Mostafanezhad et al.; Seyfi et al., 2020). Many countries have adopted Travel Bubble initiatives to reopen the borders and resume controlled travels between predetermined countries or regions. According to the report of Wego (2020), as of May 2019 itself, China and South Korea lifted travel restrictions by linking them. By the end of October 2020, the EU has relaxed travel restrictions with Australia, Japan, New Zealand, Rwanda, Singapore, South Korea, Thailand and Uruguay. Similarly, India has initiated new bilateral travel arrangements with more than 21 countries. Nevertheless, there exist uneven political geography of sanctions and policies to achieve political goals (Seyfi et al., 2020). 


\section{Rethink and Restart the Tourism}

Although the COVID-19 has created immense chaos in the tourism sector, gradually it became a platform to rethink and restart the tourism sector. Worldwide travel bans and freezing of tourism activities stricken governments, trade organizations, industry experts, entrepreneurs, policymakers, tourism researchers and other stakeholders to rethink travel activities and interaction with nature, climate and economy. As recovery measures from a pandemic crisis, the sector needs to focus on the sustainable and responsible model of travel experiences that ensures the safety of host communities, travelers and other direct stakeholders. As part of recovery plans, the investment packages must follow models that promote economic empowerment of local communities, decent income and benefit distributions, more carbon-neutral practices and inclusive developments. UNWTO (2020d) recommends drafting recovery policies which create decent job opportunities for youth, women and vulnerable communities. It also highlighted five points of the road map to transform tourism during and post COVID-19 lead crisis. The first and foremost is to build confidence by strengthening partnerships and solidarity between destinations and stakeholders with an inclusive approach of protecting livelihoods. The second one is to facilitate a better business environment and investment opportunities for local travel SMEs, domestic tourism destinations and niche tourism markets. Applications of advance innovation, digitalization of the tourism ecosystem, and enrichment of the tourism workforce by updated digital skills come as the third point of road map to transform tourism. The next two points are on fostering sustainability and green growth in addition to coordination and partnerships to achieve the Sustainable Development Goals. It also includes people-oriented policy making beside the involvement of government, development partners and other international financial institutions. Some of the best recovery models that have already been adopted around the world to restart the tourism industry include

a) Egypt's postponement of tourism stakeholder's dues.

b) Bulgarian government initiatives for covering the insurance payments owed by the tourism employers. c) suspension of tax payments for travel business in Italy. According to WTTC (2020c), 80\% of the tourism sector is an account for Small and Medium-Sized Enterprises (SMEs). And they are intensively affected by the global pandemic. Netherland's Corona Bridging Loan and Portugal's Mezzanine are some of the unique government initiatives for boosting travel startups/SMEs to survive and recover from the hard-hit of the global pandemic lead crisis. Bangladesh's Committee for Crisis Management and Malaysia's Tourism Recovery Action Council (TRAC) is working on tackling problems and designing recovery plans within various areas of the tourism sector. The best part of these initiatives is that it has created a new platform to rethink existing tourism models and recommend new models to fasten the recovery process sustainably. Other promising initiatives are ICAO's Council Aviation Recovery Task Force (CART), UNWTO's Global Tourism Crisis Committee. Besides its representatives of stakeholders from government agencies and private sector, alongside WHO, ICAO, ILO, IMO, WBG, OECD, ACI, CLIA, IATA and WTTC are helping to rethink and restart tourism activities around the world. UNWTO International Network of Sustainable Tourism Observatories and One Planet Network Sustainable Tourism Programme further ensures the tourism sector to achieve SDGs in the process of the post-COVID-19 recovery. WTTCs initiatives to restart travel sector includes 'Safe Travels Protocols and Stamp', 'Together in Travel' social media 
campaign (\#TogetherInTravel), '100 million jobs' with G20 nations and constant industry update meetings with Airports Council International (ACI), Cruise Lines International Association(CLIA), Duty-Free World Council (DFWC), International Air Transport Association (IATA), Organization for Economic Co-operation and Development (OECD), Pacific Asia Travel Association (PATA), United Nations World Tourism Organization (UNWTO), U.S. Travel Association (USTA) and World Economic Forum (WEF).

Rapid progress has seen the transformation of the tourism sector to use technological innovations like biometric initiatives which ensure seamless, safe and hygiene journey experience to everyone. According to WTTC (2020a), the use of biometric technology will reduce boarding time by $66 \%$ from 45 minutes to 15 minutes. As the global pandemic demands more touch-free travel experiences and social distance options, the policymakers and travelers are adopting the use of biometric technologies for travel booking, documentation, security clearance, boarding and more. Henceforth, the tourism sector won't get any better opportunity than the current pandemic crisis to upgrade airports, public transportations, destination centres, front offices, checking points, verification and payment systems etc. with international standard biometric solutions. Even though digitalization has existed in the tourism sector for many years, Post COVID-19 is forecasted as an era of digital boom. The rise of virtual tourism and contactless travel experiences remains the most happening trends. Additionally, these trends are demanding new skills in tourism and hospitality workers. To achieve digital skills, one has to eliminate the digital divide in many developing and least developed countries. An early 2011 study by Amadeus (2011) on the travel trend of 2020 has highlighted the consumer trends towards tourism products of health and wellbeing. And the same trends have multiplied many times because of the global pandemic hit. COVID-19 has also made more tourists plan trips accordingly by including activities of health and wellbeing. Now the tourists are rethinking themselves to choose wellness tourism and health tourism destinations instead of mass tourism destinations. The governments, tourism departments, trade organizations, local communities and other primary stakeholders have started to create participative policies to boost wellness and health tourism to ensure the fast recovery of the tourism sector. Another important aspect is that the tourism sector plays a significant role in connecting counties and communities together for peace and mutual prosperity. The more people travel and interact with other people, the more they understand and accept each other which further helps to reduce the gap created by prejudice, tensions, and conflicts (Sonmez and Apostolopoulos, 2000). Restarting tourism with more confidence and cooperation will decrease the chaos that existed before the global pandemic and augmented during the crisis. Not to mention that more oil nations have started to invest in the service industry like tourism as a future economic source compared to earlier traditional fossil fuel industries (Becken and Friedl, 2018). The same will bring a positive outlook towards the environment and a new boom of cultural exchange in the Middle East region with the help of the tourism sector. Before the pandemic, in 2019 countries like United Arabs Emirates, Qatar and Saudi Arabia have shown a good competitiveness power in the tourism sector compared to any other Middle East countries (Nazmfar et al., 2019). Recent policies introduced by the UAE to boost relationships and connect more destinations are giving a new ray of 
hope for world peace and prosperity.

\section{Looking Ahead}

Ethnic conflict and geopolitics have affected the tourism sector even before and during the COVID-19 lead crisis, and the same trend will continue in one or another way for many tourism destinations. To put it another way, tourism has to be used as a tool to create world peace, better social inclusion and to reduce the negative impacts of ethnic conflict and geopolitical tensions. Despite all chaos made by the global pandemic crisis, the tourism sector will recover to its boom stage again. The essence of the restarting activities must be surrounded by environmental responsibility, technological advancements in business and consumer needs. As mentioned earlier the tourism sector won't get any better chance than the global pandemic to rethink their products and services. The tourism sector has to rethink and redesign activities according to the next trends of 'tech-savvy travelers and experiential holidays. Hotels and restaurants have to digitize every single process to reduce the cost, to create a new experience and to ensure safety, security and hygiene. Using cloud technology in property management systems hotels can ensure better performance with less cost. Likewise, SMEs can improve brand image by utilizing user-generated contents and peer to peer platform celebrities to attract their niche market. The study observes a high demand for wellness, health, sports, extreme and other experiential tourism products. Experiential holidays demand every activity from planning to post-tour reviews as designed as more experienceable. The new consumers are demanding smart pay systems, non-contact services, and smartphone-controlled room facilities along with high-end activity-based trips. Thus, it is essential to combine both aspects of tech and experience while designing any components of a tour program. It is difficult to arrive at any specific conclusions about post-COVID-19 trends in the tourism sector. But, surely, most of the travel trends will emerge either due to the digital boom or the desire for experiential travel.

\section{References:}

Amadeus (2011). Future Traveller Tribes 2020. Amadeus.com. Retrieved from: https://amadeus.com/en/insights/res e a r c h - re p ort/future - travel ler-tribes-2020 Accessed on 1st November 2020.

Becken, S., \& Friedl, H. A. (2018). Oil in the Middle East, A critical resource for tourism. Routledge Handbook on Tourism in the Middle East and North Africa.

Bentley, G. R. (2020). Don't blame the BAME: Ethnic and structural inequalities in susceptibilities to COVID-19. American Journal of Human Biology, 32(5), e23478.

Bremmer, I. (2020, January 6). The Top 10 Geopolitical Risks for the World in 2020. Time. Retrieved from: https://time.com/5758978/world-risks-2020/

Accessed on 10th November 2020.

Ethnic Conflicts in the Wake of Covid-19. Retrieved from: https://www.ispionline.it/en/pubblicazione/asias-ethnic-conflicts-wake-covid-19-26355, Accessed on Accessed on 16/11/2020.

Butler, R. W. (2019). Tourism and conflict in the Middle East. Routledge handbook of tourism in the Middle East and North Africa, 231-240.

Chetcuti, P., Pelham, S., Truscott, M., \& Smyth, F. (2020). Conflict in the Time of Coronavirus: Why a global ceasefire could offer a window of opportunity for inclusive, locally-led peace. Oxfam DOI: $10.21201 / 2020.6058$ 
Ethnic conflict. (n.d.), In Wikipedia. https://en.wikipedia.org/wiki/Ethnic_conflict Accessed on 11th November 2020.

EU Parliament. (2020, October 20). The geopolitical implications of the COVID-19 pandemic. European Parliament. European Parliament. Retrieved from: https://www.europarl.europa.eu/com mit tees/en/the-geopolitical-implications-ofthe-cov/product-details/20201016CAN57986 Accessed on 2nd November 2020.

ILO (2020). COVID-19 and employment in the tourism sector: impact and response in Asia and the Pacific. International Labour Organization. Retrieved from: https://labordoc.ilo.org/permali n k / 41 I L O_ I N S T/ j 3 q 9 o n / a l ma995083193202676, Accessed on 11th November 2020.

Jawabreh, O. (2020). Management of Tourism Crisis in the Middle East. In Public-sector Crisis Management. IntechOpen. DOI: 10.5772/intechopen. 90174

Liu, R., Han, H., Liu, F., Lv, Z., Wu, K., Liu, Y., \& Zhu, C. (2020). Positive rate of RT-PCR detection of SARS-CoV-2 infection in 4880 cases from one hospital in Wuhan, China, from Jan to Feb 2020. Clinica Chimica Acta. Pages 172-175, ISSN 0009-8981, https://doi.org/10.1016/j.cca.2020.03.009.

Mostafanezhad, M., Cheer, J. M., \& Sin, H. L. (2020). Geopolitical anxieties of tourism: (Im) mobilities of the COVID-19 pandemic. Dialogues in Human Geography, 10(2), 182-186.

Nazmfar, H., Eshghei, A., Alavi, S., \& Pourmoradian, S. (2019). Analysis of travel and tourism competitiveness index in middle-east countries. Asia Pacific Journal of Tourism Research, 24(6), 501-513
Neufeld, Dorothy (2020), Visualizing the Countries Most Reliant on Tourism, Visual Capitalist (May 22, 2020). Retrieved from: https://www.visualcapitalist.com/countries-reliant-tourism Accessed on 10/11/2020.

OECD (2020, October 22). Rebuilding tourism for the future: COVID-19 policy responses and recovery. OECD. Retrieved from: http://www.oecd.org/coronavirus/policy-responses/rebuilding-tourismfor-the-future-covid-19-policy-responses-and-recovery-bced9859/, Accessed on 10th November 2020.

Polo, S. M. (2020). A Pandemic of Violence? The Impact of COVID-19 on Conflict. Peace Economics, Peace Science and Public Policy, 26(3).

Richter, Felix (2020), COVID-19 could set the global tourism industry back 20 years, We Forum (02 Sep 2020). Retrieved from: https://www.weforum.org/agenda/ 2020/09/pandemic-covid19-tourism-sector-tourism/, Accessed on 16/11/2020.

Rowen, I. (2016). The geopolitics of tourism: Mobilities, territory, and protest in China, Taiwan, and Hong Kong. Annals of the American Association of Geographers, 106(2), 385-393.

Seyfi, S., Hall, C. M., \& Shabani, B. (2020). COVID-19 and international travel restrictions: the geopolitics of health and tourism. Tourism Geographies, 1-17.

Sonmez, S. F., \& Apostol Poulos, Y. (2000). Conflict resolution through tourism cooperation? The case of the partitioned island-state of Cyprus. Journal of Travel \& Tourism Marketing, $9(3), 35-48$.

Timothy, D. J. (2019). Tourism, border disputes and claims to territorial sover- 
eignty. Tourism and hospitality in conflict-ridden destinations, 25-38.

UNWTO (2020b), International Tourism and Covid-19, UNWTO tourism Dashboard, 2020. Retrieved from: https://www. unwto.org/international-tourism-and-covid-19 Accessed on 10/11/2020.

UNWTO (2020a), Impact Assessment of the Covid-19 Outbreak on International Tourism. (Published on May 2020). Retrievedfrom:https://www.unwto.org/impact-assessment-of-the-covid-19-outbreak-on-international-tourism, Accessed on $10 / 11 / 2020$.

UNWTO (2020c). COVID-19 Related Travel Restrictions. UNWTO. Retrieved from: https://www.unwto.org/covid-19-

travel-restrictions, Accessed on 5th November 2020.

UNWTO (2020d, August). UNSDG. Policy Brief: COVID-19 and Transforming Tourism. Retrieved from: https://unsdg.un. org/resources/policy-brief-covid-19-and-transforming-tourism Accessed on 5th November 2020.

Wego (2020, November 10). What is a Travel Bubble? Here's Everything You Need to Know About the Buzzy New Term. Wego Travel. Retrieved from: https://blog.wego.com/whats-a-travel-bubble/, Accessed on 13th November 2020.

Wilkinson, A., Ripoll, S., Schmidt-Sane, M., \& McLeod, K. (2020). Key Considerations: COVID-19 in the Context of Conflict and Displacement-Myanmar.

World Bank (2020, November 14). Services, value added (\% of GDP). World Bank Open Data, Retrieved from: https://data.worldbank. org/indicator/NV.SRV.TOTL.ZS , Accessed on 14/11/2020.
WTTC (2020a), Travel \& Tourism Global Economic Impact \& Trends, London, UK. Published on June 2020. Retrieved from: https://wttc.org/Research/Economic-Impact, Accessed on 16/11/2020.

Travel and Tourism Council. Retrieved from: https://wttc.org/COVID-19 Accessed on $10 / 11 / 2020$.

WTTC (2020c). To recovery \& beyond, Future of travel \& tourism. World travel \& tourism council (WTTC). Retrieved from https://wttc.org/Research/To-Recovery-Beyond, Accessed on 10/11/2020. 


\title{
DYNAMICS IN ACADEMICS AND CONSUMER RESEARCH IN POST-COVID-19 SCENARIO
}

\author{
Tejinder Sharma \\ Department of Commerce \\ Kurukshetra University, Kurukshetra, India \\ Email: tsharma@kuk.ac.in
}

\begin{abstract}
COVID-19 pandemic is one of the most unprecedented event in the human history as its impact is truly global, impacting each and every facet of human existence. In this turbulent scenario, education has witnessed a major disruption throughout the world. Online teaching has been construed as switching over to the online platforms to deliver the lectures, which is a good stop-gap arrangement. If it has to be ingrained into the system, then it has to be blended with the operations. Academic leadership catering to vast majority of the resource deficit population needs to take measures to bridge the digital and knowledge divide and the real change will come with bottom-up empowerment.
\end{abstract}

On the consumption front, there is a notable change in the consumers' purchasing behaviour and some of this change is likely to be permanent. the economic uncertainty and instability has fostered transformation in consumer behaviour and there is sustained focus on value and frugality. Crisis has also generated interest into spiritualism and the consumers are revisiting the traditional wisdom, which might influence their thinking and behaviour in the days to come. Consumer research shows that about two-third of the consumers may shift back to normal purchase soon after the pandemic while a few others who have experienced loss of employment of reduction of their incomes will economize on their purchasing. Marketers need to account for this shift in their strategy and need to develop the products and their marketing campaigns to accommodate these trends.

Keywords: Online Teaching, Consumer research, frugality, value buying,

bottom-up empowerment

\section{Background}

COVID-19 pandemic is one of the most unprecedented event in the human history as its impact is truly global, impacting each and every facet of human existence. Commencing as a health pandemic, this has had an impact at macro as well as micro levels. Right from impacting the economy and earnings of the nations and individuals, political issues within the nations and between the nations, inter-personal relations within the societies, the new normal is making its existence felt and probably it will take decades before a new stability may be achieved. There have been pandemics, economic slowdowns and wars between nations, but this scenario is different because the magnanimity of the pandemic induced impacts and the disruption of the value chains are the key differentiators. The world never came to a standstill of this nature for so long and it is because of this disruption that the fulcrum of delicate balance between the subcomponents of the socio-economic systems is undergoing a key change.

In this turbulent scenario, education has witnessed a major disruption throughout the world. Classrooms are seen as the boiling pots for fomenting the pandemic and their physical closure is taken as a 
viable step to containing the pandemic. Surprisingly, most of the other avenues such as the markets, gymnasiums, political activities, gatherings, etc. with larger potential of spreading the pandemic have slowly gathered momentum towards normalcy, but the education institutions remain devoid of students. Despite having technology as a major savior to reach out to the students, online teaching is far from being a substitute for offline teaching. Education is not just dissemination of information from the sender to the receiver, but is a tool for shaping the individuals, carving them to be true professionals and useful members of the society. The very act of attending a class and learning from the teacher shaped the personality of the students, but that new normal is still away.

If the colleges and universities are opened without checks and balances, they bear the risk of launching an exponential spread of the infection as the youth may not maintain social distance. The facilities such as classrooms, hostels and food may not be sterile enough to check the spread of infection. Other sectors faced similar risks, but the phased unlocking can be extrapolated to the higher education as well. There are several options that can be exercised and stepwise measures can help in resuming their functioning within the new normal. More than the pandemic, it's the mindset that has disrupted the education. Academic leadership needs out of the box solutions to restore the normalcy and newer methods of student engagement and evaluation have to be thought of. The knowledge divide is far greater than the digital divide. Its two batches of students who have suffered the most. The cause of the problem is that it's a top-down approach and not a bottom-up decentralized strategy, which can be far more fruitful. Online teaching has been construed as switching over to the online platforms to deliver the lectures, which is a good stop-gap arrangement. If it has to be ingrained into the system, then it has to be blended with the operations.

\section{Scenario Analysis for online teach- ing}

In the present times, three scenarios of the growth and control of the pandemic, and its impact on the online teaching can be predicted. In the first scenario, which is optimistic, it is assumed that the pandemic will be contained in short run as the news of the vaccine will be available in the market and we will be able to resume the normal offline teaching. In such a case, the online teaching can be a good supplement to the classroom interactions. In India, even the use of ICT based gadgets and tools was facing slow adaptation, but the pandemic has broken that mindset and the teachers and students have familiarized themselves to this newer platform for dissemination of teaching.

In the realistic scenario, it is predicted that the pandemic will subside, but not to the extent that normal classroom teaching can begin, at least for coming two sessions as it is difficult to vaccinate billions of people within a few months. There will be uncertainties and disruptions and in such a case, a blend of online and offline interactions is predicted. There is a need for out-of-box thinking to slowly bring the students back to the campuses for enrichment of their online teaching experience. By moderating the flow of students, the norms of pandemic control can be implemented and slowly the momentum can be picked up.

The third scenario is pessimistic, in which we do not expect the things to get better and we have to rely on the herd immunity to overcome the pandemic. In such a scenario, the resumption of normal classroom teaching is less likely and our systems have to gear up to having more of online teaching and evaluation. Academic leadership catering to vast majority of the resource deficit 
population needs to take measures to bridge the digital and knowledge divide. Real change will come with bottom-up empowerment. Teacher in class has to make use of the online platforms for extended learning, beyond the confines of the classrooms. Teaching is a highly scientific process and a judicious mix of the online and classroom interactions has to be developed. Merely making the digital content is not the end of the story. Teachers have to do the handholding of the students and explain the concepts in online/offline interactions. Online platforms have the added advantage of flexi-learning, interactivity and handling of doubts and teachers have to be trained to achieve this purpose. The limitations of infrastructure and connectivity are not big enough in the present times, which cannot be overcome.

\section{Business and consumer research in pandemic regime}

A seminal research has been done by Verma and Gustafsson (2020) analysed 107 research papers published in Scopus and Web of Science indexed journals during the period January to May 2020 using bibliometric study of COVID-19 research in business and management domain. The analysis of the published literature identified four main research themes and 18 sub-themes. The findings and propositions of this study suggest that COVID-19 will be the catalyst of several long- and short-term policy changes and requires the theoretical and empirical attention of researchers. The subthemes underlying the overall impact of COVID-19 on business and management entail decision making, risk management, supply chain dynamics, human behaviour, etc. Researchers have also focused on studying the impact on value chains, start-ups, trade, employment and risk. Technology being a major enabler during the supply chain disruption has generated lot of interest of the researchers. Similarly, the research on service industry, including travel and tourism, online education and essential services has been interest for the researchers. The study envisages further research in these broad domains.

Mehta, Saxena and Purohit (2020) observe that the economic uncertainty and instability has fostered transformation in consumer behaviour and there is sustained focus on value and frugality. Crisis has also generated interest into spiritualism and the consumers are revisiting the traditional wisdom, which might influence their thinking and behaviour in the days to come. A study by Accenture reinforce the belief that some of the changes in consumer behaviour will be permanent and will transform the industry's future. The study found that the consumer purchases centred on basic needs and people were shopping consciously. Digital connect is being increasingly relied upon for managing isolation and building virtual workforces. A study of Fahmy and Sohani (2020) observe that there is not a major shift in the preferred brands during the pandemic, although there is increase in health consciousness and qualitative demands on brands due to pandemic affecting brand preference. Lee (2020) observes thirteen ways that consumer behaviour is evolving in the post pandemic scenario. There is lesser enthusiasm for in-store visits and even the extravagant consumers are concerned about their shopping spree. With shifting workplace to home, there is a marked shift in the buying habits. Consumers have flexible time management and increased demand for remote work product and technologies. Contactless payments, virtual interactions, hunting for value and economizing the purchases, increasing acceptability of digital platforms is a major development and marketers are learning to incorporate them into their marketing strategy. Lee observes the emergence of social good, which is gaining the importance in the minds of the consumers. These trends are going to influence the spending and buying habits of the consumers. 
Schachinger (2020) observes that while e-commerce, online purchase, media consumption, connecting to family and concentrating on personal finances are some of the most interesting developments after the pandemic. The top three bills of most concern for the consumers in the days to come are the utility bills, credit cards, and rent followed by auto loans, mortgage payments, and student loans. This would seem to be a great time for financial services and other related firms to get creative and continue to stay involved with their customers to help them weather the storm.

Ernst \& Young surveyed consumer behaviour sentiment across five markets and tracked the spending habits, attitude towards COVID-19, data privacy and consumer trust. The study found that $42 \%$ of the consumers believe that their shopping will fundamentally change. Five consumer segments are likely to emerge in the post-pandemic scenario. These segments include "Keep cutting" (13.1\%), "Stay frugal" (21.7\%), "Get to normal" (31.4\%), "Cautiously extravagant" (24.7\%) and "Back with a bang" (9.1\%). These segments are arranged in order of their propensity to economize their purchasing due to pandemic on one end, and to resume normal pre-pandemic purchase and lifestyle on the other end. About two-third of the consumers may shift back to normal purchase soon after the pandemic while a few others who have experienced loss of employment of reduction of their incomes will economize on their purchasing. Marketers need to account for this shift in their strategy and need to develop the products and their marketing campaigns to accommodate these trends.

Nail (2020) advocates that in delivering the brand messages in the pandemic regime, the marketers should focus on three key areas. Firstly, they need to explain the brand precautions and ease out the fears with operational messaging on the expected consumer experience. Secondly, there is a need to reinforcing product value and its place during pandemic with brand messaging and thirdly they need to use empathy to enrich the brand image with value based messaging and positioning the brand as a source of comfort and reassurance. Such a strategy will contribute to better brand building in the post pandemic scenario. McKinsey study by Arora et.al (2020) finds that pandemic is changing the consumer behaviour in at least six different ways, which the marketers need to adopt. Consumers adoption of digital platforms for shopping and entertainment in eight weeks of pandemic surpassed the adoption of last five years and acceptability of e-services has increased. With people working and staying at home, there is an increasing influence of home on entertainment and other such products under consumption. With greater community and neighborhood interaction local businesses are finding more preference and firms will have to manage hyperlocal engagement as a part of their strategy. Building trust and holding brands to higher standards is the key to success of the marketing strategy in the post-pandemic scenario.

\section{To Sum Up}

Pandemic has given a halt to the fast moving life and its consequent hedonistic consumption behaviour. It has induced introspection and generated some thoughts for answering the very basic questions of human behaviour and existence, which we had left far behind in the rat race of materialism. This paradigm shift has happened with everyone and the academics and the consumer research is a part of this whole process. Marketing strategy needs to understand this basic shift in consumer thinking and behaviour, which is here to stay, at least for a few more years until the economy gains the momentum again. Technology 
driven marketing strategies, focused on value delivery are likely to be far more successful than bias for skimming and differentiation. To achieve this, then entire corporate strategy encompassing the product design, operations, pricing and value delivery have to work in unison. There is an opportunity for the local businesses to realign themselves and dwell upon the present positive consumer sentiment to establish themselves into the marketplaces. Hopefully, the new normal can contribute to a more inclusive distribution of wealth and a happier world to live in.

\section{References}

Accenture Research Report (2020) COVID-19: How Consumer Behaviour will be Changed, https://www.accenture.com/us - en/insight s/consum er-goods-services/coronavirus-consumerbehavior-research Accessed on 7th December, 2020.

Arora Arun, Hazan Eric, Dahlstrom Peter, Khan Hamza, Khanna Rock (2020) Reimagining Marketing in the Next Normal, Accessed online on 8th December, 2020 at https://www.mckinsey.com/business-functions/marketing-and-sales/our-insights/reimaginingmarketing-in-the-next-normal

Ernst and Young (2020) Four consumer behavior trends emerge during the COVID-19 pandemic, the first EY Future Consumer Index finds, Accessed online on 8th December, 2020 at https://www.prnewswire.com/news - releases/four-consumer-behavior-trends-emerged u ring - th e - covid - 19 - pande m ic-the-first-ey-future-consumer-indexfinds-301045840.html

Fahmy, Tarek \& Sohani, Armin (2020) The impact of a pandemic on brand preference in purchasing decisions of food and hygiene products: a COVID-19 perspective, Masters Thesis in Business Administration, Faculty of Business, Hogskolan Kristianstad, Accessed online on 8th December, 2020 at https://www.diva-portal.org/smash/get/diva2:1444267/FULLTEXT01.pdf

Lee, Jaime (2020) Consumer Behaviour: 13 Post Pandemic Trends to Watch, Accessed online on 8th December, 2020 at https://www.adroll.com/blog/marketing/consumer-behavior-13-post-pandemictrends-to-watch

Mehta, S., Saxena, T., \& Purohit, N. (2020). The New Consumer Behaviour Paradigm amid COVID-19: Permanent or Transient? Journal of Health Management, 22(2), 291-301. https://doi.org/ 10.1177/0972063420940834

Nail, Jim (2020) B2C Marketers: Use Your Brand Messaging To Deliver Value During The Pandemic, Accessed online on 8th December, 2020 at https://go.forrester.com/blogs/b2c-marketers-use-yourbrand-messaging-to-deliver-value-during-the-pandemic

Schachinger, Lindsay (2020) Consumer Trends to Stay Aware of During and After the COVID-19 Pandemic, Accessed online on 8th December, 2020 at https://www.cr$\mathrm{research}$. com/b log/con s u m er-trends-stay-aware-during-and-after-co vid-19-pandemic

Verma, Surabhi, Gustafsson, Anders (2020) Investigating the emerging COVID-19 research trends in the field of business and management: A bibliometric analysis approach, Journal of Business Research, Volume 118, Pages 253-261, ISSN 0148-2963, https://doi.org/10.1016/j.jbusres.2020.06.057 


\section{SKYLINE BUSINESS JOURNAL}

(ISSN 1998-3425)

\section{Call for Papers}

Submission deadline: 15 July 2021

Publication in December 2021

Skyline Business Journal (SBJ) invites original papers / management case studies / book reviews from academicians and practitioners on management, business, tourism, finance, human resource management, information systems, marketing and organizational issues. Contributions based on theoretical / empirical research or experience should illustrate the practical applicability and or the policy implications of the work described. The journal broadly covers all domains of management such as:

Global Business Strategy

Accounting and Finance

Marketing Management

Human Resource Management

Organizational Behavior

Operations Management
Project Management

Innovation and Entrepreneurship

Logistics and Supply Chain Management

Business Communication

Economics

Tourism and Hospitality

\section{Instructions for the Author}

1. Electronic Copy: Authors are required to submit an electronic copy (soft copy) of the papers in MS-WORD format (.Doc format) via email to sbj@skylineuniversity.ac.ae. A single article (including charts, diagrams and pictures etc.,) should not exceed six thousand words. Times New Roman -Font size 12- to be used to type the manuscript.

2. Mailing Address: Complete mailing address along with telephone and e-mail address should be given.

3. Cover Page: The first cover page shall contain the title of the manuscript, the author's name, and affiliation including acknowledgement, if any. This page will be removed before the manuscript is sent to a referee. The first page of text should show the title but NOT the author's name.

4. Abstract and Keywords: Each manuscript should include an abstract of about 100-150 words. Key words used in the paper should also be given.

5. References: References must be typed on a separate page, double-spaced, at the end of the paper. American Psychological Association's (APA) referencing method should be followed.

\section{Articles referred should be cited as follows:}

Swann, W.B.,Jr., Milton, L.P., \& Polzer, J.T. (2000). Should we create a niche or fall in line? Identity negotiation and small group effectiveness. Journal of Personality and Social Psychology, 79: 238-250

\section{Books referred should be cited as follows:}

Swann, W.B., Jr., Rentfrow, P.J \& Guinn, J.S. (2002). Self-verification: The search for coherence. In M.Leary \& J.Tagney (Eds.,). Handbook of self and identity: 367-383. New York: Guilford Press. 
6. Main Conclusions: The article should end with a non-technical summary statement of the main conclusions. Lengthy mathematical proofs and very extensive detailed tables should be placed in appendix or omitted entirely. The author should make every effort to explain the meaning of mathematical proofs.

7. Tables: Please check that your text contains a reference to each table. Type each table on a separate page. Authors must check tables to be sure that amounts add up to the totals shown and that the title, column headings, and captions are clear and to the point.

9. Equations: All but very short mathematical expressions should be displayed on a separate line and centered. Equations must be numbered consecutively on the right margin, using Arabic numerals in parentheses.

10. Clarity and Consistency: Please check your manuscript for clarity, grammar spellings, punctuation, and consistency of references to minimize editorial changes.

11. Submission Fees: There is no fee for publication of articles.

12. Submission Deadline: Articles should be submitted before 15th July of every year for publication in the annual issue.

13. Editing: SBJ reserves the right of making editorial amendments in the final draft of the manuscript to suit the requirement of the journal.

14. Copyright: SBJ will have the copyright of all the materials accepted for publication. Wherever copyrighted material is used, the authors should be accurate in reproduction and obtain permission from copyright holders, if necessary. Articles published in SBJ should not be reproduced or reprinted in any form either in full or in part without prior written permission from the Editor-in-Chief.

15. A management case study contains a description of real-life management issues and proposed solutions, at the strategic, functional or operational level.

16. Book Reviews: Book Reviews cover review of current book on business.

17. Complimentary Copy: A free copy of the Journal will be mailed to the author whose article is published.

Please submit your research papers to: sbj@skylineuniversity.ac.ae

\section{Skyline Business Journal is Indexed in:}
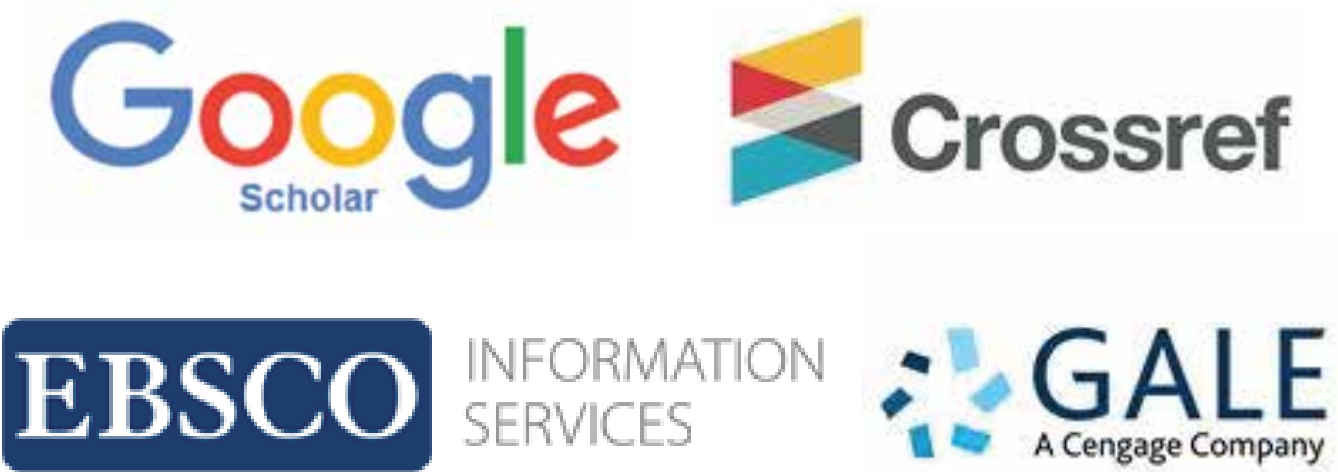